\begin{abstract}
UNIVERSIDADE DE SÃO PAULO
FACULDADE DE FILOSOFIA, LETRAS E CIÊNCIAS HUMANAS

DEPARTAMENTO DE GEOGRAFIA

PROGRAMA DE PÓS-GRADUAÇÃO EM GEOGRAFIA HUMANA
\end{abstract}

LORENA FRANCISCO DE SOUZA

MIGRAÇÃO PARA QUALIFICAÇÃO DA FORÇA DE TRABALHO E A QUESTÃO RACIAL:

ESTUDANTES AFRICANOS/AS LUSÓFONOS/AS NEGROS/AS EM UNIVERSIDADES GOIANAS 
LORENA FRANCISCO DE SOUZA

\title{
MIGRAÇÃO PARA QUALIFICAÇÃO DA FORÇA DE TRABALHO E A QUESTÃO RACIAL: \\ ESTUDANTES AFRICANOS/AS LUSÓFONOS/AS NEGROS/AS EM UNIVERSIDADES GOIANAS
}

\begin{abstract}
Tese de doutorado apresentada ao Departamento de Geografia da Faculdade de Filosofia, Letras e Ciências Humanas da Universidade de São Paulo sob a orientação do Prof. Dr. Heinz Dieter Heidemann
\end{abstract}


SOUZA, Lorena Francisco de. Migração para qualificação da força de trabalho e a questão racial: estudantes africanos/as lusófonos/as negros/as em universidades goianas. Tese Apresentada ao Programa de Pós-Graduação em Geografia da Faculdade de Filosofia, Letras e Ciências Humanas da Universidade de São Paulo, área de concentração Geografia Humana, para obtenção do título de doutor

APROVADO EM:

Banca Examinadora

Presidente da Banca

Titular 1

Titular 2

Titular 3

Titular 4

São Paulo

2014 
À Minha família 


\section{AGRADECIMENTOS}

Agradeço ao meu (des)orientador Prof. Dieter Heidemann pela paciência e sensibilidade, pelas dúvidas que instalou, as quais permaneceram como certezas de que nada sabemos.

Aos estudantes entrevistados pela disponibilidade, atenção e amizade.

Ao CNPq pela concessão da bolsa para a viabilização deste estudo.

Aos/às amigos/as de coração por todo apoio e incentivo.

À minha família: Wilson e Vera, Vinicius e Sofia, Clara, Luciana e Nildisnei. Sem eles nada teria acontecido. 
Sua dúvida pode tornar-se uma qualidade se o senhor a educar. Deve-se transformar em saber, em crítica. Cada vez que ela lhe quiser estragar uma coisa, pergunte-lhe por que aquilo é feio. Peça-lhe provas, examine-a; talvez a ache indecisa e embaraçada, talvez revoltada. Mas não ceda, exija argumentos. Ponha-se a agir assim, atenta $e$ consequentemente, cada vez, e dia virá em que, de destruidora, ela se tornará sua melhor colaboradora, talvez a mais sábia de quantas cooperam na construção de sua vida.

Rainer Maria Rilke, 1904. 


\section{RESUMO}

Esta pesquisa propôs uma análise crítica das migrações estudantis na atual sociedade moderna produtora de mercadorias, problematizando a vinda de estudantes africanos/as para as universidades brasileiras, em particular, a Universidade Federal de Goiás (UFG), a Pontifícia Universidade Católica de Goiás (PUC-GO) e a Universidade Estadual de Goiás (UEG) a partir do Programa de Estudante Convênio de Graduação e Pós-Graduação (PEC-G e PG). Este programa destaca-se como um importante acordo de cooperação educacional estabelecido entre o Brasil e países do Terceiro Mundo, dentre eles, os países africanos de língua portuguesa. Investigamos e propomos uma discussão sobre o/a migrante estudante africano/a, sob a base da qualificação da força de trabalho e o valor-dissociação como prerrogativas para a crítica do valor a partir da questão racial como uma particularidade. Na crise vivida pela sociedade moderna a mobilidade estudantil é encarada como uma alternativa governamental para o chamado desenvolvimento econômico e político de um Estado, portanto, a migração estudantil é um fenômeno particular de mobilidade da força de trabalho gerada pelo processo de modernização. A mobilidade de estudantes entre os países em desenvolvimento tem sido uma realidade cada vez mais presente e incitou-nos a pensar no migrante pela ótica dos acordos internacionais, a corrida pela qualificação profissional que se torna uma exigência fundamental no sistema produtor de mercadorias. Refletimos sobre a atual conjuntura em que se insere o/a migrante na condição de temporário/a, de futura mão-de-obra qualificada, como é o caso do/a estudante migrante. Por meio de revisão bibliográfica sobre a temática, coleta de dados em órgãos oficiais, nas universidades de destino sobre migrantes estudantes africanos/as e entrevistas com os/as mesmos/as, discutimos a representação social dos/as migrantes africanos/as na terra de "destino", e as consequências do racismo, tratados/as "estrangeiros/as não-desejados/as" ou "não-aceitos/as" ou africanos/as num sentido generalizado, preconceituoso e discriminatório.

PALAVRAS-CHAVE: Mobilidade do Trabalho, Educação, Migração, estudantes, África, Brasil 


\begin{abstract}
This research proposes a critical analysis of student migration in the current modern society produces of merchandise, discussing the coming of African students for the Brazilian universities, in particular, the Federal University of Goiás (UFG), the Pontificia Catholic University of Goiás (PUC -GO) and the State University of Goiás (UEG) from the program of Student Agreement Undergraduate and Postgraduate (PEC-G and PG). This program stands out as an important educational cooperation agreement established between Brazil and Third World countries, among them the African Portuguese-speaking countries. We investigate and propose a discussion about the African migrant student, under the base of the qualification of the labor force and value-dissociation and prerogatives to the critical value from the racial issue as a peculiarity. In modern society crisis, the student mobility is seen as a government alternative to the economic and political development of the State, therefore, the student migration is a particular phenomenon of mobility of the labor force generated by the modernization process. The mobility of students among developing countries has been an ever-present reality and encourages us to think of the migrant from the perspective of international agreements, and the race for qualification which becomes a key requirement in producer goods system. Reflect on the current situation in which the migrant is inserting on the temporary conditions, of the future qualified labor, such as the student migrant. Through literature review, collecting data from official agencies, on the universities destination for African migrants students and interviews with the same, we discussed the social representation of African migrants in the "destination" land, and the consequences of racism, treated as the not desire "foreign" or "not accepted" or African on generalized sense, prejudiced and discriminatory.
\end{abstract}

Key words: Labor Mobility. Education. Migration. Students. Africa. Brazil. 


\section{LISTAS DE ILUSTRAÇÕES}

\section{QUADROS}

\begin{tabular}{|lr|l|r|}
\hline $\begin{array}{l}\text { Quadro } \\
-\end{array}$ & 1 & Ranking do índice de estudantes africanos no Brasil (2000-2013) & 86 \\
\hline $\begin{array}{l}\text { Quadro } \\
-\end{array}$ & 2 & $\begin{array}{l}\text { Hotéis em Goiânia de acordo com o Manual do Estudante } \\
\text { Estrangeiro }\end{array}$ & 92 \\
\hline $\begin{array}{l}\text { Quadro } \\
-\end{array}$ & 3 & Aluguel em Goiânia conforme o Manual do Estudante Estrangeiro & 92 \\
\hline $\begin{array}{l}\text { Quadro } \\
-\end{array}$ & 4 & Transporte em Goiânia segundo o Manual do Estudante Estrangeiro & 93 \\
\hline $\begin{array}{l}\text { Quadro } \\
-\end{array}$ & 5 & $\begin{array}{l}\text { Custo de vida em Goiânia conforme o Manual do Estudante } \\
\text { Estrangeiro }\end{array}$ & 93 \\
\hline $\begin{array}{l}\text { Quadro } \\
-\end{array}$ & 6 & Candidatos Africanos Selecionados de 2000 a 2012 & 100 \\
\hline
\end{tabular}

GRÁFICOS

\begin{tabular}{|l|l|r|}
\hline Gráfico 1 - & Páis de Origem e IES dos/as Entrevistados/as & 21 \\
\hline Gráfico 2 - & $\begin{array}{l}\text { Discentes por área de conhecimento que ingressaram pelo PEC -G } \\
\text { na UFG de 1993 até 2010. }\end{array}$ & 81 \\
\hline Gráfico 3 - & $\begin{array}{l}\text { Indice de preferência por área de conhecimento de acordo com o } \\
\text { país do estudante PEC-G (UFG-2010) }\end{array}$ & 82 \\
\hline Gráfico 4 - & $\begin{array}{l}\text { Alunos selecionados por área do conhecimento pelo Programa de } \\
\text { Estudantes Convênio de graduação- PEC-G (UEG -2002 a 2010) }\end{array}$ & 82 \\
\hline Gráfico 5 - & $\begin{array}{l}\text { Preferência das áreas de conhecimento de acordo com o país do } \\
\text { estudante PEC-G (PUC-2010) }\end{array}$ \\
\hline Gráfico 6 - & $\begin{array}{l}\text { Área do Conhecimento dos cursos frequentados pelos/as } \\
\text { entrevistados/as }\end{array}$ \\
\hline Gráfico 7 - & Número de países por continente participantes do PEC-G e PG \\
\hline MAPAS
\end{tabular}

\begin{tabular}{|l|l|r|}
\hline Mapa 1 - & $\begin{array}{l}\text { Localização do Estado de Goiás em relação ao continente } \\
\text { africano }\end{array}$ & 24 \\
\hline Mapa 2 - & Países africanos participantes do PEC-G 2014 & 85 \\
\hline Mapa 3 - & $\begin{array}{l}\text { Número de ingressantes por países nas IES do Estado de } \\
\text { Goiás 2002/2011 }\end{array}$ & 87 \\
\hline Mapa 4 - & IES brasileiras participantes do PEC-G 2014 & 89 \\
\hline Mapa 5 - & Países africanos participantes do PEC-PG 2014 & 101 \\
\hline Mapa 6 - & UEG: localização das unidades universitárias & 108 \\
\hline Mapa 7 - & Número de migrantes estrangeiros por estado & 128 \\
\hline FIGURA &
\end{tabular}

Figura 1- $\quad$ Pichação de cunho racista e xenofóbica encontrada na UNESP de Araraquara em São Paulo 


\section{LISTAS DE ABREVIATURAS E SIGLAS}

\begin{tabular}{|l|l|}
\hline BRIC - & Brasil, Rússia, India, China \\
\hline CAPES - & Coordenação de Aperfeiçoamento de Pessoal de Nível Superior \\
\hline CELPE-Bras - & Certificado de Proficiência em Língua Portuguesa \\
\hline CNPq - & Conselho Nacional de Desenvolvimento Científico e Tecnológico \\
\hline CPLP - & Comunidade dos Países de Língua Portuguesa \\
\hline CSA - & Ciências Sociais Aplicadas \\
\hline IES - & Instituições de Ensino Superior \\
\hline IFES - & Instituição Federal de Ensino Superior \\
\hline INEP - & Instituto Nacional de Estudos e Pesquisas Educacionais \\
\hline LDB - & Lei de Diretrizes e Bases da Educação \\
\hline MEC - & Ministério da Educação e Cultura \\
\hline PALOP - & Países Africanos de Língua Oficial Portuguesa \\
\hline PEC-G - & Programa de Estudante Convênio de Graduação \\
\hline PEC-PG - & Programa de Estudante Convênio de Pós-Graduação \\
\hline PIB - & Produto Interno Bruto \\
\hline PIBIC - & Programa Institucional de Bolsas de Iniciação Científica \\
\hline PIBID - & Programa Institucional de Bolsas de Iniciação à Docência \\
\hline PIVIC - & Programa Institucional de Voluntários de Iniciação Científica \\
\hline PROCOM - & Pró-reitoria de Assuntos da Comunidade \\
\hline PROLICEN - & Programa Bolsas de Licenciatura \\
\hline PROMISAES - & Projeto Milton Santos de Acesso ao Ensino Superior \\
\hline PUC-GO - & Pontifícia Universidade Católica de Goiás \\
\hline RMG - & Região Metropolitana de Goiânia \\
\hline UEG - & Universidade Estadual de Goiás \\
\hline UFG - & Universidade Federal de Goiás \\
\hline
\end{tabular}




\section{SUMÁRIO}

\begin{tabular}{|c|c|}
\hline INTRODUÇÃO & 012 \\
\hline CONSIDERAÇÕES INICIAIS: NOTAS PARA A PARTIDA & 025 \\
\hline Sobre o processo de modernização e a valorização do valor como ponto de partida & 029 \\
\hline $\begin{array}{l}\text { CAPITULO I - A MOBILIDADE DO TRABALHO, A MIGRAÇÃO E A QUESTÃO } \\
\text { RACIAL NO CONTEXTO DA CRÍTICA DO VALOR-DISSOCIAÇÃO }\end{array}$ & 039 \\
\hline $\begin{array}{l}1.1 \text { O fenômeno migratório: uma compreensão crítica a partir da mobilidade do } \\
\text { trabalho }\end{array}$ & 039 \\
\hline 1.2 As migrações e o contexto da lógica do trabalho & 044 \\
\hline 1.3 Migrações, mobilidade do trabalho e mobilidade estudantil & 050 \\
\hline $\begin{array}{l}\text { 1.4 Migração e a questão racial: o racismo no processo de modernização em bases } \\
\text { da teoria do valor-dissociação }\end{array}$ & 057 \\
\hline $\begin{array}{l}\text { CAPÍTULO II - OS ACORDOS DE COOPERAÇÃO E A EDUCAÇÃO: DIÁLOGOS } \\
\text { POLÍTICOS ENTRE BRASIL E ÁFRICA A PARTIR DA MIGRAÇA ESTUDANTIL } \\
\text { COMO ESTRATÉGIA }\end{array}$ & 061 \\
\hline $\begin{array}{l}\text { 2.1 A África Lusófona no contexto da integração político-econômica ao mercado } \\
\text { mundial: fragilidades do processo de modernização retardatária }\end{array}$ & 061 \\
\hline 2.1.1 Brasil-África no contexto do mercado mundial & 066 \\
\hline $\begin{array}{l}2.2 \text { A Educação como mercadoria: qualificação da força de trabalho como } \\
\text { necessidade na sociedade atual }\end{array}$ & 070 \\
\hline $\begin{array}{l}\text { 2.3 O Programa de Estudantes - Convênio Graduação e Pós Graduação (PEC- } \\
\text { G/PEC-PG): cooperação educacional e a meta dos acordos e programas }\end{array}$ & 084 \\
\hline $\begin{array}{l}2.4 \text { O Centro-Oeste e a corrida pela qualificação: o caso de três universidades } \\
\text { goianas }\end{array}$ & 103 \\
\hline $\begin{array}{l}\text { CAPITULO III - O SUJEITO SUJEITADO DA MIGRAÇÃO ESTUDANTIL NA } \\
\text { MOBILIZAÇÃO PARA A QUALIFICAÇÃO DA FORÇA DE TRABALHO: O/A } \\
\text { ESTUDANTE AFRICANO/A, PERCEPÇÕES DE IDENTIDADE, RAÇA E } \\
\text { (CON)VIVÊNCIA COM O RACISMO OU COMPREENSÕES DA CONDIÇÃO DE } \\
\text { ESTRANGEIROS/AS E NEGROS/AS }\end{array}$ & 110 \\
\hline 3.1 Migrante e identidade: a provisoriedade e o pertencimento na mobilidade & 110 \\
\hline $\begin{array}{l}\text { 3.2 Identidade étnico-racial e migração: vivências do/a migrante estudante nas } \\
\text { universidades goianas }\end{array}$ & 119 \\
\hline CONSIDERAÇÕES PARA NÃO FINALIZAR & 151 \\
\hline REFERÉNCIAS & 154 \\
\hline APÊNDICE - Roteiro de entrevista & 167 \\
\hline ANEXO - Termo de responsabilidade financeira para inscrição no PEC & 169 \\
\hline
\end{tabular}




\section{INTRODUÇÃO}

Esta pesquisa corresponde a uma inquietação que nasceu durante e após o mestrado, quando trabalhamos as trajetórias socioespaciais de professoras negras em Goiânia, numa discussão sobre a questão do gênero e raça na geografia (SOUZA, 2007). A intenção foi partir de uma discussão acerca das trajetórias como um elemento que representa as relações sociais e raciais no espaço, no sentido de entender a mobilidade do trabalho, a migração, as relações de trabalho, o deslocamento espacial imbuído de representações sobre lugares, dimensões da vida cotidiana, o lazer e a cidade como lócus destas ações cotidianas.

No entanto, com o término desta dissertação, compreendemos a necessidade de aprofundamento de algumas categorias de análise que, até então, não haviam sido levantadas e ofereciam grandes possibilidades para pensar o processo de migração, bem como relaciona-lo com outras contribuições teóricas.

O intuito em (re)começar uma investigação acerca do fenômeno migratório consistia em retomar as dimensões alcançadas pela pesquisa feita anteriormente, no que tange à problemática social, racial e de gênero, relacionando as histórias de vida nas ligações entre migração, trabalho e qualificação da força de trabalho. Porém, à medida em que avançávamos nas leituras referentes à temática, buscamos delimitar um grupo social que também já permeava nossas reflexões acerca das relações raciais no Brasil e a experiência de estudantes africanos/as negros/as em universidades goianas. Assim, pautamo-nos, já na construção do projeto de doutorado, na compreensão sobre as consequências do processo de modernização na sociedade atual produtora de mercadorias, o mercado mundial e suas exigências em tempos de crise do trabalho, precarização das relações sociais, aguçamento da individualidade como elemento fundante da modernidade e a chamada mobilização do trabalho que culmina com o fenômeno migratório em diferentes escalas.

Nesse sentido, muitos foram os desafios para a construção de uma proposta de investigação nesta tese de doutoramento. De início as questões levantadas para dar corpo à investigação baseavam-se numa tentativa ainda distante de buscar compreender a singularidade como um espetáculo, no qual Débord (1997) já lembrava de que a vida das sociedades modernas se apresenta como uma imensa acumulação de espetáculos. Coube ultrapassar as discussões ainda frágeis sobre "o 
espetáculo das raças" (SCHWARCZ, 1993) num contexto em que o pano de fundo ainda não havia sido avistado de maneira crítica e contundente.

Aos poucos buscamos levantar as categorias que fundamentariam as dúvidas lançadas, no sentido de tratar a crítica fundamental do valor (KURZ, 2005) como a base na compreensão das migrações internacionais de estudantes africanos/as visando a qualificação da força de trabalho. Para isso, a tentativa foi de nos ater ao campo da qualificação, ao ensino/educação, à relação existente entre economia e cultura, entre formação profissional e força de trabalho, além de trazer a crítica do valor-dissociação que traz toda a dimensão social, racial e de gênero para o contexto da crítica ao moderno sistema produtor de mercadorias.

A problemática da migração estudantil africana no processo de modernização retardatária abarca as discussões que versam sobre a construção da identidade negra e das experiências coletivas nas interações políticas e culturais da chamada diáspora do Atlântico Negro (GILROY, 2001). A identidade racial se apresenta como um elemento presente na migração africana na medida em que traz a problemática racial para as relações sociais de vivência do/a migrante. A diáspora para Ratts (2010) produziu formas de organização política, culturais e religiosas além das fronteiras nacionais. Ela pode ser, portanto, uma

(...) ponte construída sobre o vácuo existente entre 0 imperativo de pertencimento nacional imposto pelo Estado moderno e, de outro lado, os discursos, a estética e a poética da exclusão (...)isto preserva o vinculo entre identidade e território enquanto reconhecimento (...) pelas práticas excludentes do Estado (HINTZEN, 2007, pp. 59).

A diáspora abarca construções coletivas que resistem à administração e controle do Estado. Para Gilroy (2001), ela "constrói esferas públicas alternativas, formas de consciência e de solidariedade comunitária que mantém a identificação fora do espaço/tempo nacional" (2001, p.251).

Hintzen (2007) também nos lembra da história de dependência dos Estados africanos, explorados, subordinados e expropriados, elementos vigentes da colonialidade, assim, "mesmo quando africanos controlam os aparatos do Estado, eles continuam a ser vistos a partir de termos historicistas de imaturidade, em contínua necessidade de tutelagem civilizatória do Norte" (2007, p. 59).

As contribuições teóricas sobre a formação/fortalecimento de territórios, pautada por Haesbaert (2009), tem pautado considerações acerca da condição 
migrante, os fenômenos de desterritorialização e reterritorialização e os equívocos lançados pela leitura do migrante como sujeito desterritorializado. Não é pelo fato de os/as migrantes saírem de seu território, no caso da migração internacional, que se tornam "desterritorializados" e perdem sua identidade.

Saïd (1990 apud HAESBAERT, 2009) nos lembra das geografias imaginativas e das (re)invenções dos grupos em diáspora na reconstituição de sua territorialização a nível cultural. As discussões acerca da (des)territorialização problematiza a condição social e as identidades étnico-culturais dos/as migrantes em questão, o que reflete um processo complexo e diferenciado intimamente ligado à camada social a que pertencem e aos grupos culturais nos quais se inserem, além de depender dos níveis de (des)vinculação dos mesmos com o território.

Para a discussão sobre a mobilidade estudantil africana, procuramos pontuar a crítica ao processo de modernização e a problemática racial a partir da crítica do valor-dissociação que dialoga com a compreensão das dimensões de raça e gênero como partícipes do modo como a sociedade cria mecanismos de individualização e desigualdades. Buscou-se, assim, compreender a noção de raça, assim como o é para Scholz (2011), como importante aspecto no fenômeno migratório estudantil africano, procurando repensar o método de investigação em que as variáveis raça, gênero e camadas sociais correspondem a um processo indissociável.

A partir deste momento, começamos a delimitar um dos maiores desafios desta reflexão, no sentido de problematizar a migração estudantil com recorte racial a partir da crítica fundamental do valor, enfatizando a teoria critica do valordissociação difundida por Scholz (2011). A teoria da dissociação e do valor parte do princípio, baseada, principalmente, em Marx, Lukács, Adorno e Postone, de que o trabalho abstrato e o valor constituem o principio base da sociedade capitalista; no entanto, numa forma modificada pela relação de dissociação de gênero. É a dissociação-valor que "constitui a base da sociedade capitalista na medida em que ela representa o duplo caráter do trabalho, o abstrato e o concreto que exprime 0 modo do tempo abstrato" (SCHOLZ, 1992, p.17).

A teoria do valor-dissociação possibilitou a reflexão sobre o conceito de fetiche e de dominação proveniente do capitalismo patriarcal. Entendemos esta teoria, como salienta Lamas (2011), enquanto princípio estrutural geral que atravessa todas as esferas. Segundo ele 
(...)a dissociação-valor insiste na reflexão dialética sobre a relação tensa entre a essência e a aparência, uma condição da crítica do fetichismo. Ao contrário das teorias pós-modernas que abandonam a distinção através de um anti-essencialismo superficial, a teoria da dissociação-valor defende a categoria de essência. Mas (e aqui está a chave) a essência não é positiva, trans-histórica ou biológica (a capacidade das mulheres darem à luz, por ex.) mas sim negativa, histórica e social, designadamente a essência fetichista da forma de riqueza moderna do valor e do trabalho abstrato. Nesse sentido, não se recusa também categorias teóricas universalistas, à boa maneira das teorias pós-modernas, antes denuncia-se 0 universalismo negativo e realmente existente do sistema mundial produtor de mercadorias (LAMAS, 2011, p.06).

Evidenciamos, nesse sentido, que a crítica do valor-dissociação procura aprofundar na crítica ao universalismo abstrato do sujeito monetário, concorrencial, masculino, branco e ocidental (KURZ, 2002). Para nós, no sentido de que esta teoria apresenta-se como pano de fundo para esta tese, confere-se ao fato de ela permitir pensar as diferenças na sua relação dialética com a totalidade social negativa, na negação da naturalidade das coisas, possibilitando também refletir simultaneamente as diferenças de raça, classe, gênero e etnia.

O conceito de dominação e a redução do sujeito pressupõe o entendimento de que a dominação é sem sujeito em sua essência, considerando também as reflexões de Oliveira, Moreira e Marques (2011) em que a corrida pelo dinheiro por si mesmo tornou-se a grande mola propulsora do moderno sistema produtor de mercadorias,

(...) inaugurando uma sociabilidade fundada sobre o domínio das coisas e sobre a dependência das pessoas. Uma relação social totalizadora cujos imperativos vão se impondo sobre as diferentes subjetividades humanas, impactando sobre seu caráter e sobre suas relações intersubjetivas (OLIVEIRA, MOREIRA E MARQUES, 2011, p.02).

Assim, se adentrarmos para além da aparência, o capital não funciona basicamente a partir da condição de classes e interesses pessoais/individuais. Ele impõe ao "sujeito" a necessidade de multiplicar o dinheiro no processo de valorização do valor e o/a trabalhador/a então vê-se na obrigação de se tornar sujeito mercadoria ou "sujeito sujeitado", reforçando sua existência social. Desse modo, tanto o capitalista quanto o/a trabalhador/a se reduzem a fantoches do Capital que se submetem ao processo de "dominação sem sujeito". (KURZ, 1993). 
Ainda no que tange à teoria do valor-dissociação é imprescindível afirmar que suas reflexões asseguram mais profundamente às questões que envolvem 0 patriarcado e a reflexão crítica da postura tradicional do marxismo em secundarizar as causas femininas/istas em detrimento das questões de "classe", ela compreende que a teoria do valor por si só não conseguirá captar a totalidade da sociedade da mercadoria enquanto omitir a importância do que o valor exclui e dispensa, ou seja, as categorias dissociáveis como gênero, raça e etnia (SCHOLZ, 1992).

Como nos lembra Lamas (2011) a "valorização do valor" é um processo social dinâmico e objetivo de intensidade histórica e expansividade geográfica. Torna-se um grande equívoco reduzir o capital, sua perversidade e seus agentes subjetivos a elementos menores, o que acaba trazendo um entendimento de que há sujeitos com vontades individuais e interesses próprios. Assim, compreendemos e afirmamos que a migração, antes de reduzir-se a uma vontade individual, como um aspecto privilegiado na concepção iluminista de sujeito moderno, pressupõe a sujeição à mercadoria.

A consideração do migrante como sujeito sujeitado apresenta-se como uma possibilidade analítica que complementa ou se justapõe às interpretações pósmodernas de sujeito que ontologizam as diferenças e reforçam somente as vontades individuais na ação de migrar enquanto o olhar sobre a mobilização para a qualificação da força de trabalho nos dá pistas ao entendimento de que há uma engrenagem densa que direciona os movimentos migratórios na sociedade moderna produtora de mercadorias.

Não se pretende aqui desconsiderar as contribuições das teorias póscoloniais e chamadas pós-modernas sobre o fenômeno migratório, inclusive elas fazem parte de nossas leituras e contribuem para a compreensão da diáspora e cultura africana no mundo e a construção da identidade negra, mas sim, compreender a sociedade atual na ditadura da economia de mercado que vai, assim, além das escolhas subjetivas de cada indivíduo.

Ao conversarmos com os/as estudantes africanos/as, há concepções de que morar no Brasil, estudar no Brasil tornou-se uma "alternativa" quase obrigatória ou o que Gaudemar (1977) considera como liberdade negativa numa mobilização forçada, pois estamos falando de países de um continente que, historicamente, alimentaram a engrenagem da acumulação primitiva, servindo às metrópoles como produtores de matérias-primas e jogados ao processo de modernização retardatária 
e ao violento processo de acumulação primitiva. Partimos do entendimento de que o/a migrante é um protagonista social e cultural "sujeito sujeitado a uma organização econômica e social que determina os comportamentos e as atuações do migrante" (HEIDEMANN, 1998, p.17).

Frisamos que o valor-dissociação (ou também chamada de valor-cisão) é elemento importante para entender o eurocentrismo do poder mundial capitalista, da divisão mundial do trabalho e da troca (QUIJANO, 2007). Como resultado da dominação colonial moderna, as considerações sobre a raça permeiam todos os âmbitos do poder mundial capitalista. Segundo Quijano (2007) o eixo central das formas de dominação social e exploração do trabalho foi a associação entre a mercantilização da força de trabalho e a hierarquização da população mundial em termos de raça e de gênero.

Cabe salientar nossa preocupação em levantar importantes contribuições das ciências sociais no que tange à análise sobre o fenômeno migratório, diversas experiências foram consideradas neste trabalho, no entanto, buscamos sair da condição descritiva do fenômeno e das narrativas do/a migrante como um fim em si mesmo.

Não é possível considerarmos todos/as os/as migrantes como iguais, desconsiderando as variáveis de classe, raça, gênero e idade, pois a mobilidade de pessoas apresenta-se como um fenômeno complexo e atinge diferentemente um indivíduo de acordo com essas categorias. Nesse sentido, é que pautamos na compreensão sobre as particularidades numa universalidade negativa e não a uma singularidade que percebe o fenômeno por si mesmo. A particularidade em si nos obriga a ver a totalidade e suas contradições e não a soma de partes. (KURZ, 1992) Fazendo essa consideração, lançamos alguns questionamentos que conduziram a pesquisa inicialmente acerca da mobilidade do trabalho "aplicada" aos/às estudantes africanos/as. Como pensa-los, do ponto de vista da condição migrante? Como se configuram as relações Brasil e Estados lusoafricanos a partir do Programa de Estudante Convênio de Graduação e Pós-Graduação (PEC-G e PG)?

Do ponto de vista cultural e racial, não há dúvidas de que o/a migrante negro/a, embora estudante, seja indesejado ou discriminado no Brasil por conta da condição histórica do continente africano e pelas consequências do racismo moderno. A impressão é que estas questões podem despertar uma elaboração atenta sem perder de vista o intuito de crítica ao fenômeno migratório a partir da 
dissociação-valor, mas compreendendo que os sujeitos em questão têm uma percepção generalizada de servir em benefício da família ou do Estado/país. Não se trata também de desconsiderar as impressões individuais, mas considerar a análise destes indivíduos nas suas particularidades enquanto sujeitos sujeitados.

No que se refere ao entendimento da educação no mundo da mercadoria, o que tem chamado a atenção é a crítica de Kurz (2004), em seu texto "Analfabetos secundários" que relembra a história colonialista do Ocidente pautada no ideal de civilização superior europeu. Este ideal circundava aspectos técnicos, econômicos e culturais. Durante todo o século XIX e XX tomaram corpo e se alastraram as ideologias eurocêntricas. Porém, após a Segunda Guerra vê-se uma inversão ideológica e o que antes tratava-se de um princípio incontestável de superioridade e avanço - a raiz eurocêntrica - passa a ser questionado e fortalece-se o reconhecimento de padrões culturais externos ou estrangeiros.

No entanto, o processo de "descolonização" não culminou com a ruptura de ações e posturas opostas a serem lideradas pelos movimentos sociais pós-coloniais em países de passado colonialista. Este não rompimento é facilmente perceptível quando nos remetemos à busca daqueles pela construção dos ideais de nação e civilização. Como consequência, o autor nos faz retomar a problemática educacional nos países colonizados que também perpassam por ideais ocidentais, impedindo o surgimento de uma emancipação sociocoletiva que edifique a independência política e cultural do pólo subjugado.

Do ponto de vista interno, no núcleo duro da civilização ocidental, a educação representa, como se pensa, um elemento sine qua non do progresso, é a formação do sujeito sujeitado, o disciplinamento, a adequação às regras sociais. Ela não pode ser símbolo da emancipação, pois representa nada mais que um endogâmico processo civilizatório em que o indivíduo pode vir a se tornar "material" de valorização capitalista.

Com seu caráter disciplinador e violento, a educação foi um referencial-chave para consolidar o trabalho. Ao mesmo tempo, foram criadas maneiras diferenciadas de educar as camadas abastadas que, como princípio, deveriam reproduzir a condição de classe. Essa educação elitista se restringiu ao funcionalismo instrutivo e, na era pós-colonial, viu-se a reprodução dos ideais de educação funcionalista, para amplas partes da população, cada uma com suas particularidades. 
Embora estes modelos de educação tenham sido adotados pelos países do chamado "Terceiro Mundo", é preciso pontuar as transformações ocorridas no campo educacional diante da crise mundial advinda da Terceira Revolução Industrial que caracterizou o sistema moderno contemporâneo de escolas e universidades no mundo todo, atingindo consideravelmente a estrutura educacional dos países terceiro-mundistas.

Neste processo atual de transformação da educação, iniciou-se a necessidade de internacionalização do ensino, mais precisamente, sobre o ensino superior, no qual os estudantes africanos sujeitos desta pesquisa se inserem. Neste aspecto, a pesquisa também se objetivou analisar as suas impressões sobre o viver no Brasil, sobre a condição migrante, estrangeira e negra que assola, muitas vezes, as situações cotidianas na universidade, em casa, na rua, na cidade. A maneira como a sociedade enxerga esses estudantes é crucial para o entendimento de que, como reflexo eurocêntrico de qualidade e progresso, ser estudante negro africano ainda é vivenciar o racismo e os estereótipos forjados para a propagação de uma imagem do continente africano, repleto de fragilidades nos aspectos econômico, político e cultural, ávido por desenvolvimento e pela corrida ao alcance do chamado progresso.

Tratar sobre a migração estudantil requer percorrer caminhos ainda pouco "pisados" e conhecidos na Geografia. Estudos mais voltados para a discussão das territorialidades, (des)territorializações e redes têm sido ricos para a análise sobre o fenômeno migratório.

Mediante uma reflexão sobre o caráter da migração temporária atinente ao estudante africano no Brasil cabe apresentar melhor o grupo social partícipe dessa pesquisa. A intenção desta pesquisa não culminou na descrição etnográfica dos passos e vivências dos/as estudantes entrevistados/as por entendermos que a proximidade do pesquisador para este fim responde a um intenso trabalho de convivência e, quando até mesmo, pertencente a tal grupo social um nãodistanciamento da crença nos motivos pessoais que o levou a migrar.

Nossa intenção foi trazer elementos que "conversam" com as decisões pessoais de migrar, como a busca pelo pano de fundo que rege as migrações como um todo, em especial, a estudantil, no sentido de vermos que a qualificação da força de trabalho ou o ingresso no ensino superior para jovens africanos/as corresponde a 
uma das armas modernas de aumento do poder econômico e do esperado "desenvolvimento" sociopolítico.

No decorrer da pesquisa, foram lançadas impressões diante das perguntas feitas, diante dos encontros realizados, como por exemplo, na questão sobre a nãoparticipação da comunidade acadêmica brasileira em momentos organizados pelos estudantes africanos - principalmente, os acadêmicos -- ou no sentido de uma busca pela afirmação da diferença no universo dentro e fora da academia em que brasileiros/as não participam.

Foram realizadas entrevistas a partir de um roteiro estruturado e importantes conversas e diálogos abertos, versando, principalmente, sobre a condição de estudante no Brasil e as impressões/ representações e vivência no país, a "escolha" pelo Brasil, os cursos procurados e oferecidos pelas instituições de destino, os financiamentos disponíveis que os mantêm (ou não) na universidade.

Foram 17 estudantes, sendo 11 (dez) homens e 06 (seis) mulheres com idade entre 18 (dezoito) e 29 (vinte e nove) anos, num total de 55 estudantes nas universidades goianas em destaque nesta pesquisa no período de 2002 a 2011 . A escolha obedeceu, várias vezes, as redes de conhecidos pela universidade e, durante encontros referentes e promovidos pelos movimentos sociais negros em Goiânia, houve a possibilidade de diálogo com alguns deles.

Nas questões elaboradas, discutiu-se o entendimento dos/as estudantes a respeito do Programa Estudante-Convênio (PEC-G e PG), sobre o funcionamento do programa, das obrigatoriedades estabelecidas desde o processo seletivo, das relações com a universidade de acolhida, das impressões sobre o Brasil e a cidade de acolhida, além das compreensões sobre a condição de estrangeiro/a negro/a

Durante as entrevistas e nas conversas buscamos problematizar a sua condição de negros/as e de que forma isso poderia torna-los particulares da condição de estrangeiros/as. As duas categorias, migrante e negro/a, reforçam que a etnicidade, comentada por Martes (2003), destaca-se como um elemento de reconhecimento do outro em que os/as brasileiros consideram de maneira genérica o africano. Muitos chegaram a comentar que só se reconheceram enquanto negros/as após a chegada ao Brasil e que percebem que mesmo o negro brasileiro migrante é inferiorizado na sociedade em que vive.

Dos 17 entrevistados, 09 (nove) estudam na Universidade Federal de Goiás (UFG), 06 (seis) na Pontifícia Universidade Católica (PUC-GO) e 02 (dois) na 
Universidade Estadual de Goiás (UEG), sendo 07 (sete) de Guiné Bissau, 05 (cinco) de Angola, 01 (um) de Moçambique, 04 (quatro) de Cabo Verde. Dos estudantes da UFG 02 (dois) moram na Casa do Estudante Universitário de propriedade da universidade enquanto 07 (sete) moram de aluguel em apartamentos/quitinetes. Dentre os da PUC-GO 04 (quatro) moram na Casa do Estudante e 02 (dois) moram em apartamentos/kitinetes alugados em que dividem a moradia entre si. Os dois estudantes da UEG moram de aluguel e dividem as despesas com outros colegas. Os cursos que frequentam são Jornalismo, Biomedicina, Ecologia e Análise Ambiental, Engenharia Civil, Publicidade e Propaganda, Letras, Odontologia, Enfermagem, Engenharia da Computação, Fisioterapia e Nutrição e Pós-Graduação em Geografia e em Letras, conforme mostra (gráfico 1). Importante salientar que alguns estudantes não quiseram ceder entrevistas, apesar da insistência, portanto, foi respeitada a disponibilidade e a disposição de cada um/a.

Gráfico 1 - País de Origem e IES dos/as Entrevistados/as

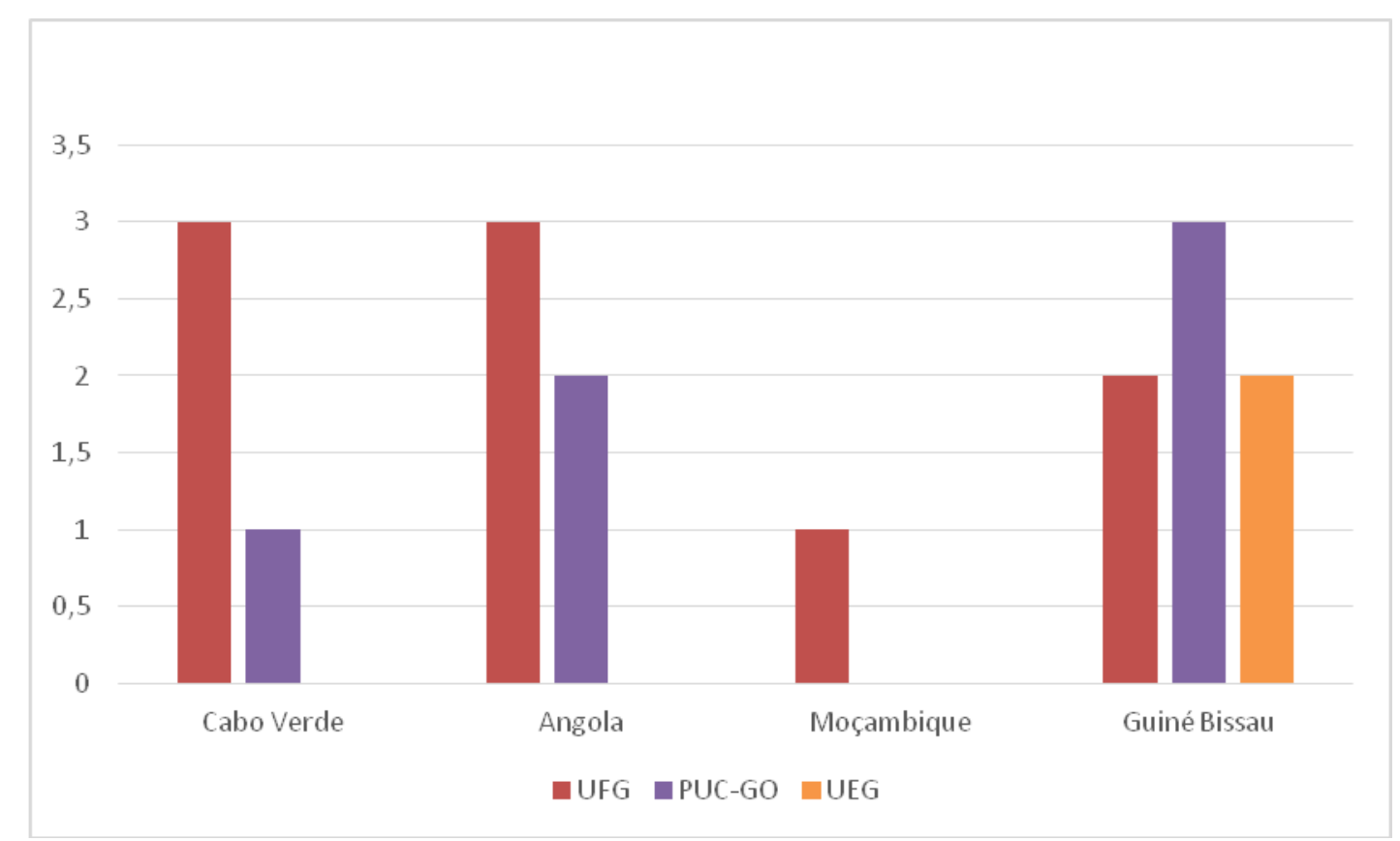

Fonte: Entrevista, 2010.

Alguns encontros/entrevistas aconteceram nas casas dos estudantes (não somente na Casa do Estudante), outros nas respectivas universidades, em locais de lazer e eventos dentro e fora das universidades, para conhecer melhor o cotidiano deles/as e que a migração não se refere apenas ao deslocamento físico, mas envolve questões políticas, econômicas, sociais e culturais e a interação das esferas 
individual e coletiva, a subjetividade e a dimensão estrutural do processo migratório (TANNURI, 2010).

Os jovens estudantes migrantes estão envolvidos nessa trama estrutural da dinâmica migratória, muitas vezes, sem perceberem que correspondem a elementos de uma engrenagem em que a valorização do valor como um fim em si mesmo, reproduzindo a relação sujeito e trabalho na razão fetichizada. Vale lembrar que, como alerta Heidemann (2010), o/a pesquisador/a de migrações também pode cair na armadilha da naturalização do histórico e do social que circunda o/a migrante.

Portanto, o/a pesquisador/a das migrações não pode/deve se limitar à aparência da ação voluntária, na qual o/a migrante busca satisfazer o seu interesse individual, desconsiderando que a qualificação da força de trabalho é uma demanda do sistema atual e, para os Estados-nações atingidos pela modernização retardatária, cabe cumprir este papel de maneira urgente e o migrante sujeitado a essas exigências insere-se num processo simbólico também de violência, seja enquanto estrangeiro/a, enquanto migrante e enquanto negro/a, aspectos que salientamos aqui como fundamental para a problematização da vinda de estudantes africanos/as negros/as num país que propagandeia a democracia racial.

Foram contactadas as assessorias de relações internacionais das três universidades em foco, a Universidade Federal de Goiás, a Pontifícia Universidade Católica de Goiás e a Universidade Estadual de Goiás, além de serem coletados dados documentais, em contatos diretos ou em consulta a sítios oficiais das universidades, referentes ao contingente dos estudantes do PEC-G e PEC-PG em Pró-reitorias de Graduação, a relação de alunos por curso e por área de conhecimento, bem como informações a respeito de assistência e orientação informativa aos estudantes.

Algumas informações foram transmitidas por servidores técnicoadministrativos, pessoalmente e via e-mail, por estudantes brasileiros/as próximos/as aos/às estudantes africanos/as. Nos sítios do Ministério das Relações Exteriores foram conseguidas informações a respeito da regulamentação do programa PEC-G e PG, decretos, orientações e procedimentos a serem seguidos aos estudantes, estatística de ingressantes, concluintes e pós-graduandos e as instituições participantes.

O mapa 1 a seguir nos mostra, a título de localização, a referência espacial do Estado de Goiás e da cidade de Goiânia. As universidades goianas têm cada vez 
mais investido em programas que dêem destaque em termos de ensino, pesquisa e extensão e, com 0 acelerado processo de urbanização, as transformações econômicas provenientes do processo de modernização, tem havido um interesse político considerável para equiparar o ensino superior goiano com universidades mais consolidadas e renomadas, principalmente da região Sudeste.

O desenvolvimento e a qualidade de vida são fatores de destaque no discurso do chamado planejamento como estratégia para a valorização do Estado de Goiás e, principalmente, para a Região Metropolitana de Goiânia (RMG). Para Arrais (2007), intensificam-se os setores do comércio e serviços - não acessível a todos conforme as contradições do discurso desenvolvimentista - portanto,

(...) a condição de centralidade de Goiânia, seja em relação ao Estado ou mesmo à RMG, tem sido apontada como fator de competitividade. A qualidade de vida, nesta argumentação, relaciona-se à maior renda e oferta de equipamentos de consumo coletivo, típicos de uma capital de Estado. Entretanto, essa oferta concentra-se em Goiânia, o que dificulta o acesso aos habitantes dos bairros e municípios periféricos (ARRAIS, 2007, p.12).

Desse modo, podemos aferir que a consolidação de universidades e aumento de universidades no Estado e na RMG significa que o ensino superior também corresponde a um serviço que tem sido oferecido para valorizar a região e divulgar o enriquecimento e o "progresso" de Goiânia como cidade universitária, atrativo para estudantes brasileiros e estrangeiros, financiadores de pesquisa, empresas multinacionais, incentivo federal para o aumento do número de vagas e programas de cooperação educacional. 
LOCALIZAÇÃO DO ESTADO DE GOIÁS EM RELAÇÃO AO CONTINENTE AFRICANO

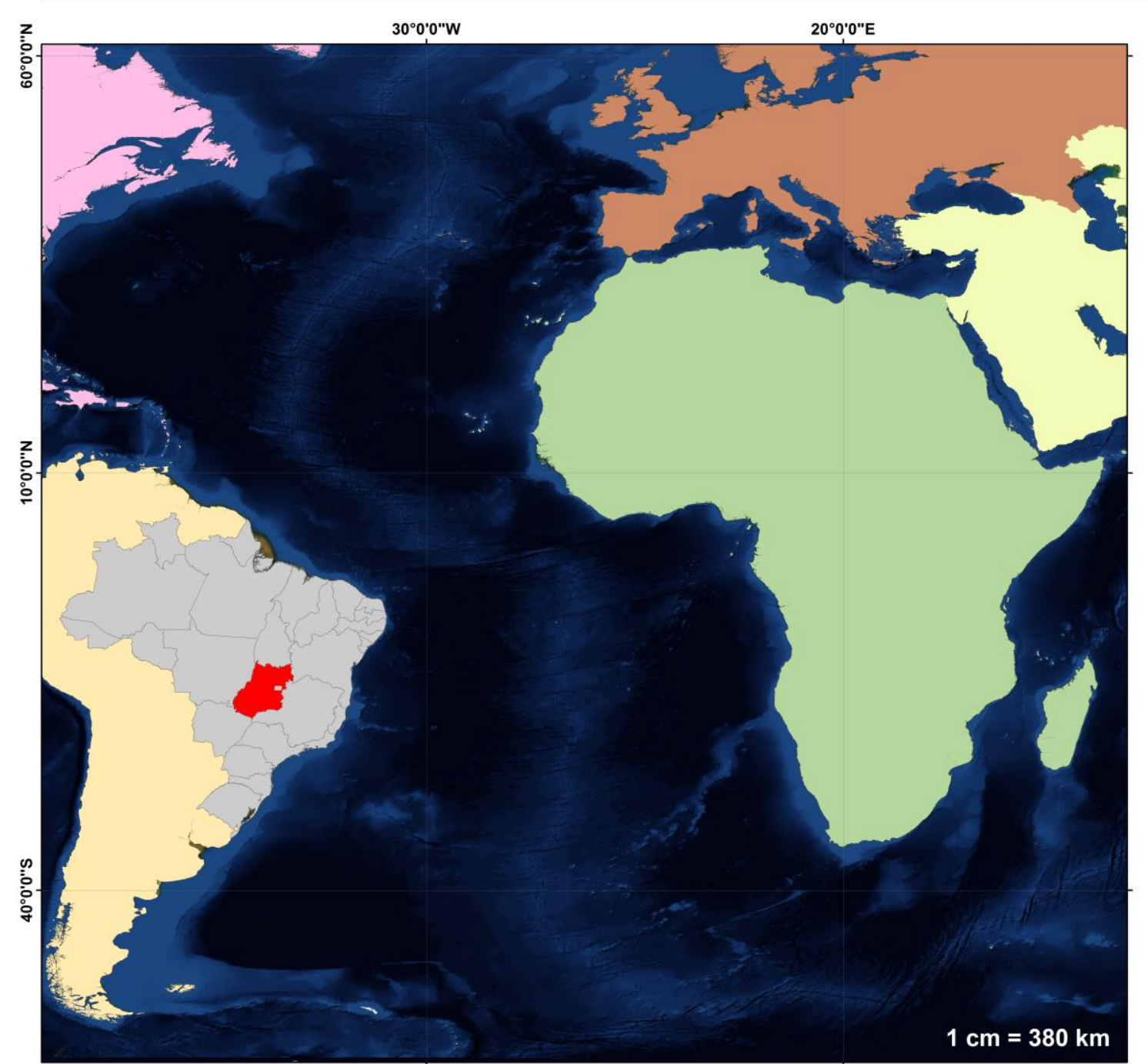

\section{Legenda}

Brasil

Estado de Goiás

Continentes

África

Ásia

Europa

América do Norte

América do Sul

\section{Fonte: ArcGis On-line}

Elaboração: MS. Vinicius Gomes de Aguiar

Data de Produção: 24 de Outubro de 2011

曾

\begin{tabular}{rrrr}
$0 \quad 5001.000$ & 2.000 & 3.000 & 4.000 \\
\hline & & \\
\hline
\end{tabular}

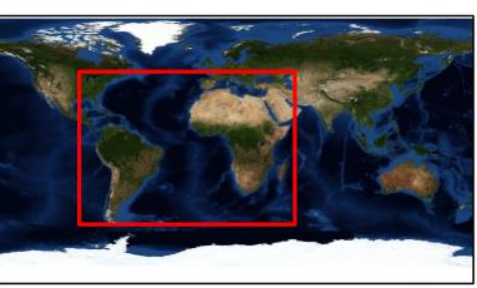




\section{CONSIDERAÇÕES INICIAIS: NOTAS PARA A PARTIDA}

Nossa investigação acerca do fenômeno migratório no processo atual de modernização, o qual vive a sociedade, tem como um de seus principais fundamentos a análise crítica sobre um grupo social em questão que corresponde a uma modalidade de migração. A migração para qualificação da força de trabalho é uma realidade cada vez mais presente entre ex-países colonizados e nosso olhar adentra-se para a discussão sobre este grupo social e nas diversas maneiras de ele (re)configurar-se/estabelecer-se num outro território nacional.

É necessária uma discussão da atual conjuntura econômica, perpassando, no entanto, as bases que a fundamentaram e construiu uma sociedade forjada no ideal de desenvolvimento e na fetichização das relações humanas e as de produção, dando força à condição de barbárie da sociedade atual. Neste enfoque é que disporemos de reflexão e análise crítica sobre as migrações de estudantes africanos para o Brasil.

Consideramos que os deslocamentos migratórios são realizados por uma coletividade. O/a migrante é fetichizado, mas não passivo no contexto da mobilidade espacial, porém não é o único agente, como se o deslocamento representasse somente uma vontade individual e aventureira (PÓVOA NETO; FERREIRA, 2005).

Para tratarmos desse objetivo e lançar as bases para a crítica à migração de estudantes africanos para o Brasil, consideramos de suma importância o destaque para algumas temáticas/temas de estudo para entender a migração, como o processo de modernização, mobilidade, migração, raça e a qualificação.

Nossa preocupação, para embasar nossa investigação, consiste no entendimento crítico das relações engendradas no moderno sistema produtor de mercadorias, sendo, portanto, imprescindível salientar o processo de modernização e suas contradições. Ao remetermos aos países do continente africano ou, mais genericamente, aos países ditos do Terceiro Mundo, fica evidente que o processo de modernização retardatária (KURZ, 1992) levou a uma especificidade, na qual é possível reconhecer o colapso de maneira mais contundente. Este autor se refere ao conceito de modernização retardatária para lembrar a forma "atrasada" do Estado capitalista no Terceiro Mundo, enfrentando a crise decorrente do amadurecimento do capitalismo desenvolvido nos chamados países ricos para se firmar como a periferia econômica do mercado mundial. 
A crise do modelo fordista-keynesiano de produção e consumo esgotou-se nos anos 1970. Para conter essa crise, Crioni e Dias (2010) relembram que iniciouse um processo de reorganização do trabalho e enxugamento da rede de proteção social, que perdura atualmente de forma crescente. Entretanto, este modelo responde a uma grande contradição pelo fato de transparecer um rastro destrutivo proveniente da elevação das desigualdades socioeconômicas, da desintegração do aparelho de previdência social, da precarização do trabalho e desemprego estrutural. Consequentemente, é este único modelo disponível para as nações periféricas tidas como subdesenvolvidas frente a essa catástrofe econômica, política e social.

Nesse caminho que Kurz (1992) chama de colapso da modernização, está presente o indivíduo moderno. Este é fruto da subjetivação das categorias fetichistas trabalho, valor e mercadoria, já analisadas por Marx (1985), responsáveis por dar vida cotidiana à sociedade capitalista. Esse indivíduo moderno internaliza essa relação fetichista. Assim, o individualismo tornou-se até mesmo uma exigência do Estado e a partir daí, "o ser converteu-se em dever, e a modernidade européia tentou evoluir calcada na liberdade de opinião e de consciência, na tolerância e na justiça" (DUPAS, 2006, p.106). O indivíduo e, mais ainda, como sujeito sujeitado reflete a associação capital e trabalho.

O processo de modernização, no sentido de corresponder também a uma mudança de paradigma no âmbito científico, econômico, político e cultural, supera o pensamento clássico e leva a suposta concepção sobre civilização para além do eurocentrismo. Como nos lembra Guimarães (2002) o atual processo de modernização "foi fruto da obsolescência da idéia de civilização e tradição européias, trazida pelos horrores das guerras, principalmente das que, em 1914 e 1939, ganharam um caráter global” (2002, p.02).

A modernização está diretamente ligada ao movimento filosófico de esclarecimento, criticado por Adorno e Horkheimer (1985). Este por sua vez expressa-se como a maior concretização da liberdade do sujeito, vista como inseparável do pensamento "esclarecedor". Quando lançamos as considerações sobre a liberdade do trabalhador, face à mobilidade de sua força de trabalho, é que encaramos a perspectiva dos autores como crucial, no sentido de considerar que a liberdade representa o ideal mítico burguês de realização social. A livre mobilidade 
da força de trabalho (GAUDEMAR, 1977) parece ser uma condição necessária para a acumulação do capital.

Para estes autores, o esclarecimento corresponde ao ideal da sociedade burguesa, em todos os aspectos que incluem pessoas e instituições, dando destaque à forma como os fatos são moldados para evitar o "desvio social", seja na arte, na ciência, na política, no ensino, na literatura ou na filosofia. A intenção iluminista consistia na superação do mito da Idade Média, do obscurantismo religioso para a efetivação do saber e da razão. Estes passam a ser a fonte maior do poder. A crítica dos autores recai sobre o fato de o poder não conhecer barreiras e servir para todos os fins da economia burguesa.

O que Adorno e Horkheimer (1985) apresentam como idéia crucial acerca do poder exercido pelo conhecimento é que este possuía uma espécie de missão para desencantar o mundo e destitui-lo do animismo. Certamente, as ideias lançadas pelos pensadores burgueses e sua racionalidade acreditavam piamente na "verdade civilizatória européia" em que todas as áreas do conhecimento ocidental devessem ao grande avanço estabelecido pelas vias do progresso e da técnica (NASCIMENTO, 2008).

A contradição do mito da modernidade consiste na premissa de que ao mesmo tempo em que a concepção modernizante induz o sentido de uma superação da ignorância, do domínio das técnicas para o controle da natureza apregoa poder de decisão e ação para uma parcela da sociedade, enquanto para a restante, destituída dos aparatos e do conhecimento de seus mecanismos, é levada a contentar-se com o boom de informações e acesso a bens pelo consumismo. Mesmo se referindo de forma mais aprofundada à industria cultural e os aspectos difundidos por ela, os autores contribuem em demasia à reflexão sobre o pensamento burguês que forjou uma concepção sobre o sujeito esclarecido.

A sociedade moderna procura reduzir a heterogeneidade dos fenômenos a comparações lógicas, alegando que o que não se pode mensurar e reduzir a números, sinônimo de exatidão, está no campo da ilusão. Adorno e Horkheimer (1985) ainda afirmam que o intuito de destruir mitos pelo viés do esclarecimento na realidade os reconstroem sob novas roupagens, o que nos leva a pensar na sua contradição.

A contribuição maior da obra desses autores, para pensarmos a modernização, consiste em reunir a reflexão sobre as origens do pensamento 
ocidental e sua desastrosa incapacidade de resistir à moderna barbárie. Para pensarmos no continente africano ou no povo negro, a modernização como um caminho histórico é imprescindível se relembrarmos que foi somente neste período que supera-se a noção de civilização do modelo europeu para se pensar na construção do "outro".

Produz-se, de acordo com Quijano (2005), na perspectiva eurocêntrica do conhecimento, um dualismo entre moderno e pré-moderno, não-europeu e europeu, primitivo e civilizado ao mesmo tempo em que a linearidade da concepção evolucionista modula o que se entende por uma sociedade moderna. A partir das estruturas coloniais do poder que produz os binarismos maniqueístas do que se entende por civilidade, naturalizam-se as diferenças culturais entre os grupos humanos, diferenciando e classificando um sistema racial. A noção de raça é, portanto, uma invenção potente de hierarquização naturalizante das desigualdades sociais, "uma perspectiva crítica ao eurocentrismo e ao caráter colonial dos saberes que tem sido hegemônicos no sistema mundo moderno, nas chamadas ciências modernas, inclusive ciências sociais (QUIJANO, 2005, p.202).

É possível identificar nas correntes hegemônicas um substrato colonial que se expressa na leitura destas sociedades a partir da cosmovisão europeia e seu propósito de transforma-las à imagem e semelhança das sociedades do Norte, que em sucessivos momentos históricos serviram de modelo a ser imitado.

No entanto, produziram-se igualmente outras correntes de pensamento e outras opções de conhecimento sobre a realidade do continente africano, a partir das margens, na defesa de formas pré-modernas, alternativas, de conhecimento e expressão da resistência cultural, ou associadas às lutas políticas e/ou processos de mobilização popular.

Considera-se que as formas hegemônicas do conhecimento sobre estas sociedades operaram como eficazes artefatos de legitimação e naturalização da hierarquização e exclusão social que prevaleceu historicamente nestas sociedades.

Os saberes modernos hegemônicos contribuiram com a naturalização e legitimação do continuado processo de colonização e neo-colonização tanto externa como interna dos países de modernização retardatária do hemisfério Sul. Segundo Enrique Dussel (2005) o mito eurocêntrico desmorona-se a partir do próprio conceito de modernidade/a civilização moderna concebida como mais desenvolvida e superior; a superioridade obriga a desenvolver os mais primitivos, rudes, como 
exigência moral; o caminho deste processo educativo deve ser seguido a partir da Europa, não excluindo o uso da violência.

\section{Sobre o processo de modernização e a valorização do valor como ponto de partida}

Segundo Kurz (2005) na modernização, a estrutura social subordina o ser humano à valorização do capital. A essência do capital seria produzir, mediante a aplicação de força de trabalho humana, "riqueza abstrata" (MARX, 1985), num processo infinito de valorização como um fim em si mesmo. Nesse sentido Kurz (2005) e Scholz (2004) denominam a valorização do valor como uma característica fundamental do processo de modernização.

O valor, já comentado anteriormente, corresponde, na crítica fundamental do valor, a mais que um objeto da sociedade humana, é uma expressão fetichista tomada positivamente como objeto da sociedade humana. Ele é uma expressão de uma relação social fetichista. Conforme Scholz (2011), o entendimento sobre o valor recai sobre a forma mercadoria, ou seja, é preciso entender a produção de mercadoria como elemento da relação fetichista entre capital e trabalho em que ela se transforma em valor através da troca. Assim,

(...) as mercadorias são "valor" porque "representam" "trabalho abstrato" (dispêndio de energia social humana abstrata), ou seja, elas representam uma determinada quantidade de energia social despendida. Esta representação exprime-se por sua vez num meio particular, o dinheiro, que é a forma geral do valor para todo o universo das mercadorias. (SCHOLZ, 2011, p.01).

O preço de uma mercadoria corresponde então, a apenas um elemento do valor de uma mercadoria, sendo que a relação entre as pessoas e os produtos passam a ser mediadas pelo valor de uma mercadoria e não, de maneira simplória, apenas a seu preço. As pessoas são consideradas produtores privados isentos de relações, a não ser com os objetos, baseados na quantidade abstrata de trabalho dispendido para sua produção/confecção.

Para Höner (2004), o valor é o denominador comum das mercadorias, da energia humana gasta em forma de trabalho. Ele pode ser representado sob a forma mercadoria ou sob a forma dinheiro. Nesse sentido, 
(...) o valor veste, por assim dizer, primeiro a roupa de uma mercadoria, em seguida a do dinheiro, para transformar-se outra vez numa mercadoria (...) $O$ valor tornou-se o seu objetivo em si, sua instância que lhe dá sentido, ele inventa para si um vir a ser, um fim em si. A satisfação das necessidades humanas é reduzida a um simples meio, um mal necessário (...) Os homens tornam-se portadores de funções, de máscaras de um automatismo que os domina. Este automatismo não é outra coisa senão sua própria forma de mediação social, louca e inconsciente (HÖNER, 2004, p.01).

O valor não é visto somente como o sinônimo de dinheiro, mas como uma relação que afeta a sociedade levando a um processo de personificação dos produtos materiais ou objetos e do dinheiro em que as coisas são postas somente na quantidade de valor abstrato que representam. Tais autores asseguram que a mercadoria desligada das outras esferas da vida é um marco do capitalismo moderno. Nesse sentido,

(...) a produção de mercadorias, as relações monetárias e a "economia de mercado", como conexão sistêmica geral, só nasceram porque o valor, e com ele a sua forma de aparência, do dinheiro, se transformaram, de um simples meio que mediava produtores realmente independentes (economia familiar etc), num fim em si social universal: o dinheiro foi reacoplado a si mesmo como capital, para se 'valorizar', ou seja, para fazer do dinheiro 'mais dinheiro'(mais-valia) num processo imparável (SCHOLZ, 2011, p.30).

A valorização do valor torna-se o elemento chave da produção capitalista e a maneira como o trabalho abstrato se configura como automovimentação do dinheiro e como uma criação do capitalismo, portanto, moderno.

O indivíduo moderno, que se considera isoladamente, absorve-se na dimensão particular, recusa-se a se submeter às regras ancestrais exteriores à sua vontade íntima, que reconhece como lei fundamental apenas a sua sobrevivência e seu interesse próprio. Junto a essa formação do individuo surge o Estado centralizado e o indivíduo como cidadão. Assim,

(...) a impulsividade extrema e desenfreada dos homens, correlativa das sociedades que precedem o estado absolutista, foi substituída por uma regulamentação de comportamentos, pelo autocontrole do indivíduo, enfim, pelo processo de 
civilização que acompanha a pacificação do território realizada pelo Estado moderno (LIPOVETSKY, 1989, p. 161).

A sociedade produtora de mercadorias como modo de produção que corresponde à modernização, não é, para Crioni e Dias (2010), o resultado natural do desenvolvimento da humanidade. No contexto da modernização, o capitalismo é conseqüência de um desenvolvimento histórico não linear guiado por leis autônomas da produção de valor abstrato. (CRIONI e DIAS, 2010).

Robert Kurz (2002) é enfático ao dizer que o pensamento se estagnou nessa atual sociedade produtora de mercadorias. As ideologias da modernização criam novos termos para velhos conceitos, por exemplo, os conceitos do que é direita e esquerda, velho e novo, progresso e atraso nada mais são do que o "macaqueamento" de palavras que só reforçam os valores burgueses e ocidentais. Todas as ações estão fortemente ligadas ao ideal iluminista de individualidade.

O indivíduo moderno encontra-se no estágio de autodomesticação e, para a quebra desse estágio, Kurz (2002) reforça que é necessário que haja um processo de emancipação das relações de fetiche e dominação. Esta emancipação nasce de uma crítica radical em todas as esferas do cotidiano, sob suas formas culturais e simbólicas, a critica negativa que não se contenta em problematizar a sociedade moderna, mas rompe duramente com os mecanismos que a sustentam.

Essa teoria negativa existe como uma teoria critica do valor referente ao sistema produtor de mercadorias, mas não propõe estratégias concretas para a emancipação dessa base iluminista. Enfrenta, a seu ver, uma reflexão que ainda não problematiza o sujeito burguês e a ideologia iluminista como impositores do moderno sistema produtor de mercadorias, ela se ocupa em "derrubar a legitimação intelectual desta autodomesticação moderna do homem".

Todo este arcabouço teórico-metodológico lançado por nós é a base de nosso intuito em compreender a migração estudantil africana para o Brasil como um fenômeno particular de mobilidade da força de trabalho gerada pelo processo de modernização do capital enquanto relação social. A migração é um fenômeno moderno e se apresenta nessa conjuntura da imposição da autodomesticação humana, e da mobilização forçada do trabalho e para o trabalho.

A migração estudantil refere-se a uma particularidade desta mobilização forçada na medida em que maquia o colapso vivido pelo moderno sistema produtor de mercadorias a partir das concepções de integração, desenvolvimento e progresso 
no campo científico e tecnológico nos países atingidos pela modernização retardatária, dependentes do desenvolvimento capitalista global.

A acumulação primitiva culminou, a partir do entendimento de Marx (1985) expresso no capitulo XXIII de O Capital, na expropriação de terras e desenraizamento da população agrária européia do século XVIII, porém quando nos referimos à formação histórica das colônias, este processo não acontece de maneira semelhante, sendo o próprio Marx (1985) que alerta para o fato de que a expropriação da base fundiária assume versões diferenciadas nos diferentes países e percorre fases diversas em diferentes épocas históricas. Nesse sentido consideramos a particularidade histórica que envolve os países africanos, caribenhos e latinoamericanos na conjuntura atual.

Trata-se de mencionar a particularidade da formação sociall ${ }^{1}$ nestes países, correspondente à produção escravista moderna colonial distinta do escravismo antigo. Enquanto a expansão do Capitalismo gerou a acumulação de riquezas e o chamado trabalho livre nos países centrais, na periferia do sistema, que denominamos como países colonizados, produzia-se miséria e trabalho escravo (ALVES, 2006). É preciso refletir sobre a modernização retardatária nas colônias para que entendamos o processo de mobilização ocorrido na contemporaneidade e, particularmente, a migração em busca da qualificação da força de trabalho.

Posteriormente, destacamos o processo de modernização retardatária partindo da formação social escravista moderna nas colônias, com base em Marx (1985), Saes (1985), Gorender (1980). Esse tipo anômalo da modernização culmina com a especificidade social, política, econômica e cultural no Brasil e nos países africanos destacados para nossa investigação, sendo integrantes dos chamados PALOP (Países de Língua Oficial Portuguesa) Angola, Cabo Verde, Moçambique, São Tomé e Príncipe, Guiné Bissau e Timor-Leste. Diferentemente do escravismo antigo, o escravismo moderno incorporou como escravos membros de civilizações com organizações sociopolíticas e culturais distintas, o que evidenciou a violência racial nas formações sociais escravistas coloniais (SAES, 1985).

As bases do escravismo colonial moderno fincam-se no próprio escravismo antigo, no entanto, traz das negociações entre árabes e europeus uma de suas

\footnotetext{
1 Este conceito, com base em Saes (1985), necessita de uma definição de modo de produção numa "determinada realidade histórica concreta, singular, apreendida no tempo real e irreversível de um período determinado" (1985, p.59)
} 
especificidades como modo de produção moderno. Como nos apresenta Moore (2007) o sistema escravista desenvolvido pelos árabes-muçulmanos elegeu o continente africano como fornecedor da mercadoria "escravo" submetida ao trabalho nas mais diferentes nuances, servindo também de moeda internacional. Em decorrência da demanda árabe, muitas sociedades africanas se desestruturaram e tiveram suas bases sociopolíticas destruídas pelo mercado escravocrata externo.

Quando nos remetemos à problemática racial que envolve nossa particularidade em destacar pontos nesta tese, buscamos compreender a raça como importante aspecto que dialoga com os fenômenos migratórios ocorridos no processo de modernização.

Consideramos a raça como uma construção sociopolítica que supera as concepções biologizantes acerca das diferenciações fenotípicas e genotípicas relacionadas à capacidade intelectual e moral de grupos humanos. Embora o uso de tal termo tenha servido ao discurso ideológico da sociedade dominante e seus princípios iluministas para perpetuar a exploração e dominação de outros povos, descobertas cientificas posteriores condenaram o racialismo e sua repercussão social acerca da inferioridade e primitivismo de povos não-brancos e não-europeus e superioridade e genialidade branca-européia.

Importante destacar que no campo da estética e da filosofia, o racismo se constituiu como um elemento fortemente presente. Gilroy (2001) aponta que nas estéticas de Hegel, Schopenhauer e Nietzsche há referencias sobre o relativismo cultural e a intenção de considerar um juízo estético universal em detrimento de outros legados culturais. Assim, o debate sobre raças relacionado ao juízo estético e valor cultural foi banido da história do Ocidente e, o que pretendemos reforçar, embebidos na fonte da discussão cultural moderna de Gilroy (2001), é justamente a importância das discussões sobre raça, etnia e cultura na constituição do pensamento crítico ligado aos estudos ditos culturais. Para ele

(...) o uso do conceito de fetichismo no marxismo e nos estudos psicanalíticos é um meio óbvio para introduzir este problema. $\mathrm{O}$ caráter enfaticamente nacional atribuído ao conceito de modos de produção (cultural e outros) é outra questão fundamental que demonstra a especificidade etno-histórica das abordagens dominantes sobre politica cultural, movimentos sociais e consciências opositoras (GILROY, 2001, p.46). 
A concepção biológica no uso do termo raça buscou justificar a inferioridade de determinados grupos, em destaque, os negros. De acordo com Guimarães (1999), a hierarquia social sempre foi justificada por meio da ordem natural, a relação social é naturalizada. No século XIX, por exemplo, na Inglaterra a ordem econômica era justificada pela existência de virtudes individuais que os nobres possuíam e das quais os plebeus eram isentos; a subordinação da mulher era justificada por sua constituição biológica e a escravização de negros e negras era explicada pela inferioridade intelectual e moral. E sem exceção, todas as hierarquias sociais foram fundamentadas pela ciência a ponto de legitimar o discurso da superioridade de um grupo hegemônico representado por homens brancos ocidentais.

Segundo Guimarães (2002) o processo de modernização ou o que se refere, de algum modo, à modernidade enquanto um período histórico, forjou uma noção de Ocidente. O que tratava-se de civilidade correspondia, acima de tudo, ao distanciamento das camadas populares, dos gostos e costumes "bárbaros", do "outro". Internamente, a Europa deparava-se com as contradições entre camada popular e elite, externamente, apresentava-se as barreiras imensas em relação aos povos de outros continentes explorados.

Autores como Guimarães (2002) e Hernandez (2005) apresentam com ênfase o foco no processo de modernização para se pensar o continente africano e na própria questão racial por referir-se a toda construção estereotipada que incidiu, significativamente, na política local e nas intervenções chamadas de imperialistas.

Do ponto de vista dos estudos recentes sobre relações raciais, a modernização quebra com a concepção clássica ideológica de civilização, incorporando elementos de outros povos que, até então, encaixavam-se na concepção de bárbaros, selvagens e/ou semihumanos. Nos atemos à demarcação que Guimarães (2002) faz do início de uma problemática intelectual e acadêmica que envolve quem o Ocidente chamou de negros/as e, para nossa pesquisa, essa discussão é cabível no sentido de que procuramos situar a problemática racial no contexto da migração contemporânea, visto que trata-se de um fenômeno moderno, bem como a própria invenção da concepção de individualidade e identidade (SCHOLZ, 2011).

A modernização corresponde a um processo histórico do contato entre brancos e negros. A ligação dos povos africanos com europeus se deu muito antes 
da implantação do sistema escravista colonial e, face a isso, a representação dos/as negros/as foi construída no imaginário branco. O processo "modernizador" em si é decorrente de trocas, contratos e conflitos. Guimarães (2002) nos assenta quatro grandes épocas que marcaram tal processo, sendo

(...) (1) durante a escravidão de africanos e seu tráfico para as Américas; (2) durante o processo de integração dos negros às novas nacionalidades americanas, que se segue à abolição da escravidão: (3) durante a colonização da África pelos europeus e a subseqüente formação de uma elite africana, seja nas metrópoles ocidentais, seja nessas colônias; (4) finalmente, a quarta época se inicia com o processo de descolonização da Africa e a construção de novas nacionalidades africanas (GUIMARÃES, 2002, p.02).

É a partir dessa periodização que torna-se imprescindível fundirmos, numa perspectiva da crítica do valor, aspectos que integram a violência do sistema colonial, nas vertentes econômica, política, social e cultural. No processo de acumulação, segue o princípio da territorialização colonial e imposição do trabalho pela força (TOLEDO, 2008), o que faz sentido ao remetermos ao processo da modernização retardatária nos países colonizados, mais especificamente, as conseqüências do racismo moderno.

O chamado racismo moderno é intrínseco ao processo de acumulação primitiva nas colônias onde a escravidão correspondeu à base natural da riqueza colonial (MARX, 2001). Embora falemos da condição do trabalhador livre, numa liberdade negativa, como um elemento que constitui a chamada acumulação primitiva e "retira ao trabalhador a propriedade de seus meios de trabalho, um processo que transforma em capital os meios sociais de subsistência e os de produção e converte em assalariados os produtores diretos" (MARX, 2001, p.828), relembramos a diferenciação da forma "trabalhador escravo", do escravo enquanto propriedade. Uma consequência desse processo é a herança histórica da representação social estereotipada sobre o/a negro/a na diáspora.

O escravismo colonial, como uma formação social, incorporou populações consideradas tecnicamente inferiores (SAES, 1985), consolidando, assim, a violência, a desumanização e o racismo como elementos centrais. Portanto, a maneira como o moderno sistema produtor de mercadorias forjou a acumulação 
primitiva nas chamadas colônias corrobora com a naturalização histórica do racismo no "Terceiro Mundo".

Moore (2010) enfatiza as causas do chamado subdesenvolvimento do continente africano em relação aos demais continentes a partir de um estudo histórico minucioso em fontes de pesquisadores africanos e africanistas no sentido de demonstrar que a colonização foi apenas um aspecto assolador para os povos e etnias africanos, bem como as idéias vigentes acerca do racialismo propagado pela elite dominante e pensante do continente europeu que acometeu as sociedades africanas. Numa tentativa de explicar o "extermínio" de povos africanos a partir da colonização européia, ele afirma que

(...) existem aqueles ingênuos- ou aqueles que fingem sê-loque se perguntam o motivo pelo qual o continente africano se encontra hoje na situação tão desastrosa em que está, especialmente se comparado à situação do resto do planeta. Ainda existem aqueles que, negando as evidencias que apontam para os tráficos negreiros e para a colonização da África como sendo rotundos crimes contra a humanidade, negam, inclusive, o caráter fundamentalmente racista dessas investidas da Europa contra os povos negros desse continente. A hemorragia humana que a África conheceu com os diferentes tráficos negreiros, de uma parte, e com a colonização européia, de outra, nunca teve paralelos na historia da humanidade. Simplesmente, se tratou de um genocídio racial (MOORE, 2010, p.68 e 69).

É evidente que a assertiva do autor ao se referenciar as causas do que chamamos de modernização retardatária no continente africano, se edifica no genocídio racial como ponto de partida. No entanto, é preciso ressaltar também que o próprio fundamento da acumulação primitiva de Capital é de grande importância na leitura atual sobre a realidade do continente, como já foi evidenciado no capítulo anterior.

Partimos de uma leitura em que a dissociação do valor apresenta-se como um importante fator na análise crítica sobre a modernização retardatária no continente africano. Portanto, relatar e basear-se no genocídio racial ou racismo moderno como elemento crucial na concepção e representação sobre o que é o continente africano ou o que é ser africano/a induz-nos a ampliar o valor-dissociação para as esferas do político, econômico e cultural na leitura sobre aspectos dos 
países africanos lusófonos que, para nosso foco de investigação, remetem ao ensino superior, à qualificação e, consequentemente, à migração estudantil.

Os estudos raciais ou aqueles que valorizam a racialização - polarização entre negros e brancos - podem ser repensados enquanto única perspectiva de compreensão de fatos sociais, principalmente, se estamos tratando de um grupo social fortemente marcado pela raça, etnia e, no caso de imigrantes, pela nacionalidade. $O$ ponto chave destes estudos ainda é fortemente a cultura ou a identidade cultural, o que pode levar a uma visão limitada ou restrita a respeito dos elementos sociais que abrangem a questão racial $e$, consequentemente, a discriminação racial. De acordo com Costa (2006)

(...) os estudos raciais transformam a existência objetiva do racismo num fato absoluto que dispensa a decodificação social, fazendo com que aqueles que não constroem suas identidades com base na polarização entre brancos e negros sejam tratados como portadores de uma consciência racial pouco desenvolvida (COSTA, 2006, p.216).

Desse modo, a dinâmica da integração cultural, torna-se uma "mera variável subordinada da integração social" (2006, p.217). A integração cultural é, sim, uma importante forma de decodificação social que interage e constitui a dinâmica social em sua totalidade, não sendo, portanto, mais ou menos importante que a integração social.

Se pautarmos nas considerações sobre cultura, do ponto de vista da geografia, podemos nos remeter à maneira como ela se interrelaciona com os conceitos de espaço e identidade. Não há uma relação equânime entre espaço, lugar e cultura se quisermos compreender a relação do migrante com o espaço. As análises pós-coloniais problematizam a relação entre espaço e cultura no sentido de pautar na necessidade de se repensar os conceitos de diferença cultural, comunidade e identidade no âmbito de uma esfera transnacional na sociedade atual.

Segundo Gupta e Ferguson (2000) esse repensar o espaço demonstra que as comunidades atuais, ou grupos sociais dos quais incluímos jovens estudantes africanos no Brasil, se reconstruíram sobre as bases de uma esfera transnacional imbuída de novas formas de pensar/viver a cultura, seja com base na produção industrial de cultura, diversão e lazer, seja na criação de novas formas de 
solidariedade em estados-nações longínquos na realidade migratória que apresentam, consequentemente, novas experiências de espaço.

Por estas bases, adentremos nossa discussão sobre o continente africano, sobretudo os países de língua portuguesa, sendo Angola, Cabo Verde, Moçambique, Guiné-Bissau, São Tomé e Príncipe como sujeitos sujeitados à violência da acumulação primitiva do Capital e as conseqüências da modernização retardatária às sociedades atuais na corrida pela qualificação.

A qualificação da força de trabalho é uma consequência do processo de modernização e o ensino superior transforma-se, para este fim, em mercadoria importante numa sociedade em que pesa a produtividade, o desenvolvimento e o progresso. Os/as estudantes africanos/as são sujeitos nesse processo e nos leva a compreender a condição migrante do ponto de vista do acordo entre Estadosnações, da expectativa de sucesso profissional, da percepção racial e construção de um grupo social que enfrenta conflitos sociais, raciais e culturais. 


\section{CAPITULO I}

\section{A MOBILIDADE DO TRABALHO, A MIGRAÇÃO E A QUESTÃO RACIAL NO CONTEXTO DA CRÍTICA DO VALOR-DISSOCIAÇÃO}

\subsection{0 fenômeno migratório: uma compreensão crítica a partir da mobilidade do trabalho}

Ao pensarmos na questão migratória numa forma geral, partimos da compreensão dos avanços lançados pela perspectiva crítica para considerar as determinações e transformações ocorridas com a consolidação do moderno sistema produtor de mercadorias, seu funcionamento e processo de exploração.

No sentido mais simples, as bases de investigação pautadas no materialismo histórico procuram não considerar a migração como escolha individual ou soma de escolhas individuais, mas sim como um processo social em que participam grupos sociais rumo ao mercado de trabalho propriamente capitalista (PÓVOA NETO, 1997). Para nossa análise, os estudantes africanos constituem-se como grupo social sujeito às transformações socioeconômicas de seus países. A possibilidade de migrar, antes de tudo, apresenta-se como um processo social em que o grupo social envolvido é uma corrente que emana de estruturas societárias geograficamente delimitadas (SALIM, 1992).

A concepção neoclássica implica em considerar o econômico na análise das migrações, através da "vontade" do mercado de trabalho e do indivíduo em buscar melhores condições de vida através de uma melhor remuneração.

Vários autores/as das ciências sociais e da Geografia buscaram compreender a questão migratória a partir da leitura analítica de Gaudemar (1977), obedecendo às transformações ocorridas em cada momento histórico e lançando um olhar sobre as implicações que os deslocamentos de pessoas trazem à organização políticoeconômica dos espaços de forma a revisitar e/ou transcender o pensamento gaudemariano com as novas leituras sobre as migrações, as políticas e estratégias adotadas para o controle. Buscamos dar visibilidade às reflexões desses/as autores/as sobre o fenômeno migratório na modernização, todavia, Gaudemar (1977) considera a mobilidade num contexto mais amplo, não se limitando aos processos migratórios (TOLEDO, 2008; VAINER, 2005; PÓVOA-NETO, 1997). 
Gaudemar (1977) apresenta uma abordagem fundante na discussão sobre a mobilidade do trabalho quando analisa-a do ponto de vista crítico-marxista, contrastando-a com a chamada axiomatização neoclássica da mobilidade perfeita do trabalho. Assim, o autor supera o conceito intuitivo de mobilidade do trabalho ligado à sua dimensão meramente espacial ou setorial. A mobilidade passa a ser estudada, no âmago dos processos de reprodução do capital, como a característica da força de trabalho que permite seu uso no modo de produção capitalista.

O trabalho é uma das categorias mais importantes na constituição do pensamento crítico sobre o modo de produção capitalista. Mesmo em um momento em que alguns/mas estudiosos/as têm deslocado a preocupação ontológica com o trabalho a partir da crítica ao processo de modernização, ainda há uma vasta gama de autores/as que discutem, a partir de Marx, a consolidação do trabalho como meio de produção e reprodução da mais-valia e da força de trabalho como a mola propulsora do fortalecimento do Capital. Cabe a nós considerarmos também, embora não seja a grande questão aqui, os avanços na crítica ao fenômeno migratório na Geografia, do ponto de vista do trabalho.

Ressalta-se aqui as considerações de Marx (1985) sobre o trabalho, visto como um elo de ligação entre o ser humano e a natureza em que o primeiro "media, regula e controla seu metabolismo com a natureza" (1985, p.30). Nesse processo de auto-realização da humanidade através do trabalho, há de se reconhecer o conteúdo do metabolismo social do capital que faz com que a relação sociedade e natureza seja considerada pela Geografia como base fundamental na compreensão dos vários significados do trabalho no mundo atual ou, usando as palavras de Antunes (2002), da "classe-que-vive-do-trabalho".

Para essa perspectiva que considera o trabalho como ontológico, o ser humano é capaz de efetuar a transformação material ao mesmo tempo em que sabe que determina a espécie e o modo de sua atividade. O processo de trabalho é a atividade que tem a finalidade de produzir valores de uso que saciam a necessidade humana. $O$ impasse surge quando esta atividade responde ao processo de consumo da força de trabalho pelo capitalista em que o/a trabalhador/a exerce sua atividade controlado/a pelo capitalista, o dono de sua força de trabalho. Além disso, o produto produzido pelo/a trabalhador/a é, puramente, propriedade do capitalista, visto que ele paga pela força de trabalho dispendida, ele a utiliza como qualquer outra mercadoria. A partir do momento em que o capitalista compra a força de trabalho 
do/a trabalhador/a, ele incorpora o trabalho como um elemento constitutivo do produto (MARX, 1985).

É a partir do trabalho que lança-se a formulação e compreensão do significado de mobilidade do trabalho, cunhado por Gaudemar (1977) na perspectiva crítico-marxista, embora apresente um aprofundamento teórico em relação ao que Marx pouco se debruçou. O autor salienta a razão pela qual apresenta novas bases para se pensar a mobilidade do trabalho, visto que a economia política clássica invisibilizou o processo histórico no debate sobre o trabalho e seus desdobramentos.

Gaudemar (1977) procura não se ater às variáveis do trabalho como exploração, mais-valia e força de trabalho, ao passo que enfatiza a natureza da força de trabalho que se presta de maneira intensiva e extensiva e como designar a sua qualidade. Por meio dessa investigação sobre a qualidade da força de trabalho é que o autor se lança na investigação sobre o conceito de mobilidade do trabalho. A reflexão sobre esse conceito induz ao questionamento sobre o uso do trabalho e dos corpos pelo Capital.

Com esse ponto de partida, o autor vai desmontar o discurso econômico neoclássico e suas estratégias para explicar a mobilidade. É importante destacar, desde já, que mobilidade não é apenas deslocamento espacial, mas inclui a reflexão sobre qualquer alteração da utilização da força de trabalho no processo produtivo. Cabe, portanto, estudar a noção de mobilidade e a investigação das causas dos movimentos que ela indica.

É a partir desse pano de fundo que Gaudemar (1977) construirá seu conceito marxista de mobilidade do trabalho, valendo-se de um contraste com o que chamou de "axiomatização neoclássica da mobilidade perfeita do trabalho". Para isso, o autor contesta a abordagem neoclássica sobre a mobilidade do trabalho.

Por outro lado, é evidente a passagem efetuada por Marx da esfera da circulação, enfatizada pelos neoclássicos, para a esfera da produção, nos termos inicialmente colocados acerca da ruptura epistemológica que o mesmo promove na economia. Em suma, o objetivo é demonstrar como as diferentes utilizações de uma mesma idéia, qual seja a da mobilidade perfeita do trabalho, podem ter funções absolutamente diferentes segundo a matriz teórica a que estão ligadas.

Na primeira tese enunciada pelo autor a mobilidade passa a ser estudada, no âmago dos processos de reprodução do capital, como a característica da força de trabalho que permite seu uso no modo de produção capitalista. Sua segunda tese é 
a de que o silêncio dos economistas a respeito da mobilidade do trabalho é um equívoco de percepção, não se tratando de uma possível marginalidade do conceito.

A mobilidade, portanto, consiste na indiferença da força de trabalho em relação às condições de seu exercício, qualquer que seja a dimensão considerada, ou seja, é uma manifestação da abstração do trabalho. A mobilidade do trabalho é a condição da gênese e do desenvolvimento do capitalismo, em suas múltiplas dimensões de produção das forças de trabalho, utilização no processo de produção e circulação entre os territórios e as esferas de atividade. A mobilidade do trabalho, portanto, intervém na extração da mais-valia absoluta (aumento da duração da jornada ou do número de jornadas) e relativa (aumento da intensidade ou da produtividade do trabalho).

A denominação "mobilidade do trabalho" de Gaudemar (1977) explica-se na medida em que há um uso capitalista dos corpos dos trabalhadores. Esse uso permite um deslocamento espacial e refere-se tanto a localizações bem como ao uso dos corpos em diferentes condições de intensidade e ritmos de produção, sempre com o propósito de extrair a máxima produção de valor.

Se a mobilidade torna-se um instrumento de adaptação da mão-de-obra, os deslocamentos espaciais não são os únicos em causa, como também o são os modos de passagem da mão-de-obra disponível para as esferas de valorização do capital e todos os modos de intensificação e produtivização desta mão-de-obra. Estas formas implicam no encorajamento dos movimentos migratórios, polarizando espaços para o desenvolvimento capitalista. Gaudemar (1977) argumenta que a força de trabalho mobilizada tende a dispor os lugares para o desenvolvimento do capital, o que implica uma mobilidade sem preferências, porque ao trabalhador importam os melhores ganhos em salários.

A conclusão de Gaudemar (1977) é criticar a mobilidade forçada do trabalho atendendo às determinações da reprodução do capital. Assim, por um lado, eliminase do esforço conceitual acerca da mobilidade do trabalho o individualismo metodológico, uma vez que o trabalhador deixa de ser visto como agente que decide apenas maximizar seu salário, mas é levado à mobilidade pelo sistema produtor de mercadorias.

Nesse ínterim, a preocupação diante dessa reflexão consiste em debruçar-se sobre os/as trabalhadores/as migrados/as, em condições cada vez mais precárias de trabalho e deslocamento. Os/as imigrados/as, assim, constituem uma força de 
trabalho móvel que pode ser deslocada de estabelecimento para estabelecimento ou de ramo para ramo, segundo a conjuntura e que pode ser devolvida à procedência sem tensões nem gastos sociais importantes. Seus deslocamentos são submetidos à exigência da lei e das necessidades do capital - mobilidade forçada, não disponibilidade dos mesmos direitos sindicais, não-direito à expressão cultural própria. A consideração sobre a mão-de-obra migrante é de suma importância no entendimento da crise no mundo do trabalho e dos mecanismos utilizados para a superação da crise do Capital.

No entanto, há a perspectiva sobre a crítica ao trabalho, defendida por autores da teoria crítica social como Kurz (2005) que evidencia o colapso vivido atualmente em que "cada vez mais pessoas se tornam "supérfluas", porque não podem mais vender a sua força de trabalho". O trabalho, nessa ótica, está em crise, ou de certa forma, não é mais a categoria central para se entender ou tecer a crítica a este sistema moderno produtor de mercadorias. Assim, ele diz que

(...) as pessoas não estão coercitivamente "liberadas" das relações agrárias para o trabalho abstrato, mas estão sendo catapultadas para fora do próprio trabalho abstrato. O pano de fundo não é mais, no entanto, a mobilização da força de trabalho para o capitalismo, mas a desmobilização mundial da força de trabalho na terceira revolução industrial, que estragou o apetite do capital por "hands" (mão-de-obra) (KURZ, 2005, p. 03).

O que Kurz (2005) e os críticos radicais do trabalho querem evidenciar é que o trabalho não é apenas o dispêndio concreto de dispêndio de energia humana, visto que no sistema produtor de mercadoria ele é uma abstração real representada pela forma dinheiro. Como a finalidade desse sistema é fazer mais dinheiro, tal abstração também se concatena ao processo de trabalho material. A crítica ao marxismo tradicional refere-se ao fato de ter considerado o trabalho como aspecto positivo, na sua concepção ontológica e violentado exteriormente pelo capital, no entanto, a permanência da concepção positiva acerca do trabalho abstrato, para este marxismo, continua ilesa.

Nesse sentido, buscaremos levar a discussão referente à migração estudantil a partir da critica radical ao trabalho e ao valor, sabendo da necessidade de considerar o trabalho nessa sociedade moderna da economia de mercado, incluindo o ponto de vista da qualificação da força de trabalho para onde e para quê. O que 
configura é a impressão de que o processo de modernização, por mais que abarque diferenciações locais, regionais e mundiais, refere-se a uma conexão global, tudo está interligado, ele cobre o mundo inteiro. Assim também entendemos que, num primeiro momento, mesmo com as fundamentações teóricas que temos acompanhado, a migração de estudantes também faz parte desse ciclo do colapso que provoca a mobilização da força de trabalho.

Nossa preocupação com a migração estudantil como um fenômeno contemporâneo da crise do sistema moderno de mercadorias, apresenta um pressuposto: as transformações ocorridas no mundo do trabalho sustentadas pela crise da produção e do capital são o principal drama que envolve milhares de trabalhadores no deslocamento e o oferecimento de sua força de trabalho como condição para sua sobrevivência (ALVES, 2004). Para compreendermos melhor esta assertiva, vejamos as contribuições de alguns autores que alçaram a discussão sobre a mobilidade do trabalho a partir de uma perspectiva crítica. É essa discussão inicial que subsidia nossa preocupação com a mobilidade social em tempos de crise do sistema capitalista. Na realidade, a migração estudantil, foco central de nossa pesquisa, é apenas um aspecto do fenômeno migratório e também está sujeita às transformações do mundo do trabalho.

\subsection{As migrações e o contexto da lógica do trabalho}

A partir do conceito de mobilidade do trabalho, podemos aferir a questão migratória, primeiramente, nos referindo ao contexto da reestruturação produtiva. Nesse sentido, a análise de Gaudemar deve ser retificada com a consideração de que a condição móvel dos vendedores de força de trabalho obedece às necessidades do sistema moderno produtor de mercadorias. O Capitalismo precisou e precisa apelar para a produção da mobilidade, para a produção do trabalhador flexível.

Antunes (2002) faz uma discussão crítica do mundo do trabalho com a crise do capitalismo. Segundo ele, a crise provocou profundas mudanças no mundo do trabalho, como o desemprego estrutural e condições precárias de trabalhadores. 0 Capital cria mecanismos de superação da crise, reorganizando seu sistema de dominação. Acontece que a reestruturação produtiva em tempos de neoliberalismo, agravou a crise. 
Este autor considera a crise estrutural do modo de produção capitalista a partir do fordismo no decorrer das décadas de 1960 e 1970 em decorrência de queda nas taxas de lucro, diminuição do consumo com o desemprego estrutural, hipertrofia da esfera financeira etc. Além de outras catástrofes, em termos sociais, houve uma intensificação da exclusão de países do Terceiro Mundo do compromisso social-democrata.

O aumento gradual da reestruturação produtiva nos anos 1990, no contexto da crise e internacionalização da economia, alterou substancialmente o funcionamento do mercado de trabalho, aumentando as taxas de desemprego, precarização e informalização do trabalho (ARAÚJO e FERREIRA, 2000). Tais transformações nas cadeias produtivas culminaram com uma profunda contradição do processo de transformações produtivas com inovações tecnológicas cada vez mais avançadas e contratação de mão-de-obra pouco qualificada.

Frente à tal contraditoriedade, surge um paradoxo de estabilidade e de instabilidade da força de trabalho (HIRATA, 1984). A chamada estabilização corresponde a um mínimo de trabalhadores/as qualificados/as com relativa autonomia e responsabilidade na produção, enquanto a instabilização tem uma demanda global e favorece o aumento do desemprego e subemprego, além de uma superexploração do/a trabalhador/a.

Ao mesmo tempo em que o Estado procura exercer o poder, não consegue responder pelas mudanças decorrentes da crise como se não pudesse obter controle sobre elas. No que tange às delegações do Estado e de sua soberania, no raciocínio de Haesbaert e Porto-Gonçalves (2006), ele, pela constituição jurídica, deveria ter o controle exclusivo de relações sociais pelo controle do espaço, mas essa premissa foi abalada com a ampliação das escalas a nível global sobre poluição, gestão de recursos naturais e mobilidade da população através das redes de migração globalizadas.

Numa perspectiva geográfica, para Thomaz Junior (2002) é recorrente apontarmos que o processo de reestruturação produtiva do capital provoca um extenso conjunto de modificações no âmbito do trabalho e isso remete a profundas alterações no espaço e no território (enquanto categorias de uso interligado), portanto, em diferentes escalas de análise. Esses referenciais teóricos nos põem na linha de frente para captarmos o movimento através das suas contradições, pelo viés da sua dimensão espacial. A consolidação da reestruturação produtiva do 
capital traz a "pedagogia da competitividade" e das vantagens competitivas, num contexto marcado pela mundialização do capital e pela difusão das políticas neoliberais (THOMAZ JUNIOR, 2002). Para este autor,

A Geografia contribui com o desvendamento das manifestações territoriais do processo social, possibilitandonos o entendimento das transformações no mundo do trabalho a partir dos rearranjos espaciais que dão formas e contornos e se fundamentam sobre conteúdos sociais diversos, ou seja, enquanto processo histórico de construção e transformação, que por sua vez, substantiva-se em ordenamento territorial diferencial (THOMAZ JUNIOR, 2002, p.17)

Nessa perspectiva de salientar as contribuições da geografia na compreensão e análise do trabalho e de suas contradições Thomaz Junior (2002) assegura que nós, geógrafas/os, nos sentiríamos impossibilitados para entender as características espaciais do mundo do trabalho se não houver uma preocupação em abordar as contradições do processo social que marcam as trocas e determinações da dimensão do trabalho em todas as escalas. A complexidade das relações econômicas, políticas e culturais na dinâmica da sociedade também interferem no mundo do trabalho.

Advém os mecanismos de uma espécie de novo contrato de trabalho, fortemente flexibilizado, com a forte tendência a generalização e imposição da mobilidade da massa trabalhadora para atender as exigências conjunturais e estruturais do capital (SILVA, I., 2008). A dinâmica da mobilidade obedece aos lugares em que se almeja o desenvolvimento do capital, o que Gaudemar (1977) já afirmava a inexistência de preferências por localidades do ponto de vista do/a migrante, pois o alvo corresponde aos melhores ganhos em salários, representando a indiferença do sujeito moderno regido pela submissão ao movimento do capital.

Como afirma Kurz (2005), a mobilização da força de trabalho para servir a expansão capitalista formou, em todo o processo de modernização, o pano de fundo de todos os movimentos migratórios particulares e distintos. Diferente da discussão que a economia política travou, do ponto de vista crítico-marxista, sobre a mobilização da força de trabalho para o capitalismo, na sociedade atual vemos a mobilização mundial da força de trabalho que coloca em xeque a chamada capacidade de desenvolvimento capitalista. Ainda segundo este autor, 
(...) É preciso deixar de dar explicações do tipo 'o ser humano sempre fez guerras e sempre migrou'. Isto não ajuda a compreender este fenômeno que é inédito e nunca ocorreu em tão alta escala como agora. A migração não é nada novo na história da modernização, mas, sim, há um erro na avaliação ao dizer que as pessoas migram livremente em busca de melhores condições. É um processo coativo. Os pobres são livres para vender sua mão de obra, porém fazem isto porque não têm condições para controlar sua existência. A transformação da sociedade capitalista numa situação mundial produziu uma sociedade de exclusão. O ser social participa de um sistema no qual vende abstratamente sua força de trabalho e integra uma engrenagem (montada) para produzir acumulação infinita de capital (...). (KURZ, 2005, p.31).

O autor enfatiza a maneira como o caráter da liberdade incide sobre o/a trabalhador/a à medida em que ele se sujeita a migrar para oferecer sua força de trabalho e ser protagonista de uma situação marginal em outro espaço, alimentando a produção e reprodução desenfreada do capital. Porém, o/a trabalhador/a não vê que é peça essencial da engrenagem perversa do modo de produção vigente.

$\mathrm{Na}$ linha de raciocínio da critica radical à contemporaneidade e as transformações decorrentes dos caminhos estratégicos de fetichização da mercadoria em todos os âmbitos da vida social, verificamos que, em relação ao mercado mundial, a imposição do alto nível de produtividade dos países capitalistas centrais obriga os países denominados periféricos a acompanhá-los por meio do desgaste da sua força de trabalho.

Nossa sociedade se alimenta da produção de mercadorias e o trabalho humano é a mola propulsora para esta produção. Os deslocamentos de trabalhadores são os subterfúgios adotados nesse momento em que já não é possível absorver mão-de-obra num determinado espaço, ocorrendo o fluxo à medida que o capital se mostra ávido por resistir aos seus próprios fracassos. Dessa forma, na situação atual do mundo, o que vemos é o volume alarmante de migrações em escala mundial nunca visto anteriormente, embora o tráfico negreiro, nos séculos XVII, XVIII e XIX, tenha sido responsável pelo deslocamento forçado de africanos/as para as Américas.

A preocupação em compreender os deslocamentos de trabalhadores/as para a produção e reprodução do capital, suscita-nos a considerar a migração mundial como um fenômeno de um desenvolvimento social concreto (KURZ, 2005) que não 
a considera como uma transformação cultural, de hábito essencialmente humano. Há um dinamismo na lógica globalizante e sua força principal reside na concepção e ação de integração econômica, forjada, imposta e gerenciada pelo liberalismo (MARTINE, 2005). Os países centrais são beneficiários deste gerenciamento, o que provoca o aumento da disparidade social e econômica e os bolsões de pobreza espalhados pelo mundo todo. São estes fatores os principais norteadores para alguns tipos de migração na sociedade atual.

Para entender fenômenos como a guerra de novo tipo e as migrações maciças de novo tipo é necessário analisá-las na sua dependência do desenvolvimento do capitalismo global, de seus fluxos de dinheiro e mercadorias, como também da sua capacidade maior ou menor de aplicação de força de trabalho. Só a partir desse pano de fundo, ambos os fenômenos podem ser entendidos no seu nexo interno.

A migração atual tem a sua característica, não é mais limitada a determinadas levas não-simultâneas da modernização em diversos países, mas é universal e global. A causa: a nova migração maciça desde o final do século XX é conseqüência de uma nova crise socioeconômica. Na realidade, o que carrega uma concepção de homogeneização (HAESBAERT e LIMONAD, 2007) é a influencia e dominação do capital (dinheiro) e a pobreza e a miséria àqueles que foram entregues a um processo de modernização retardatária.

Por essas assertivas, é que vemos a necessidade de considerar o/a próprio/a migrante como agente e produto dos deslocamentos. As migrações sempre deixam marcas visíveis na paisagem, assim como a urbanização e industrialização e a fluidez e a dinâmica do espaço confirmam a importância delas. Há estudos que atentam para o caráter de "deslocado" do/a migrante, de uma espécie de desespacialização vivida por ele/a, a sua desterritorialização, transforma-o num objeto de exploração capitalista ainda mais frágil e submetido (POVOA NETO, 2001).

A migração é um importante elemento na reprodução das relações da força de trabalho e no processo de expansão do mercado de trabalho. As transformações sociais e políticas na sociedade moderna estabelecem, cada dia mais, uma preocupação com as novas formas de inserção no mundo do trabalho e na manutenção da exploração do/a trabalhador/a. 
Percebemos que, nos intercursos disciplinares, nas trocas possíveis entre ciências, diferentes são os enfoques dados no que diz respeito à migração contemporânea. Seja no destaque às transformações econômicas como responsáveis pelos deslocamentos, seja na constituição da sociedade moderna, o/a migrante é o sujeito sujeitado ao mundo do trabalho, na venda de sua força de trabalho por um "preço" módico.

É de nosso interesse alçarmos reflexões sobre a atual conjuntura em que se insere o/a migrante na condição de temporário, de futura mão-de-obra qualificada, como é o caso do estudante migrante. Sabemos que ele/a também é figura ímpar atingida pelas crises sucessivas do capital e que constitui um dos principais pontos de investimento e promessa de "desenvolvimento" do país de origem. A literatura referente ao/à migrante na ciência geográfica apresenta uma reflexão do ponto de vista do trabalho, da (re)inserção no mercado e trajetórias, impressões e (re)territorialização que compreende um processo complexo de construção de territórios múltiplos (HAESBAERT,2009).

A produção da mobilidade continua existindo, com novos papéis e novas formas. A contribuição de Gaudemar (1977) para nossa reflexão vem no sentido de afirmar que a condição móvel dos vendedores da força de trabalho não é inerente, não é inata, mas adquirida e produzida historicamente e o capitalismo precisa apelar para a produção da mobilidade, para a produção do trabalhador flexível que tem de se dobrar às necessidades do Capital.

Dentro de um determinado espaço territorial (PÓVOA NETO, 2001), o migrante, que rompe barreiras legais, terá muito mais que se sujeitar à exploração econômica e, com isso, firmar-se como uma das figuras mais frágeis e submetidas no processo de construção de novas relações de produção e da venda de sua força de trabalho. Esse ponto de partida nos traz possibilidades de pensar a condição do/a migrante estudantil e temporário sob o ponto de vista também das expectativas criadas durante o processo de formação.

O/a migrante é o/a estrangeiro/a, independente de ultrapassar limites territoriais nacionais, regionais ou locais, pois adentra um espaço que não é o seu, é ali, essencialmente, força de trabalho, uma força de trabalho provisória, temporária e em transito (SAYAD, 1998). Mas esse estrangeiro, não raras vezes, permanece no limite territorial do "outro", rompendo com o caráter provisório de sua condição, torna-se um sujeito que permanece, mesmo em condições provisórias, 
estabelecendo relações de proximidade e afastamento, indiferença e envolvimento. Como diz Sayad (1998), ele/a passa a viver a dura condição do eterno no provisório à medida que pensa a sua condição como temporária, mas se constitui numa rede de relações sociais e de trabalho que o/a induz ao sentido da eternidade, da permanência.

Nesse sentido, é importante destacarmos que a realidade da migração e os fatores que a envolvem são de ordem política, econômica e cultural. A presença do estrangeiro acaba levando a mesclas e a fusões e à construção de novas identidades. Isso vai de encontro ao mito de que as diferenças nacionais tendem a se extinguir, pois, quando aparecem os/as imigrantes, fica nítido que as identidades de cada grupo estão mais vivas do que nunca e continuam correspondendo a sistemas hierárquicos.

\subsection{Migrações, mobilidade do trabalho e mobilidade estudantil}

As migrações correspondem a um fenômeno de destaque nas novas relações no mundo do trabalho. Para uma análise da mobilidade de população é necessário haver uma compreensão do mundo do trabalho e, na contemporaneidade, da situação de crise do setor produtivo (ALVES, 2004). De acordo com este autor,

(...) uma sociedade produtora de mercadorias, como a nossa, que ainda se sustenta no trabalho humano, se ressente quando ela já não consegue dar conta de absorver parte da mão-de-obra disponível. Dessa maneira, cada vez mais um volume de trabalhadores se coloca em movimento, deslocando-se para onde ainda vislumbra possibilidades de alcançar um posto de trabalho, mesmo que isso seja apenas um ato visionário (ALVES, 2004, p. 45).

Por isso, a migração não pode ser definida, de maneira simplória, como mobilidade espacial da população, porém, como um conceito complexo que repercute em mudanças nas relações de produção e reprodução do espaço. As principais correntes teóricas que se debruçaram sobre a questão migratória foram a clássica e a marxista, sendo que, até a década de 1970, predominava a perspectiva clássica, enquanto o marxismo apresentou uma abordagem crítica no entendimento das migrações. A Geografia, até este período, adotou uma análise das migrações do 
ponto de vista clássico e, posteriormente, ela passa a ser investigada sob diferentes pontos de vista teóricos.

A perspectiva clássica baseava-se na análise descritiva e dualista, dando ênfase aos índices de fluxos demográficos e vontades individuais do migrante, negando o processo histórico na formação social. De acordo com Becker (1997) essa abordagem correspondia a um modelo reducionista da realidade ao considerar a sociedade do ponto de vista da individualidade, levando a constatação de que a migração é a busca pessoal por melhoria de vida e uma contribuição para o equilíbrio das relações de mercado.

O que a abordagem marxista procura apontar é justamente a idéia de que a mobilidade populacional não trata de uma vontade pessoal, mas das necessidades do capital de se reproduzir. Gaudemar (1977) apresenta-se como um dos primeiros teóricos a mencionar o termo "mobilidade forçada" que corresponde, justamente, a essa não vontade pessoal, pois o individuo se vê forçado a migrar pelos arranjos socioeconômicos estabelecidos no mundo do trabalho.

O neoliberalismo econômico cria uma nova gestão do trabalho, com o intuito de controlar a qualidade da produção ao mesmo tempo em que aumenta a exclusão do/a trabalhador/a. Nesse sentido, Becker (1997) afirma que a estruturação da sociedade capitalista como uma sociedade do trabalho está em crise. Para ela

(...) um novo paradigma das migrações está em gestação como resultante da atual internacionalização da economia; desenvolve-se numa conjuntura onde de um lado ocorre a reestruturação tecnológica e, de outro, o aprofundamento da exclusão social (BECKER, 1997, p. 331).

A mobilidade constitui-se, então, como uma estratégia para perpetuar as desigualdades de espaço, pois ele não atende as necessidades da população. Atualmente o "exército de reserva", utilizado em um momento histórico anterior ao atual, são menos fundamentais na discussão sobre mobilidade populacional, pois esse "exército" são os/as trabalhadores/as repelidos pelos setores da economia moderna e cada vez mais supérfluos na economia moderna. Eles/as perdem seus empregos e não sempre são deslocados para outras atividades e subempregos.

Atualmente as camadas populares e a própria classe media tem buscado a migração como solução para as diferenças entre o numero de assalariados e desempregados. A negação sutil e, ao mesmo tempo, gritante do direito ao trabalho, 
alimentação, moradia e demais serviços básicos para a população obriga a mesma a migrar continuamente na tentativa de driblar o desemprego e a impossibilidade de competir, mas tais assertivas só escondem o verdadeiro sentido da perversidade das velhas medidas reformuladas do sistema econômico para se manter e, assim, a população se engana com a idéia de ascensão e melhoria maquiados pelo aumento do número de empobrecidos e concentração de riquezas.

Temos que nos atentar, como já discute Martins (1998), sobre a falácia da idéia de exclusão perpetuada pelo capital quando discutimos a situação dos/as migrantes. Para este autor, o conceito de exclusão é um dos fundantes na análise e compreensão do fenômeno migratório na contemporaneidade, visto que a sociedade moderna produtora de mercadorias, na realidade, não exclui, ou, de certa forma, lança a exclusão para incluir e, para pertencer a essa sociedade, transforma todos em produtores e vendedores de mercadorias. Assim, todos/as devem batalhar para serem incluídos na sociedade do trabalho, devem oferecer a força de trabalho e, consequentemente, tentarem continuar como consumidores/as, pois é necessária a manutenção de um ciclo vicioso.

Podemos pensar a migração estudantil acadêmica por esse fio condutor. Do ponto de vista da busca pela qualificação profissional, imbuídos de um discurso que representa interesses governamentais e familiares, ávidos de representarem uma elite pensante ou modernizante no país de origem. Não é possível negar ou desconsiderar que o grupo social em questão faz parte da engrenagem que mantem seus estados presos aos mandos e desmandos de um sistema. Como salienta Desidério (2006)

Os novos movimentos migratórios de estudantes estrangeiros inserem-se em um processo mais amplo, caracterizado pela globalização, pela internacionalização da educação superior, bem como pela institucionalização dos sistemas educativos que incorporam os Acordos de Cooperação como perspectiva de desenvolvimento humano, social e econômico (DESIDÉRIO, 2006, p.24).

O estímulo à migração internacional, provocado pelas concepções neoliberais "globalizantes", não é acompanhado por um aumento correspondente de oportunidades, pois os países que atraem migrantes bloqueiam sua entrada. $O$ 
chamado "Mundo Sem Fronteiras" é parte da definição da globalização, mas não se aplica ao movimento de pessoas (MARTINE, 2005). Este autor acrescenta que

(...) o capital humano é um fator de produção que, formalmente, não tem livre trânsito entre fronteiras nos dias de hoje; não existe um "mercado global de trabalho". As fronteiras abrem-se para o fluxo de capitais e mercadorias, mas estão cada vez mais fechadas aos migrantes: essa é a grande inconsistência que define o atual momento histórico no que se refere às migrações internacionais (MARTINE, 2005, p.8).

No contexto do desenvolvimento capitalista, a mobilidade da força de trabalho desempenha um papel importante. A idéia de que o livre comércio alavanca a produção mundial com o rompimento de fronteiras e o fluxo livre de pessoas não procede quando analisamos as condições a que os/as migrados/as são e estão submetidos/as.

Também para Harvey (2009) a força de trabalho é a única mercadoria que pode chegar ao mercado por seus próprios pés. Na modernidade, o/a trabalhador/a é responsável por si mesmo/a, no sentido de decidir seu próprio destino e, com essa máxima, coloca-se em evidencia a liberdade como principio e condição da mobilidade do/a trabalhador/a. A liberdade fundamenta a perspectiva clássica no entendimento da mobilidade, no seu caráter duplo, positivo e negativo (GAUDEMAR, 1977).

Do ponto de vista histórico-estrutural as escolhas individuais não explicam os fluxos populacionais, mas sim o espaço da estrutura capitalista que movimenta, expande ou retrai. Para Vainer (2005) impõe-se a relação que submete todos os movimentos espaciais à lógica da dinâmica do capital, isto é, "a absoluta mobilidade e a total falta de raízes são a sinalização de que ele [o/a trabalhador/a] é totalmente despossuído dos meios de produção e subsistência, portanto, subordinado ao capital e a seu movimento" (VAINER, 2005, p. 263).

Os apontamentos teóricos de Gaudemar (1977) apreendem que os/as trabalhadores/as deslocam-se pelo mundo tratando de escapar das depredações do capital, evitando a exploração, sempre lutando, às vezes com algum êxito, para melhorar sua vida. Na busca de emprego e de salário, o/a trabalhador/a segue ao capital onde ele estiver, de preferência, onde é mais valorizado. Essa relativa "elasticidade" e "docilidade", melhor dizendo, mobilidade geográfica da força de trabalho, assim como a "indiferença" dos trabalhadores ao conteúdo do seu trabalho 
são essenciais para a "fluidez do capital". Ela corresponde até mesmo à condição necessária para a acumulação do capital. Essa chamada "indiferença" do/a trabalhador/a corresponde a esse estado de adormecimento em que se encontra diante de sua situação como explorado, como um sujeito sujeitado as mazelas da sociedade produtora de mercadorias.

Caminhamos para uma compreensão critica da mobilidade do trabalho a partir do momento em que negamos a existência ontológica de um suposto homo migrans. Deslocamentos de populações foram constantes na historia da humanidade, porém, apenas a sociedade moderna se caracteriza pela mobilização geral e forçada para as funções do trabalho (HEIDEMANN, 2004).

O mundo atual se depara com a perversidade sistêmica constituinte de um desenvolvimento negativo das relações sociais em que se acirra a competitividade para fazer valer atitudes hegemônicas de manutenção e centralização do poder, o que Santos, M., (2000) afirmava ser característica fundante do processo de globalização. O período permanente da crise atual atua na medida em que as variáveis que constituem o sistema se chocam e exigem outras definições e alterações e, quando elas se consolidam, a crise se reinstala. Portanto, se trata de um fenômeno estrutural em que as soluções que não visam uma mudança basilar geram mais crise.

Para nomear a sucessão de crises do sistema atual, Santos, M., (2000) utiliza-se da idéia de tirania que abarca o próprio capital - o dinheiro - e a informação, correspondendo ambos aos "pilares da produção histórica atual do capitalismo globalizado" (Santos, M., 2000, p.35).

Compreendemos que as análises econômicas, pertinentes ao fenômeno migratório, focalizam as relações entre migração e desenvolvimento econômico. Dessa maneira, aspectos como a divisão internacional do trabalho, os mercados internacionais, os desequilíbrios regionais e a precarização do trabalho na estrutura global (BÓGUS; BASSANESI, 1998), são fatores que representam o limiar da crítica sobre as migrações.

No sentido de considerar a liberdade do/a trabalhador/a e a chamada dimensão positiva de sua liberdade focamos o/a estudante migrante que se vê na condição livre para buscar alternativas de estudo e, posteriormente, de trabalho, ou seja, ele/a representa um trabalhador/a em potencial, embora há fatores decisivos para sua entrada no mercado de trabalho, como as relações familiares, as 
necessidades das empresas e do próprio Estado, a escolha pela continuidade dos estudos na pós-graduação etc.

A mobilidade do trabalhador é comandada pela necessidade do capital. Có (2004) salienta que, no caso de Guiné Bissau - que se estende, em certa medida, aos outros países lusoafricanos, a migração para Portugal, um dos principais países de destino da população lusoafricana, teve um crescimento fragmentado por fases, primeiramente obedecendo ao modelo de centralização do Estado guineense que não permitiu a emergência do setor privado, posteriormente, o advento das políticas de liberalização econômica na década de 1980 e, por fim, a degradação das condições socioeconômicas, a instabilidade política/institucional e o conflito políticomilitar entre 1998 e 1999. Todos estes fatores motivaram intensos fluxos migratórios ao longo dos tempos.

Alguns autores buscam considerar a (re)construção de trajetórias "individuais" de migrantes estudantes africanos (SUBUHANA,2005; HIRSH, 2007; DESIDÉRIO, 2006; MUNGOI, 2006). Nossa discussão atua dentro do contexto do sistema produtor de mercadorias em que o migrante é um sujeito histórico, protagonista social e cultural dessa organização econômica e social e é assim que entenderemos o mundo contemporâneo e o novo migrante nessa configuração (HEIDEMANN, 1998)

Gusmão (2009) demonstra uma abordagem política do cenário de migração temporária para fins de estudo entre África e Brasil, posto como um desafio de reflexão e compreensão se partirmos da ideia de desenvolvimento via campo educacional. É inconteste que a educação insere-se no universo das relações de poder estabelecidas nacional e internacionalmente, pautando-se como um meio instrumental de "manutenção e reprodução do status quo ou um instrumento de libertação e autonomia para os países em consolidação enquanto Estados nacionais" (GUSMÃO, 2009, p.285).

$\mathrm{Na}$ visão da autora há uma espécie de libertação ou independência de um Estado-nação quando investe na educação e aumenta o quadro profissional, no entanto, o que não podemos esquecer é o discurso presente nessa assertiva que vista a competitividade no mercado em crise em que a educação passa a ser mais um objeto de mercadoria a ser barganhada nessa corrida da/na crise. Tudo atrela-se à história contemporânea dos Estados-nação africanos na luta para consolidarem-se como nações modernas e transnacionais. Os acordos bilaterais que referenciam a 
educação como elemento chave fazem parte desse jogo entre as nações envolvidas e demonstra o papel dos PALOP (Países Africanos de Língua Oficial Portuguesa) nas relações Sul-Sul. A autora ainda afirma que

(...) a Circulação Internacional com finalidade de estudo se faz no interior de um campo de poder que envolve a possibilidade da ascensão social e política para estudantes, famílias e grupos sociais diversos que ordenam por mecanismos singulares um campo de tensão entre sujeitos migrantes quando fora de seu lugar (GUSMÃO, 2009, p.286).

O que se verifica, desse modo, é a dissonância entre o dinamismo econômico que impulsiona e alimenta novas modalidades migratórias sem uma preocupação com a condição do migrante ou, o que na literatura, denomina-se efetivação dos direitos humanos. Sabemos o quão é escorregadio o discurso positivo dos direitos humanos como um decreto para algo que deveria ser ontológico. Nossa intenção não é opor-se às contribuições de autores/as sobre a importância da politização/discussão sobre os/dos direitos humanos ou os avanços perpetrados pelos órgãos mundiais, nacionais e locais acerca da luta pelos direitos de humanidade. Boaventura Santos apud Tannuri (2010) afirma que a crise dos projetos de emancipação das forças progressistas buscavam a linguagem da revolução e do socialismo e, desde então, os direitos humanos têm sido invocados como que para preencher espaços vazios. (TANNURI, 2010). O trabalho de Tannuri (2010) expressa uma militância a favor do reconhecimento dos grupos refugiados no Brasil e uma maior preocupação política com esta problemática. A importância da integração local, via redes sociais perpassa por um entendimento da necessidade de encarar as políticas que visam os direitos humanos como fundamentais para um processo de (re)construção da cidadania destes grupos, o que podemos considerar relevante e nos ajuda a pensar as migrações do ponto de vista da solidariedade, da convivência e da (re)construção de identidades.

Kurz (2005) ressalta que as novas modalidades migratórias, e aqui incluímos a estudantil, não estão agregadas a compromissos internacionais que visam o reparo ou a atuação dos direitos humanos, pois evidenciar a superficialidade das intenções promovidas pelas instituições estatais e econômicas é invisibilizar os conflitos de interesses de grupos hegemônicos na competição para o mercado e a dinâmica que atinge os estudantes que se destinam a vagas em universidades 
brasileiras. É recorrente em suas falas a ideia de cursarem determinados cursos para auxiliarem no desenvolvimento e qualidade de vida de suas famílias e de seus países, mas o que acontece é uma decisão compulsória dos programas que os inserem num ranking de demandas por regiões e universidades, o que, na maioria das vezes, acaba por determinar o deslocamento para alguma cidade e universidade diferente da pretendida.

\subsection{Migração e a questão racial: o racismo no processo de modernização em bases da teoria do valor-dissociação}

Há muito nos focamos na importância da discussão racial para basearmos nosso entendimento sobre a migração estudantil africana, em especifico a migração para a qualificação, no entanto, nossa intenção é, antes de tudo, apontar, a partir da critica do valor-dissociação, a possibilidade de tratar a questão de uma maneira que abranja vários processos envolvidos e não somente a partir de uma perspectiva fenomênica da cultura.

Para isso, nosso principal aporte teórico para pensarmos nossa problemática empírica, principalmente quando envolve a discussão racial, vem de Scholz (2004). Esta autora relembra que a "culturalização do social" (SCHOLZ, 2004, p.01) começou a ser considerada palavra-chave para o entendimento dos problemas sociais e econômicos. Tal perspectiva foi/é bastante utilizada pelas convenções chamadas pós-modernas e/ou pós-coloniais que acabam, segundo a autora, caindo numa ontologização das diferenças, sem compreender criticamente o que chamamos de sujeito sujeitado, representado aqui pelos grupos sociais que correspondem ao valor-dissociação, alvos das manifestações de racismo, sexismo, dentre outros tipos de discriminação.

O/a migrante estudante é um/a sujeito sujeitado na sociedade moderna, representa os anseios individuais e coletivos pela transformação esperada pela qualificação. Sabemos que, antes de tudo, a qualificação no ensino superior representa as estratégias desenvolvimentistas dos países envolvidos, nas quais o estudante automaticamente se envolve, visto que sua vinda e permanência dependem consideravelmente dos trâmites legais oferecidos pelos programas de convênio entre os países africanos e o Brasil. No entanto, ao assumir seu status de 
sujeito sujeitado em país estranho, é perceptível o peso da disparidade social que o envolve, abarcando aqui sua condição racial sua classe econômica.

Isto que nos leva a refletir sobre o valor-dissociação como um caminho teórico para refletir/criticar a sociedade para além das teorias marxistas e pós-coloniais, pois ao considerar o gênero, a raça e a etnia também como condições fundantes da desigualdade social, fugimos do reducionismo teórico e das individualizações e estendemos a critica a estes aspectos há décadas marginalizados pelos teóricos sociais e até mesmo pela teoria critica.

A teoria do valor-dissociação resgata a estrutura das desigualdades sociais nos aspectos políticos, econômicos, sociais e culturais e serve para "tematizar a relação assimétrica entre os sexos, mas, [...] igualmente serve para tematizar o racismo, o antisemitismo e as disparidades materiais; e de tal modo que estes não se vêem reduzidos a meras contradições colaterais" (SCHOLZ, 2004, p.01), contestando, assim, a própria critica superficial pautada somente na divisão de classes sobre o capitalismo e suas conseqüências.

Nesse sentido, visamos tratar a diferença de uma maneira que abarque as dimensões social-estrutural, a individual e o plano do valor-dissociação em que

(...) a dimensão social-estrutural [...] diz respeito a diferenças entre disparidades económicas, racismo, antisemitismo e sexismo; [...] no plano individual, sendo que ninguém se resume a estruturas, constitui[ndo] antes um indivíduo inconfundível e singular, sem, no entanto, poder subtrair-se às estruturas; finalmente no plano fundamental do valordissociação, como princípio da forma social, que, no entanto, contrariamente a uma lógica dedutiva universalista clássica, [...] admite por si o particular e as diferenças, como quero demonstrar (SCHOLZ, 2004, p.01).

Em outros aspectos, esta abordagem nos acrescenta para a tese, consideravelmente, pelo fato de romper com a estrutura universalizante da critica radical que se fundamentava, assim como a tradicional ciência, numa perspectiva patriarcal e branca. Romper com esta perspectiva é repensar o próprio método de investigação/preocupação em que as variáveis raça, gênero e classe correspondem a um complexo indissociável, um processo histórico-dinâmico. Ao contrário do que se acredita, “(...) não se trata de pensar a cultura per se. A política da cultura em sua síntese esta inteiramente conectada com a política econômica, a ecológica e com a política de resistência." (SMITH citado por SUERTEGARAY, 2009, p. 109). 
A crítica da dissociação e do valor inclui também a crítica às diferenças, pois, para Scholz (2009)

tematizar também outros momentos do não-idêntico, e assim formas de discriminação como o racismo, o anti-semitismo e o anticiganismo do mesmo modo que o sexismo, e também ainda admitir o Outro tecido "de outra maneira" que mesmo aí não fica absorvido" (SCHOLZ, 2009, p. 18).

A discussão sobre as diferenças questiona as formas iluministas eurocêntricas de compreender/explicar a realidade que negligencia a teia de relações imbricadas entre povos com organizações sociais, econômicas, politicas e culturais distintas e que, a partir das experiências com a diáspora, problematizam a construção do ser negro e as representações acerca das diferenças.

Autores pós-coloniais como Costa (2006), Gilroy (2001), Hall (2011), Bhabha (1998) problematizam a modernização como um processo de influência ocidental europeia no mundo, demonstrando que o diálogo, os conflitos com outras civilizações e a diáspora forçada trouxeram, por parte dos pensadores desta geração, outros olhares e análises reflexivas sobre o ser negro e as diferenças.

No entanto, para Costa (2006), as teorias pós-coloniais não são homogêneas, mas todas elas representam uma tentativa de referenciar uma epistemologia crítica à concepção moderna dominante de ciência e fazer ciência. Foi a partir dos anos 1980 que inicia-se o boom do pensamento pós-colonial, liderado por intelectuais do chamado Terceiro Mundo na Europa e expandindo-se para outros continentes e disciplinas. Dentre esta perspectiva, baseamo-nos em Bhabha (1998, p.239) que afirma que tais teorias "emergem do testemunho colonial dos países do Terceiro Mundo e dos discursos das 'minorias', intervindo nos discursos ideológicos modernos que buscam normatizar as realidades de diferentes nações, raças e povos". Ele reforça a importância de se encarar a cultura, nesse caso, acima de tudo, como estratégia de sobrevivência, sendo, portanto, transnacional e tradutória. Assim

(...) ela é transnacional porque os discursos pós-coloniais contemporâneos estão enraizados e histórias específicas de deslocamento cultural, seja como "meia-passagem" da escravidão e servidão, como "viagem para fora" da missão civilizatória, a acomodação maciça da migração do Terceiro Mundo para o Ocidente após a Segunda Guerra Mundial, ou o trânsito de refugiados econômicos e políticos dentro e fora do Terceiro Mundo (BHABHA, 1998, p.241). 
Ao considerar a cultura como um elemento de (re)existência nosso olhar sobre os/as estudantes africanos/as permeia no âmbito da cultura enquanto um elemento da forma social que permite a construção e reconstrução de suas identidades durante a moradia/estadia no Brasil, na afirmação de laços de solidariedade e afinidades entre si, seja ao dividir a moradia, ao falar o crioulo em ambientes públicos, ao promover festas temáticas, muitas delas, não abertas a brasileiros/as.

Reiteramos que a possibilidade de considerar as fundamentações acerca da construção da identidade na sociedade moderna e o diálogo com a teoria do valordissociação, esta se pautando mais profundamente à crítica ao patriarcardo produtor de mercadorias, é um importante fio condutor para a crítica à migração estudantil africana negra. 


\section{CAPÍTULO II}

\section{OS ACORDOS DE COOPERAÇÃO E A EDUCAÇÃO: DIÁLOGOS POLÍTICOS ENTRE BRASIL E ÁFRICA A PARTIR DA MIGRAÇÃO ESTUDANTIL COMO ESTRATÉGIA}

\subsection{A África Lusófona no contexto da integração político-econômica ao mercado mundial: fragilidades do processo de modernização retardatária}

A aproximação entre Brasil e África em termos de fortalecimento das relações político-econômicas e culturais deve-se, primeiramente, ao denominador comum da colonização, a qual nos apresenta como base para uma discussão do fenômeno migratório estudantil africano/a e da crescente procura pela formação/qualificação como estratégia social nas últimas décadas. Assim, a migração de estudantes africanos/as perpassa por este contexto histórico de colonização e modernização retardatária de um continente explorado como base da acumulação primitiva e do Brasil com esta similaridade, embora as diferenciações estejam resguardadas e constituem um universo de geografias imaginativas, aproximações e distanciamentos.

A particularidade do processo de colonização portuguesa face aos países africanos traz uma necessidade de evidenciarmos a relação entre colônia e metrópole que configurou o processo histórico de formação e estruturação política e econômica dos países afrolusófonos.

Hernandez (2005) procura evidenciar características particulares do império marítimo português para o significado do continente africano na sua estratégia econômica, política e cultural. O imaginário, embora seja um aspecto simbólico, é crucial para se compreender a ligação/exploração do continente africano por vias portuguesas, no sentido de que Portugal construiu o mito do Eldorado que versava sobre a crença na riqueza das colônias africanas, na compensação das mesmas após a perda do Brasil e capaz de manter a integridade nacional portuguesa mesmo em outro continente.

A superioridade cristã atribuída a Portugal foi um importante fator na consolidação e manutenção do que se denomina como "Império" português. Chegou-se a afirmar, por meio de escritos documentais e até mesmo na literatura de Luís de Camões, Eça de Queiroz dentre outros, que Portugal era uma expressão da vontade de Deus; o seu povo "era o povo de Cristo, cujo papel era o de descobridor e colonizador nas terras da África, do Oriente e do Brasil" (HERNANDEZ, 2005, 
p.505). Havia o princípio de que os não-civilizados deveriam se transformar moral e socialmente para alcançarem uma civilização europeia. $O$ etnocentrismo português foi, sem dúvida, um grande aliado na constituição de colônias portuguesas no continente africano no sentido de perpetuar uma forjada superioridade em termos de organização política, de dominação territorial e cultural sobre os nativos e a propagação da língua portuguesa como elemento de poder.

A temática referente à colonização e seus impactos presente nos debates e estudos sobre o continente africano, contribui para o que Moore (2010) chama de "demonização" da África que afirma formas inferiores de organização e pensamento e a eterna propensão à escravidão.

Não há como esquecer que a história ocidental eurocêntrica cravou sobre o continente africano o imaginário social da desorganização, da desestruturação, do atraso moral, intelectual e político. Esse imaginário ganha força no cenário do racionalismo imperante no século XVIII saudado pelo pensamento moderno e/ ou a chamada modernidade. Nascimento (2008) e Moore $(2010,2007)$ discutem a maneira como as representações a respeito do continente africano construídas mediante a exploração e o genocídio são fortalecidas até os dias de hoje na consolidação da afirmação do atraso e da miséria como elementos intrínsecos ao continente africano. No entanto, de uma maneira incisiva, estes autores buscam a perspectiva para o entendimento da situação econômica e política do continente, inclusive, atribuindo ao processo histórico de trocas com o continente europeu e Oriente Médio como um dos grandes responsáveis pela fragmentação desconexa e a desigualdade existentes nos países africanos.

Autores que versam sobre a história do continente africano (HERNANDEZ, 2005; KI-ZERBO, 1999; MOORE, 2007; APPIAH, 1997) trazem a premissa de considerar as especificidades, a continuidade de um continente que não existiu apenas durante e após a "partilha" colonialista. O saber ocidental instituiu visões de mundo, estereótipos que marcam equívocos e geografias imaginativas sobre a África.

Embora nossa intenção seja considerar uma leitura do continente africano, em particular de seus países lusófonos, que abarque o processo de modernização no seu particular "retardamento", lembramos em Hernandez (2005) e Freyre (1961) a singularidade do processo colonizador português que nos dá bases para discutirmos 
do ponto de vista político, econômico e cultural os países de língua portuguesa no continente africano no contexto das migrações estudantis.

De antemão, muitas são as questões que lançamos acerca dos elementos que aproximam países africanos lusófonos do Brasil e, embora apresentemos uma tendência em explicá-los do ponto de vista de uma leitura que entende a migração de estudantes africanos/as como um elemento da lógica moderna produtora de mercadorias, o que tentaremos expor aqui são as ideologias forjadas por pensadores lusotropicalistas como estratégias de aceitação da colonização e manutenção de interesses políticos e econômicos e dependência das chamadas colônias.

Freyre (1961) elabora uma concepção de familiaridade entre o português e o trópico, causando uma espécie equilíbrio entre colônia e metrópole. Salientamos que o ponto de partida de sua tese adentra o universo simbólico, afirmando que Portugal teria uma cultura transeuropéia, sendo, assim, um país do mundo. Trata-se de evidenciar a mobilidade portuguesa como criadora de uma sociedade híbrida, miscível, responsável pela formação de povos irmãos e a articulação de etnias e culturas (FREYRE, 1961, p.13).

A corrida pela construção de uma nação híbrida percorreu as expectativas de pensadores brasileiros, portugueses e caboverdianos. Assim, um dos fundamentos desse ideal era afirmar que "a integração portuguesa nos trópicos [era] um dos maiores empreendimentos da [...] época, de se reorganizar o sistema de relações de brancos com povos de cor, dentro de um critério de interpenetração não só cultural como étnica de valores que, em vez de repudiar, valoriz[asse] a mestiçagem". (FREYRE, 1961, p.20).

Tal observação também foi discutida por Hirsch (2007) no sentido de alegar, a partir das construções ideológicas marcantes em Cabo Verde e no Brasil, a mestiçagem como síntese bem sucedida (HIRSCH, 2007), colocando brancos, negros e mestiços como responsáveis isonômicos da formação social. A "morenidade" serviu, nestes termos, para aproximar interesses políticos entre Cabo Verde, Brasil e Portugal.

A ênfase na "morenidade" ou no discurso mítico da democracia racial é uma premissa utilizada por caboverdianos e brasileiros, o que nos remete a aproveitar as reflexões de Martes (2003), quando apresenta a relação existente entre etnicidade e raça na medida em que a identidade nacional se junta à identidade racial retratando 
- Brasil e Cabo Verde como mistura de todas as raças, motivo de diferenciação nacional e superioridade àqueles países em que os conflitos raciais são visíveis.

Por aí vemos mais um motim estratégico de Portugal para que sobressaísse uma concepção ultramarina, única e reveladora da eficiência do modelo colonizador imposto. Na analise feita por Penha (2011), preocupado em discutir a formação da bacia econômica ${ }^{2}$ do Atlântico Sul e em particular a relação Brasil-África, os portugueses tiveram a pretensão de transformar o Atlântico em um domínio marítimo semelhante ao domínio terrestre comandado pelos romanos. Muitas indagações cercam o autor que, numa perspectiva da geopolítica, procura entender as estruturas de poder que definiram as políticas externas no âmbito sul-atlântico. É recorrente a assertiva de que Portugal desenvolveu uma mentalidade política voltada para o mar (ALENCASTRO, 2000). Ao investir em expedições marítimas, navios, caravelas de alto porte e capacidade de carregamento de mercadorias, os lusitanos asseguraram políticas de controle das rotas das Índias e o comércio atlântico de negros escravizados.

Enquanto os espanhóis buscavam ocupar e conquistar novos territórios, os portugueses objetivavam estabelecer uma rede de postos de comércio e militar a fim de comercializar mercadorias e levá-las para a metrópole. No século XVII, Portugal consolida seu controle marítimo no Atlântico Sul, fortalecendo os laços econômicos e estratégicos que viriam a, posteriormente, com a acumulação primitiva, desenvolver o comércio açucareiro e a mão-de-obra africana. Desse modo, a dependência das aristocracias africanas frente ao colonizador português correspondeu à "organização do poder metropolitano, à acumulação do capital comercial e à lógica da escravatura moderna” (PENHA, 2011, p. 35). A relação existente entre Portugal, África e Brasil intensificou-se à medida em que o primeiro visou formar uma zona de interação econômica, com parceiros em outros continentes e aumentar a utilização da mão-de-obra escrava.

Mesmo após o auge da escravidão e do domínio ultramarino português, não podemos deixar de considerar a intensidade das relações sociais e produtivas entre Brasil, África e Portugal. Ao pensarmos as migrações contemporâneas de africanos para o Brasil relembramos a proximidade entre os três países e ainda ficamos intrigados com o fato de ter havido um abismo entre o continente africano e os

\footnotetext{
2 O termo bacia econômica é utilizado pelo autor no sentido de atribuir três significados: 1 - natureza fisiográfica; 2- natureza econômica; 3- natureza geopolítica (PENHA, 2011)
} 
demais, mesmo após a intensidade das relações e estratégias comerciais travadas entre ele, em destaque as colônias portuguesas, e o Brasil.

Portugal representou a mediação entre África e Brasil ao longo dos séculos no processo de modernização e, desde então, o fluxo de mercadorias e pessoas, por meio do tráfico negreiro, subsidiou uma relação de interdependência e proximidade. Porém, após o período de descolonização do Brasil, houve um "afastamento" do continente africano, decorrente do desinteresse europeu e, segundo tese defendida por autores como Saraiva (1994) e Guimarães (1999), da necessidade em moldar uma nação pautada nos parâmetros europeus de civilização, política e estética.

Vários foram os estudiosos que defendiam afirmações de que o continente africano representava 0 atraso, o oposto da modernização que impedia 0 fortalecimento das relações comerciais e políticas com os demais Estados-nações. No Brasil, autores como Nina Rodrigues (1982) tornaram-se célebres em afirmar a inferioridade dos africanos e de sua incapacidade de "desenvolver" e "progredir". Ao defender uma nação puramente brasileira e enxergando uma "saída no fim do túnel" para o problema da miscigenação ${ }^{3}$, o autor apresenta sua visão racializada e racista sobre as sociedades africanas e confere uma importância ao estudo das influências de África no Brasil e na interpretação de dados estatísticos referentes ao deslocamento espacial de etnias a partir do tráfico negreiro. Diz ele que

(...)a raça negra no Brasil, por maiores que tenham sido os seus incontestáveis serviços à nossa civilização, por mais justificadas que sejam as simpatias de que a cercou 0 revoltante abuso da escravidão, por maiores que se revelem os generosos exageros dos seus turiferários, há de constituir sempre um dos fatores da nossa inferioridade como povo (RODRIGUES, 1982, p. 7).

É notória a referência neste autor de que os africanos são povos destituídos de organização política, econômica e cultural, no entanto, concorda com Silvio Romero (citado por RODRIGUES, 1982) que eles devem servir de objeto de estudos, até porque havia uma necessidade de transformar o Brasil numa nação mestiça futuramente branca. De maneira contundente, estes autores acreditavam que estudar os negros africanos seria um avanço para a ciência brasileira no

\footnotetext{
${ }^{3}$ Nina Rodrigues (1982, p.5) afirma que, com a miscigenação, "os negros existentes se diluirão na população branca e estará tudo terminado".
} 
objetivo de entender o pensamento primitivo destes povos que, de maneira otimista, declaravam que desapareciam em breve. Podemos verificar essa passagem quando Rodrigues (1982) transcreve Silvio Romero em sua alerta para a necessidade destes estudos.

(...)É uma vergonha para a ciência do Brasil que nada tenhamos consagrado de nossos trabalhos ao estudo das línguas e das religiões africanas. (...) O negro não é só uma maquina econômica; ele é antes de tudo, e malgrado sua ignorância, um objeto de ciência (RODRIGUES, 1982, p.16).

Tais autores propunham que o Brasil desse uma contribuição científica sobre os colonos africanos, que se destacasse no cenário da investigação cientifica naturalista que buscava, por meio de análises morfológicas, comprovar a inferioridade moral e cultural dos africanos.

Sem dúvida, a África Lusófona guarda o ranço da influencia portuguesa em diversos aspectos. A partir das conversas com os estudantes vemos que eles/as estão atentos/as à influência da herança portuguesa, principalmente na língua, mas em nenhum momento se afirmam com certo orgulho ou destaque a proximidade com Portugal como referência de civilidade.

\subsubsection{Brasil-África no contexto do mercado mundial}

Ao situarmos as relações políticas entre países africanos de língua portuguesa e o Brasil, reordenações ocorridas com a divisão internacional do trabalho travam o diálogo entre eles, em alguns momentos frágil, em outros intenso, de acordo com os interesses diversos no contexto das relações internacionais. É nesse cenário que as migrações especiais com finalidade de estudo (GUSMÃO, 2008) ganham destaque como um projeto de qualificação de quadros nacionais em países de modernização retardatária.

Por conseguinte, é importante destacar que países africanos de língua portuguesa estão inseridos num contexto que envolve o Brasil, país de escolha para a qualificação via educação, que tem apresentado um quadro de abertura política com relação à África e expandido o sistema educacional com o advento de mais programas de graduação e pós-graduação nas IES como um todo, mais instituições 
privadas de ensino que têm apresentado a necessidade de programas de intercâmbio a partir de acordos de cooperação internacional.

Os projetos de cooperação internacional que visam a migração estudantil referem-se, por conseguinte, a estratégias de desenvolvimento dos países envolvidos, portanto, podem ser possibilidades de realização de metas individuais e/ou familiares e também de âmbito nacional/governamental. Gusmão (2008) reflete que o processo de internacionalização do ensino no Brasil contribui para um entendimento do campo político da formação de nível superior - envolvendo negros/as estrangeiros/as africanos/as que estudam nas IES brasileiras - que traz à tona as relações historicamente constituídas entre África e Brasil, a realidade educacional de ambos e a construção contemporânea das chamadas "elites nacionais" nos países africanos em questão. (GUSMÃO, 2008).

O ano de 2002 representou um marco importante, do ponto de vista de uma homogeneização atrelada aos interesses de Portugal, entre o Brasil e a Comunidade dos Países de Língua Portuguesa (CPLP) que culminou com as novas sanções estabelecidas no sentido de destacar potencialidades e parcerias. Dentre as estratégias visadas, podemos citar a redução de barreiras internas das legislações nacionais, cooperação técnica na área da saúde e ciências em geral, além de transferência de tecnologias.

A CPLP, desde sua criação em 1996, ainda não teve tempo para se libertar das diferenças e particularidades provenientes da convivência histórica dos oito países integrantes (Angola, Brasil, Cabo Verde, Guiné Bissau, Moçambique, Portugal, São Tomé e Príncipe, Timor-leste). O surgimento da CPLP aconteceu numa época em que as relações comerciais, diplomáticas e estratégicas do Brasil com os países africanos pareciam frágeis, com uma diminuição considerável de diplomatas nestes países e deslocamentos para países que galgavam maiores interesses político-econômicos por parte do Estado brasileiro.

Os laços político-econômicos foram (re)constituídos de maneira mais intensa na década de 1970, dentre eles, destacamos a intensificação dos programas de convênio entre universidades que promoveram a vinda de estudantes africanos/as. Resumidamente, significava que a construção de uma nação "moderna", como se espera no processo de modernização, espera/exige uma elite "letrada", a qual terá o aporte necessário para atuar em seus países e no cenário mundial (MOURÃO, 2006), aptos a atuarem na política interna e/ou externa. Essa concepção firmou-se 
nos idos dos anos 1970 e 1980 quando as lutas pela libertação nacional foram lideradas por intelectuais que haviam estudado em países da Europa, como Amílcar Cabral, líder guineense formado em Portugal, Agostinho Neto e Eduardo Mondlane, líderes moçambicanos formados em Portugal e nos EUA, respectivamente.

No Governo Lula (2003-2010) ocorreram significativas mudanças das relações internacionais no intuito de torná-las mais difusas para interpenetrar nações, Estados e culturas, gerando demandas entre os atores sociais e agentes econômicos por uma maior transparência na formulação das políticas externas nacionais (SARAIVA, 1996). A estratégia nesse momento refere-se à assumência da liderança nos programas de cooperação com países africanos lusófonos, especificamente, no que concerne principalmente às áreas de saúde, agricultura e educação.

Vemos que se num determinado contexto, a aproximação junto aos países africanos em questão foi escassa, no final do século $X X$ e início do século $X X I$, acirra-se as disputas das "potências" médias e mundiais por recursos naturais, consumidores e implantação de empresas nacionais e multinacionais. Os países africanos guardam o ranço do neocolonialismo e as consequências culturais e econômicas do processo de modernização retardatária, assim, estabeleceu-se uma nova "arena", como aponta Schützer (2009), em que os principais países do sistema mundial e alguns de segundo escalão como os componentes do BRIC's, estabelecem políticas "soft power" para aproveitarem vantagens políticoeconômicas. $O$ estabelecimento de empresas e o interesse das classes dominantes locais contribuem para a manutenção de desarticulações e a incapacidade do Estado de garantir suas bases socioeconômicas. É assim, com o processo histórico do colonialismo e suas artificialidades, que os países africanos tornam-se presas de interesses em que não se articulam parcerias e consolidação de estruturas que visem o melhoramento de políticas públicas, equiparação no mercado mundial etc. Desse modo,

(...) a lógica neoliberal traz em seu bojo uma gama de práticas que seduzem as classes dominantes e médias de países que procuram a 'modernização' de suas sociedades, com a ideia de acesso fácil às inovações tecnológicas ao custo de uma flexibilização econômica e política em prol do capital internacional (SCHÜTZER, 2009, p.02). 
O processo de modernização nos países africanos é impulsionado pelas estratégias geopolíticas de países ricos e em desenvolvimento, principalmente pelo atrativo crescimento das importações e do PIB. Entre os países que mais intensificaram essas estratégias, tem-se a Alemanha, a Grã-Bretanha, os EUA, a Rússia, a China e o Brasil, apenas para citar alguns. Os EUA possuem interesses militar e econômico, com destaque para a exploração de petróleo e na consolidação de bases militares em diversos pontos de extração do chamado "ouro negro".

A China também tem intensificado relações políticas com diversos países africanos, no que tange ao investimento em áreas ricas em recursos naturais como minérios e no envio de empresas responsáveis pelo reestabelecimento da infraestrutura em países assolados pela guerra civil, como Angola. O Japão também galga interesses no continente africano, primeiramente, enviando remessas humanitárias para a construção de uma rede de relações diplomáticas e a Rússia já declarou ser um de seus principais alvos geopolíticos, rediscutindo a dívida externa, estabelecendo acordos de cooperação com Angola nos setores energético e de minérios; "em outros países possui parcerias nos setores financeiro e bancário, madeireiro, pesqueiro, minerador de diamantes, metalomecânico, de equipamentos agrícolas e de transporte, da indústria alimentar, de defesa, segurança e educação" (SCHÜTZER, 2009, p.07).

São muitos quinhões de "desenvolvimento" propostos e ambicionados pelos países envolvidos, dos quais o Brasil também angaria, especificamente no Governo Lula a partir de 2003, porém com um caráter geopolítico humanista na medida em que o discurso governamental apregoava a dívida política, moral e histórica com o continente africano. Neste mesmo ano, o governo brasileiro fundou mais 12 embaixadas no continente africano e as missões diplomáticas africanas aumentaram e as empresas brasileiras atuam ativamente na exploração das riquezas minerais e obras de infraestrutura, urbana e energética, além disso, a ampliação da capacidade de crédito para o comércio e investimentos a empresários africanos se apresentou como importante incentivo financiador.

O perdão da dívida de Moçambique chegou a 95\%, de acordo com Vargem (2008), com um discurso do governo brasileiro que valoriza a "parceria para o desenvolvimento", enviando instituições brasileiras para oferecerem consultorias técnicas e capacitação de profissionais, inclusive no âmbito educacional com programas como o PEC-G e PEC-PG. Aproximadamente $10 \%$ do PIB de Angola, por 
exemplo, corresponde a empresas brasileiras que oferecem serviços e linhas de crédito que financiam aos compradores angolanos equipamentos brasileiros para obras de infraestrutura e desenvolvimento em que as empresas brasileiras são beneficiadas significativamente. $O$ empresariado brasileiro é quem mais se beneficia das novas relações diplomáticas estabelecidas, assim,

(...) a África constituía um mercado praticamente desconhecido para a quase totalidade dos empresários brasileiros. Nesta conjuntura, o corpo diplomático do Brasil amparou esta relação com todo o apoio logístico necessário, fornecendo a recepção, chancela oficial da operação, facilitação dos tramites burocráticos e acesso a personalidades locais, ou seja, nessa concepção de relações Sul-Sul, com intercâmbio de países emergentes, o Brasil encontra na África um destino para as suas exportações, com empresas estrangeiras e de capital nacional para investir no continente, sobretudo exportadoras de serviços (VARGEM, 2008, p.09).

Desse modo, empresas de alto escalão como Vale do Rio Doce, Norberto Odebrecht, Furnas, Camargo Correa têm se destacado nas áreas de infraestrutura e extração de minérios às custas das reservas naturais de países africanos e, com uma representatividade progressista instala-se uma concepção de ajuda a tais países com uma política missionária civilizacional (RIBEIRO apud VARGEM, 2008).

\subsection{A Educação como mercadoria: qualificação da força de trabalho como necessidade na sociedade atual}

Os acordos bilaterais estabelecidos entre o continente africano e o Brasil abarcam diversas instâncias, todas elas almejando o fortalecimento das trocas comerciais, o estreitamento das relações políticas e econômicas, visando aumento dos níveis de competitividade no sistema mundial produtor de mercadorias. No entanto, a educação tem sido um instigante ponto de análise acerca dos critérios de desenvolvimento e progresso, tão difundidos nos países em desenvolvimento. $O$ objetivo é a busca por uma integração que possa tomar corpo no sistema financeiro mundial e atender aos interesses dos Estados-nações envolvidos por meio do discurso do benefício às sociedades.

A CPLP, com vistas ao incentivo ao desenvolvimento tecnológico e científico, através da Declaração ocorrida em 2009 a partir de uma reunião ordinária, pontua que há um reconhecimento da 
(...) crescente importância das políticas científicas e tecnológicas e de ensino superior para o progresso nacional, e a necessidade de políticas ambiciosas nestes domínios, com vista ao desenvolvimento de sociedades mais qualificadas e inclusivas, em condições de maior e mais equilibrado e sustentável crescimento econômico e social (DECLARAÇÃO DA CPLP, 2009, p.01).

As máximas expressas nos termos crescimento, progresso e desenvolvimento são constantes em qualquer discurso governamental, mas para países em desenvolvimento elas se transformaram em pontos de partida para o alcance de objetivos firmados pelos acordos de cooperação na tentativa de firmar/afirmar que o país, com a ajuda de todos, pode chegar ao topo da concorrência mundial e isso se torna mais fácil se todos os países em desenvolvimento frisarem a importância da união e de uma voz uníssona na corrida por este desenvolvimento.

É importante olharmos o discurso do progresso a partir de uma ótica da crítica a este modelo de desenvolvimento que abarca as esferas do político, econômico e atinge o cultural. Dupas (2006) lembra que a capacidade de produzir mais e melhor, uma das hélices do que se entende por progresso de um país, é recorrente, mas o que não se divulga é que este denominado progresso traz consigo exclusão, concentração de renda e subdesenvolvimento. Segundo ele, a doutrina do progresso acabou se incorporando à filosofia do século XVIII e foi se convertendo em produtos e serviços técnico-científicos que se transformaram em objetos de desejo e símbolos do progresso (BARZUN apud DUPAS, 2006). Na era moderna emergiu os ideais sobre o futuro em conflito com as crenças renascentistas, consideradas atrasadas em detrimento do moderno, considerado como elogio. Desse modo, as novas descobertas passaram a ser fortes marcadores de uma mudança cultural em que sabedoria, enquanto uma categoria iluminista, tornou-se condição a priori para o progresso.

O lluminismo, portanto, com o intuito de romper ideologias acabou criando a ideologia do progresso baseado na importância crescente da ciência e da técnica. Segundo o autor, o livro que melhor simboliza a ideia de desenvolvimento humano a partir das concepções de progresso e liberdade, já introduzindo a visão liberal no sistema econômico de mundo, foi "A riqueza das nações" de Adam Smith, escrito 
ainda no século XVIII, em que ele difundiu a ideia de liberdade econômica como motor de um sistema econômico eficiente para levar ao progresso.

Assim, Smith analisou a historia gradual do progresso econômico da sociedade humana e explorou o conceito de bem-estar como sinônimo de felicidade para o ser humano. Para Smith, "o livre-comércio entre povos e nações seria de grande vantagem para todos e um elemento essencial de sua ideia de progresso" (apud DUPAS, 2006, p.48). As concepções liberais foram fundamentais na construção do conceito de progresso na medida em que ele se forma na evolução do conhecimento e acaba sendo aceito como uma verdade.

Queremos mostrar aqui a maneira como a noção de progresso enquanto verdade, enquanto sinônimo de evolução de uma sociedade está presente nas concepções de civilização, de economia, política e cultura. A educação enquanto uma instância social fundamental também foi atingida pelos ideais de progresso, transformada em critério de legitimidade do desenvolvimento de um Estado, em conhecimento travestido de poder. Nas palavras de Dupas (2006) o processo de ensino contemporâneo, de uma maneira geral, adota hoje o conceito da utilidade pragmática, da funcionalidade por si mesma, enquanto o processo de ensino aprendizagem é relegado a um segundo plano.

No mesmo sentido, Chauí (2003) crítica a reforma ocorrida nas universidades brasileiras no último século que redefiniu o papel do Estado na promoção da educação, saúde e cultura. A educação passa, assim, a ser lotada como serviço não exclusivo do Estado, o que significa que

(...) a educação deixou de ser concebida como um direito e passou a ser considerada um serviço; que a educação deixou de ser considerada um serviço público e passou a ser considerada um serviço que pode ser privado ou privatizado. Mas não só isso. A reforma do Estado definiu a universidade como uma organização social e não como uma instituição social (CHAUÍ, 2003, p.06).

Apresenta-se, a partir da pontuação da autora, o perigo da aplicação de categorias empresariais aos processos de formação nas universidades, contrárias aos ritmos lentos da verdadeira aprendizagem, como salienta Dupas (2006). A universidade torna-se empresa e, como tal, deve responder aos interesses econômicos de quem a sustenta. Em outras palavras, ela se operacionaliza para cumprir objetivos pragmáticos que respondam aos anseios do mercado e do próprio 
Estado que viu na produção do conhecimento uma possibilidade de crescimento do eixo de poder na competitividade mercadológica. É a chamada mercadorização da universidade, já apontada por Santos e Filho (2008) em que

(...)o desinvestimento do Estado na universidade pública e a globalização mercantil da universidade - são as duas faces da mesma moeda. São os dois pilares de um vasto projecto global de política universitária destinado a mudar profundamente 0 modo como o bem público da universidade tem sido produzido, transformando-o num vasto campo de valorização do capitalismo educacional (SANTOS e FILHO, 2008, p. 18).

A universidade lida com a produção de conhecimentos instrumentais úteis na formação de mão de obra qualificada exigida pelo desenvolvimento capitalista. A universidade como empresa produz não apenas para o mercado, mas produz a si mesma como mercado (SANTOS e FILHO, 2008), seja de gestão universitária, de planos de estudo, de certificação, de formação de docentes, de avaliação de docentes e estudantes. Isso nada mais é do que a necessidade de submissão da educação à valorização do Capital, transformando áreas da vida social em mercadorias.

Remetemos-nos à crítica à universidade por se tratar da instancia de nosso interesse no que tange ao processo educativo dos/as estudantes africanos/as presentes nesta investigação. Mas ao falarmos das transformações ocorridas nesta instituição social, não podemos deixar de referir-se à Educação no seu aspecto mais geral, abarcando todos os níveis do ensino, uma vez que se trata de uma instancia social que atinge a toda a sociedade. Kurz (2004) em seu ensaio "Analfabetos secundários" já chamava a atenção para o fato de que até mesmo de universidades e centros de aperfeiçoamento "saem" jovens que não dominam técnicas culturais básicas e incapazes de refletir. Fala-se dos "analfabetos secundários', pessoas que podem ler e escrever em caso de necessidade, mas sem entender e elaborar o conteúdo" (KURZ, 2004, p.14). Este autor pontua-nos que a política e a administração reage às contradições críticas do sistema educacional de três maneiras estereotipadas, a saber: a privatização, a preocupação com a educação da elite e o reducionismo funcionalista da educação.

A privatização, como já se sabe, transforma escolas, centros de ensino e universidades em empresas de mercado e até mesmo as instituições de ensino públicas são atingidas pela lógica do mercado, seja com o aumento de taxas, com o 
financiamento de pesquisas feito por multinacionais e/ou empresas conceituadas. Além disso, a educação da elite torna-se um ponto chave para as universidades públicas em que o Estado é seu maior financiador, assim, contraditoriamente, o Estado financia a educação da classe dominante concentrada, em sua maioria, nas universidades de peso e destaque em ensino e pesquisa.

Desde o final da década de 1980, o ensino superior público tornou-se o mais elitizado e tem aumentado o que Kurz (2011) chama de sua capacidade de valorização econômica imediata. Desse modo, com força cada vez maior, "as escolas e as universidades são atadas diretamente à "economia", guiadas segundo critérios da economia empresarial e, no plano dos conteúdos, dirigidas ao conformismo com o mercado" (KURZ, 2011, p.15).

Para Pinto (2004) o modelo de expansão da educação superior adotado no Brasil, em especial a partir da Reforma Universitária de 1968 (Lei n. 5.540/68), durante a ditadura militar, e intensificado após a aprovação da LDB (Lei n. 9.394/96), no governo Fernando Henrique Cardoso, teve como diretriz a abertura do setor aos agentes do mercado, produzindo uma privatização e mercantilização intensas, uma das maiores do mundo com graves consequências sobre a qualidade do ensino oferecido e sobre a equidade.

Assim, a educação tem um importante papel na ótica neoliberal, na medida em que estreita-se a preparação para o trabalho, para a competitividade do mercado, seja nacional ou internacional, e transmissão do ideal do livre mercado e da livre iniciativa (SILVA, T., 1999). O parâmetro da produtividade e eficiência empresarial são ícones importantes na corrida competitiva para a qualificação da força de trabalho, a qual a universidade tem se prestado como promotora.

O mundo da educação é intrínseco ao mundo do trabalho. Ele tem refletido as novas demandas e transformações ocorridas na sociedade atual em termos de política e economia e 0 que se vê no Brasil é uma espécie de endeusamento/entendimento do ensino superior como responsável pelo desenvolvimento do país, pela qualidade e excelência no ensino, pelo crescimento político, econômico e cultural como um todo. De fato, é inegável que o ensino superior, representado em nosso interesse aqui pela universidade, tem se destacado como um importante estágio de ensino-aprendizagem, de pesquisa e de extensão. 0 aumento do acesso ao ensino superior tem sido um dos maiores ganhos governamentais e sociais nas últimas décadas, apresentando o que tem se 
chamado de democratização do ensino que entendemos como um fator que trouxe, entre outros aspectos, debates importantes sobre a problemática da elitização da educação superior, o aumento desenfreado do número de universidades privadas, o boom das ações afirmativas etc.

Visões otimistas acreditam e depositam no Estado a responsabilidade social perante 0 bom funcionamento da universidade enquanto mantenedora do conhecimento e da inovação. A respeito da necessidade de extensão da pesquisa, do aumento de vagas e da abertura no cenário internacional, Genro (2006) salienta que dessa maneira o Brasil está buscando uma mudança na construção de um projeto de nação, antes (ou ainda) inconcluso. A cooperação internacional é apontada como um carro-chefe na proposição de interesses e negociações compartilhados em escala global. Fala-se, nos dizeres de Gazzola (2006) que a cooperação internacional nos âmbitos das universidades refere-se

(...) a um generoso projeto de mundialização, criando espaço a todos a partir da criação e fortalecimento de blocos regionais, seja com diplomas compartilhados, acolhimento mútuo de alunos, na graduação e na pós-graduação, colaboração científica, tecnológica ou cultural, nas áreas as mais diversas, acordos a propósito de patentes e equipes conjuntas de pesquisas (GAZZOLA, 2006, p.53).

Desse modo, a cooperação internacional nas universidades aparece como uma força que tem se destacado neste cenário atual em que prevalece a política das empresas em detrimento da política dos Estados. Existem metas a serem alcançadas pelas universidades que prezem pela excelência e qualidade de ensino, pesquisa e extensão e, se o conhecimento e a inovação tecnológica são mecanismos de ascensão do Estado brasileiro frente o mercado global. Cabe aqui mencionar, em certa medida, a ação do Estado brasileiro frente ao projeto de desenvolvimento nacional.

Numa leitura geopolítica acerca das causas das dificuldades de desenvolvimento de países fora do sistema-mundo, Lima e Contel (2011) afirmam que sua infraestrutura encontra-se extravertida, ou seja, voltada para os países centrais no favorecimento das exportações e enfraquecimento do mercado interno, utilização de técnicas produtivas importadas que demandam altos custos e pouca utilização de mão-de-obra, pouca capacidade de controle nacional das atividades produtivas, já que quem as comandam são empresas transnacionais, além de 
padrões de ação política importadas em que as elites nacionais adotam modelos externos. Todos esses aspectos foram adotados pelo Estado brasileiro nas décadas de 1960, 1970 e 1980, dentre as quais fragmentou-se os níveis de organização dos bens de produção para três atores, sendo a burguesia nacional a responsável pelos setores industriais tradicionais, como produtos têxteis, bebida, madeira e alimentos, às empresas transnacionais coube as atividades voltadas para a tecnologia como a automobilística e farmacêutica, e, por fim, ao Estado couberam os grandes investimentos com as infraestruturas de transporte, energia e telecomunicações.

Esse caráter de Estado produtor trouxe inúmeras conseqüências para a população do país, sobretudo a de baixa renda que, em nenhum momento, esteve incluída nessa espécie de welfare state e o aumento da dívida externa e interna redefiniu a necessidade de uma reforma estatal na década de 1990 a fim de, entre outros aspectos, redirecionar investimentos para educação e saúde, no entanto, "novas formas de organização das políticas públicas se instala, a favor de poderosos atores privados" (LIMA e CONTEL, 2011, p.34).

A relação entre Estado e ensino superior passa por intensas reformas com a privatização de empresas estatais e o investimento de dinheiro público em instituições privadas, assim, houve um boom de instituições privadas credenciadas e reconhecidas pelo MEC e uma crescente flexibilização do ensino superior (LIMA e CONTEL, 2011) no sentido de que as instituições de ensino superior atendessem às novas velhas exigências da sociedade e do mercado. Assim, essa nova "roupa" do ensino superior brasileiro culminou com mudanças significativas na estrutura curricular dos cursos de graduação, criação de centros universitários voltados para prestação de serviços de educação privada em nível de terceiro grau em que desvincula-se a pesquisa do ensino para atender a consumidores-clientes em universidades mercantis (CALDERON, 2000).

A chamada flexibilização do ensino superior também culminou com sua internacionalização, seja com o crescente fluxo de estudantes brasileiros para 0 exterior e, atualmente, um movimento contrário a esta dinâmica no qual se insere a mobilidade estudantil africana. Os acordos de cooperação bilaterais têm fortalecido o entendimento de que a universidade presta serviços e a insere nas atividades comerciais assim como acontece já no âmbito econômico.

Os interesses econômicos dos países semiperiféricos como é considerado o Brasil tem intensificado a lógica do processo de internacionalização nas IES, com 
um fluxo cada vez maior de estudantes brasileiros para realizar os seus estudos no exterior, principalmente na Europa e nos EUA. A vinda de estudantes estrangeiros para cursarem graduação e pós-graduação nas IES brasileiras é o outro lado dessa mesma perspectiva em que a internacionalização visa o fortalecimento dos acordos de cooperação com outros países da modernização retardatária, como os países lusoafricanos.

Assim, o discurso da qualificação impera como um diferencial na corrida pelo mercado de trabalho e se fortalece, tanto da parte do pais de origem quanto o do pais receptor ao ser evidenciadas pelas universidades brasileiras a excelência no ensino, pesquisa e extensão que, dentre outros aspectos positivos, traz a internacionalização como uma consequência dessa lógica da competição para o trabalho.

Fartes (1998) apresenta a teoria do capital humano como base para o entendimento da corrida pela qualificação como um elemento essencial para o desenvolvimento de um país/estado/nação. A qualificação já se apresentava nas teorias de economistas como Adam Smith ainda no século XVIII, em que já a considerava como um fator de produção. Assim, para os teóricos do desenvolvimento, seja do século XVIII e contemporâneos,

(...) a estreita relação entre qualificação/força de trabalho e crescimento é evidente, na medida em que a aquisição de conhecimentos leva a um aumento de produtividade, à elevação de renda do trabalhador e, consequentemente, ao desenvolvimento da sociedade como um todo (FARTES, 1998, p.213).

Nessa ótica do "capital humano" a qualificação é uma condição sine qua non para o desenvolvimento no sentido até mesmo de explicar, por meio de sua própria lógica, que as diferenças de renda por pessoa e a produtividade são equivalentes ao nível educacional adquirido por um individuo. Assim, para esta assertiva,

(...) ao permitir a aquisição de saberes específicos e o aperfeiçoamento de habilidades necessárias à qualificação para o trabalho, estabelece um vínculo direto entre educação, treinamento, produtividade e acumulação desse capital adquirido na escola" (idem, p.213).

Criticas de cunho marxiano (FRIGOTTO, 1991) foram traçadas sobre esta concepção economicista da educação pautada no chamado capital humano. Este 
autor, embora estivesse atento ao entendimento da educação como formação humana e não apenas no caso do ensino superior que é o nosso foco aqui, em seus mais diferentes níveis, considerava a economia burguesa como estratégia de subordinação dos processos educativos ao capital, reduzindo-os a simples "fator de desenvolvimento".

A internacionalização da economia, o advento de novas tecnologias e meios produtivos que visem o aumento no nível de competição no mercado mundial tem suscitado, nos países modernos retardatários, a exigência de perfis educacionais em que a qualificação aparece como condição fundamental.

O debate sobre a qualificação tem sido amplo nas referências que relacionam a sociologia do trabalho e a educação. Autores como Frigotto (1991), Shiroma e Campos (1997) problematizam a qualificação como habilidade técnica ou o que, atualmente, se compreende por competência. Eles partem de um entendimento da qualificação a partir do contexto da reestruturação produtiva que culminou com o fortalecimento do ensino técnico e incorporou ao ensino ou à educação em si os conceitos empresariais de produtividade, habilidade, competência e melhor desempenho. Nesse sentido, o mercado produz a reificação das qualidades, atributos e capacidades humanas compreendidas como inerentes ao indivíduo e não construídas socialmente (MACHADO apud SHIROMA e CAMPOS, 1997), portanto, o individuo competente é uma exigência e

enquanto atributo pessoal [a competência] se identifica como o ser rentável e o saber competir, a capacidade de pertencer ao mercado por direito, de concorrer e fazer cumprir o objetivo de maximização das condições de venda da própria força de trabalho, mostrando que entre os dois termos - competência e competir - há mais que uma identidade etímica, há identidade com a lógica do capital (MACHADO apud SHIROMA e CAMPOS, 1997, p. 3-4).

Esta assertiva representa, de maneira contundente, a maneira como a concepção empresarial adentra as relações sociais de produção, apresentando comportamentos e habilidades necessárias ao trabalhador que quer vender sua força de trabalho. A nossa preocupação debruça-se na maneira como esta concepção se instala no seio da educação e do ensino, amparando-se no modelo da competência e da qualificação como resultado final.

Embora a qualificação da força de trabalho na literatura sobre educação pauta-se mais precisamente sobre o ensino básico e o ensino técnico numa nuance 
mais aprofundada, salientamos que os cursos de graduação no ensino superior também se prestam a este objetivo, com suas particularidades.

De acordo com Kurz (2011) houve, nos últimos tempos, uma massificação das qualificações superiores que traz um outro problema relativo à desvalorização da força de trabalho qualificado para o mercado de trabalho. Sob esta perspectiva, a formação acadêmica também torna-se precária, apresentando-se, assim, um quadro de discrepância entre a qualificação e as exigências da conjuntura econômica. Neste quadro, algumas "qualificações" estão se tornando supérfluas ou obsoletas, outras em número excessivo de oferta e ainda outras que estão em falta no mercado competitivo. O "proletariado acadêmico" acaba por entrar no jogo do mercado mais uma vez com o abismo entre a qualificação em massa e o emprego.

Ao relatarem suas expectativas de emprego no retorno aos seus países, os/as estudantes africanos/as evidenciam essa contradição estrutural do sistema moderno produtor de mercadorias na relação entre economia e educação. No entanto, por se tratar de uma realidade econômica ainda fragilizada, muitos/as estudantes conseguem adentrar no mercado de trabalho. Segundo G.A., 25 anos, angolano,

(...) o emprego não é uma garantia assim 100\%, mas para as políticas de emprego da Angola, que é meu país, é muito provável que as pessoas cheguem e consigam um emprego. Acho que em menos de 6 (seis) meses você consegue um emprego, dependendo também da área em que você se forma. $\mathrm{Na}$ área de construção civil, medicina há muita oferta porque o país precisa. Agora professores também, de fato os países do Terceiro Mundo têm uma carência de professores, em todas as disciplinas. Às vezes tem formação, mas não tem paciência de estar em sala de aula (G.A., estudante angolano).

A situação socioeconômica de Angola, assim como de outros países lusoafricanos, justifica a ampla oferta de emprego, tanto em áreas tecnológicas, quanto da saúde ou do ensino. Mas é possível perceber aqui aquilo que Kurz (2011) já dizia a respeito da obsolescência das qualificações em massa, quando há um grande numero de formados que não exercem a profissão, seja por falta de emprego ou não-afinidade com a profissão. O estudante J.D.A., 21 anos, ainda aponta para o problema dos vazios demográficos em seu país e o alto índice de êxodo rural que tem levado cada vez mais a população para a capital do país e desmotivado a vinda de profissionais formados no estrangeiro para áreas do interior. 
Em Guiné-Bissau não vou dizer, assim, que tem uma garantia de emprego, mas o país passa por uma situação em que há déficit de profissionais em várias áreas. Então pra quem estudar no estrangeiro, tem $70,80 \%$ de chance pra ele conseguir emprego. Se ele voltar pra lá (Guiné-Bissau) nem vai ser necessário fazer um concurso público, é só apresentar o currículo e o diploma que ele vai ser enquadrado porque ocorre este déficit de profissionais. Mas o governo não dá aquela garantia, o estudante mesmo que tem que procurar, eu estou na área da saúde, daí eu pego meu diploma e tenho de procurar, aí eles podem me colocar em algumas cidades, regiões pra eu trabalhar. Em principio sem essas coisas de apadrinhamento, as pessoas vão sendo direcionadas para outras regiões do país, aí com a progressão na carreira, podem ir pra capital. Na capital aglomeram-se as pessoas e o restante do país fica vazio (J.D.A., estudante guineense).

Este relato é significativo ao apontar a facilidade com que estudantes formados no exterior encontram para exercer suas profissões, no entanto, há uma naturalização da escolha dos mesmos pela capital em detrimento das áreas do interior, o que se torna um problema às autoridades que procuram, de antemão, direcionar os recém-formados para as áreas mais necessitadas. O estudante L.P.N., 23 anos, já pontua a vantagem na formação superior no exterior, dizendo que

(...) não tem uma garantia de emprego, mas a oportunidade de formar fora é vantajosa sim. Alguns que se formaram no Brasil que eu conheço, um se tornou embaixador, outro se formou em Letras e trabalha em um importante órgão em Guiné-Bissau. Outro que se formou em Economia não conseguiu trabalhar no Ministério, porque é muito burocrático e depende de indicações, daí ele foi dar aula na universidade e ele foi fazer mestrado em Lisboa. Nas áreas de Engenharia, telecomunicação, tecnologia em geral você tem mais chance porque há poucos profissionais. Você já chega lá com seu currículo e já arruma emprego. Então minha intenção é essa, voltar pra meu país, ficar perto da família e dar minha contribuição e poder progredir lá, mostrar meu conhecimento (L.P.N., estudante guineense).

Este estudante chama a atenção para o que se considera como sucesso àqueles que estudaram fora de Guiné-Bissau, ocupando importantes cargos, ministrando aulas em universidades locais e, de fato, isso corresponde a um significativo retorno para o país, mas não podemos esquecer que a formação 
superior sozinha não garante a empregabilidade, como já ocorreu com alguns conhecidos por ele. A burocracia e o apadrinhamento ainda se apresentam como barreiras na entrada para o mercado de trabalho. No entanto, quando corresponde a formações técnicas e/ou tecnológicas e da saúde a situação é favorável. Abaixo, verifica-se pelo (gráfico 2) o ingresso de estudantes do PEC-G na Universidade Federal de Goiás de acordo com a área de conhecimento.

Gráfico 2 - Discentes por área de conhecimento que ingressaram pelo PEC -G na UFG de 1993 até 2010

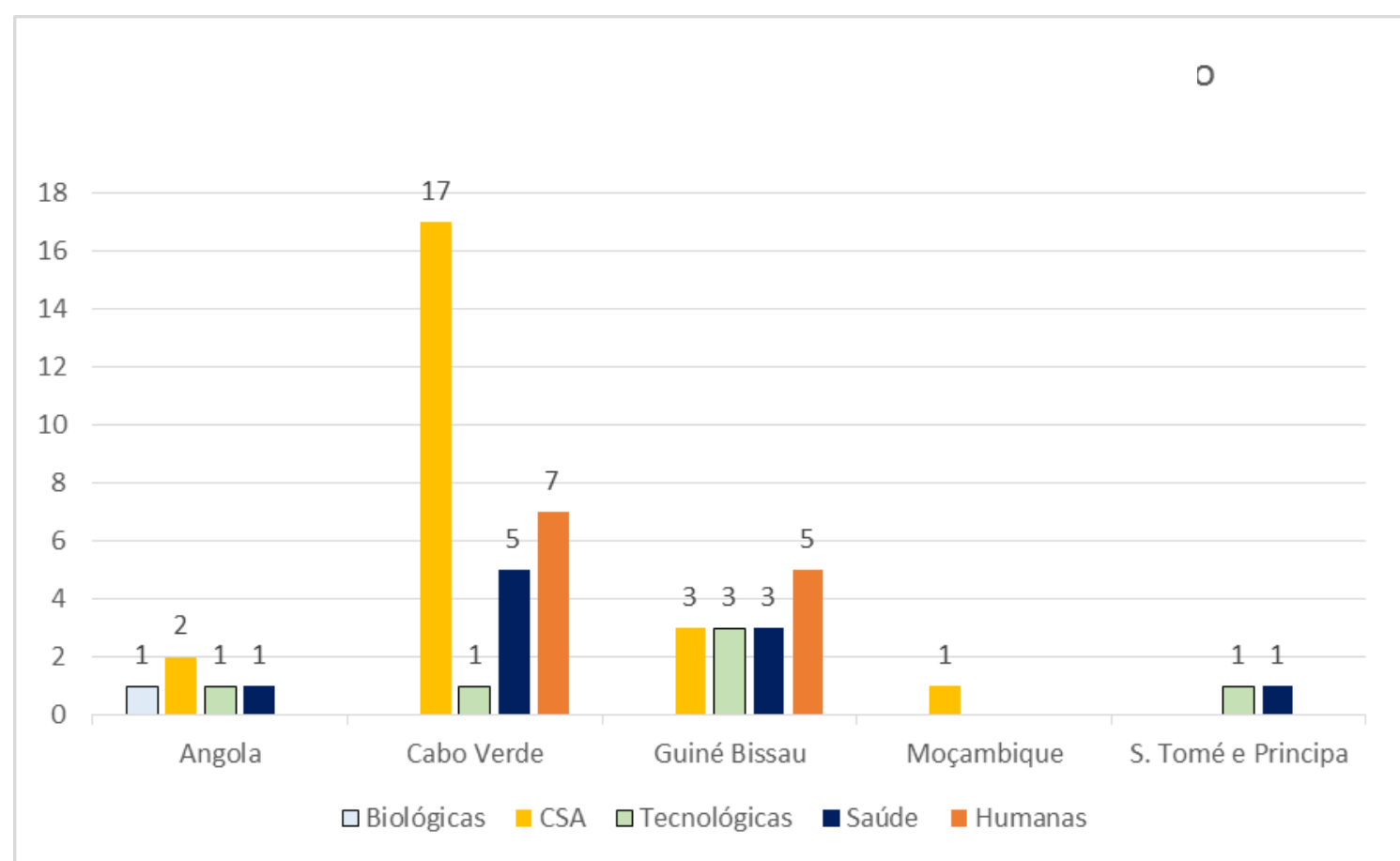

Fonte: Pró-reitoria de graduação, UFG, 2010

Verifica-se que o índice de estudantes da UFG em cursos de Ciências Sociais Aplicadas (CSA) é superior às demais áreas e isso demonstra o que os estudantes relataram quando questionados acerca dos cursos mais procurados pelos ingressantes do PEC-G, destacando-se os cursos de Direito, Administração, Economia e Comunicação Social. As Engenharias e os cursos na área da saúde também estão no topo da lista dos cursos mais procurados e direcionados a estes estudantes.

Desse modo, é importante relembrarmos a subordinação da vida acadêmica à lógica do mercado, que impulsiona a profissionalização da força de trabalho (ANDRIOLI, 2013). Indubitavelmente, existe uma urgência de as universidades 
oferecerem cursos atrativos ao competitivo/concorrido mercado de trabalho e comungar com o discurso da inclusão social ao oferecer o titulo acadêmico.

As ciências humanas, embora haja ainda um considerável contingente de estudantes africanos/as, é relegada a uma constante desvalorização, visto que não oferece o imediatismo da empregabilidade. Muitas discussões são, atualmente, travadas acerca da desvalorização das ciências humanas em detrimento das áreas que envolvem conhecimento tecnológico e matemático ou das que correspondem à saúde, bastante procurada pela grande oferta e altos salários.

Gráfico 3 - Índice de preferência por área de conhecimento de acordo com o país do estudante PEC-G (UFG-2010)

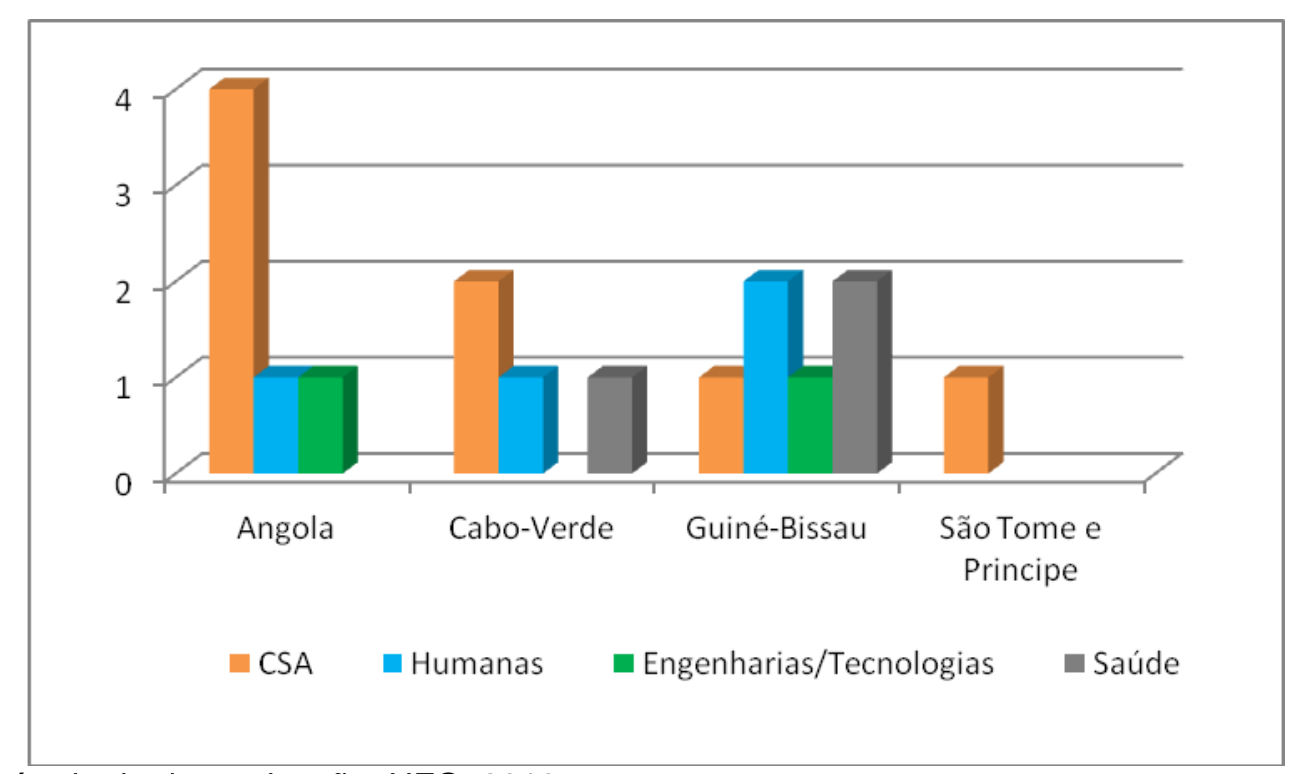

Fonte: Pró-reitoria de graduação, UFG, 2010

Gráfico 4 - Alunos selecionados por área do conhecimento pelo Programa de Estudantes Convênio de graduação- PEC-G (UEG -2002 a 2010)

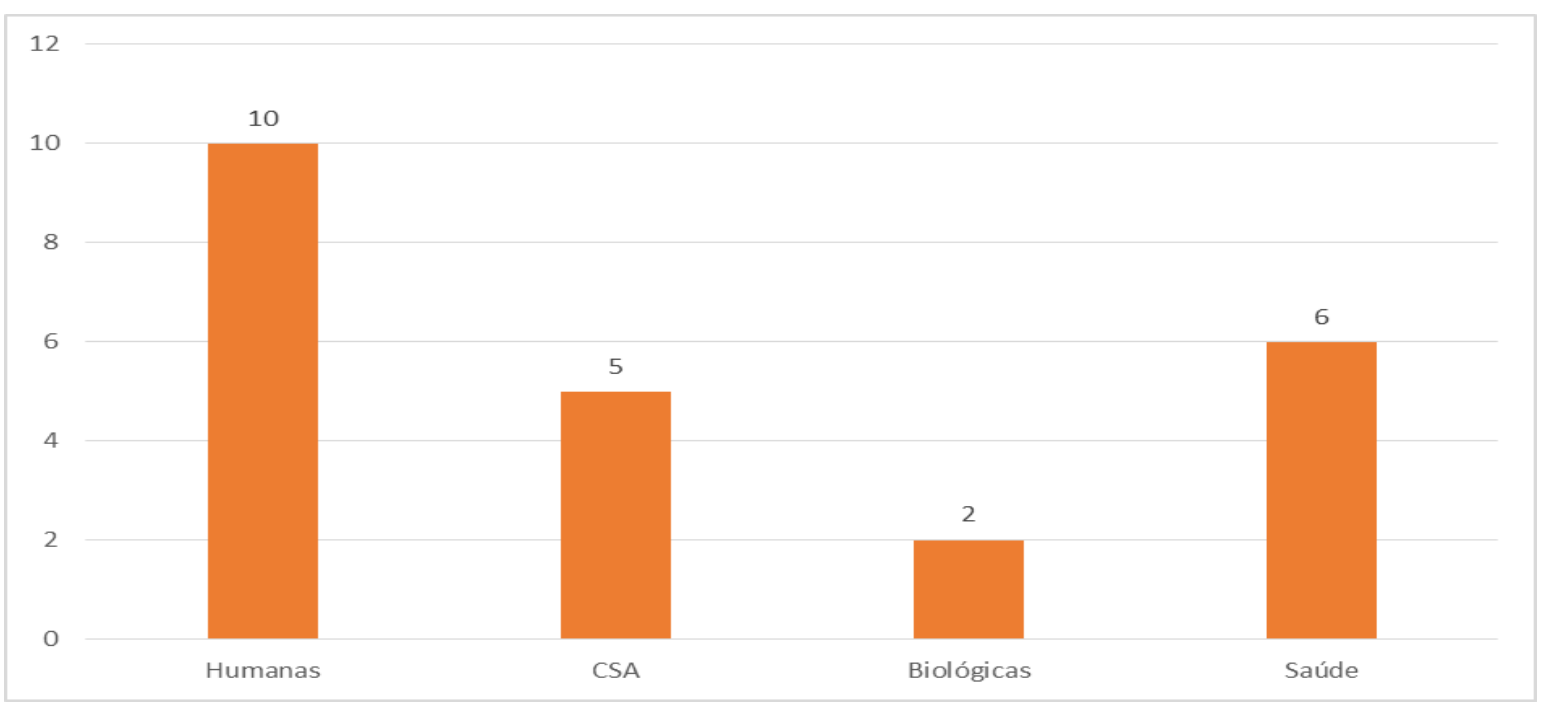

Fonte: Assessoria de Relações Internacionais - UEG, 2010. 
Gráfico 5 - Preferência das áreas de conhecimento de acordo com o país do estudante PEC-G (PUC-2010)

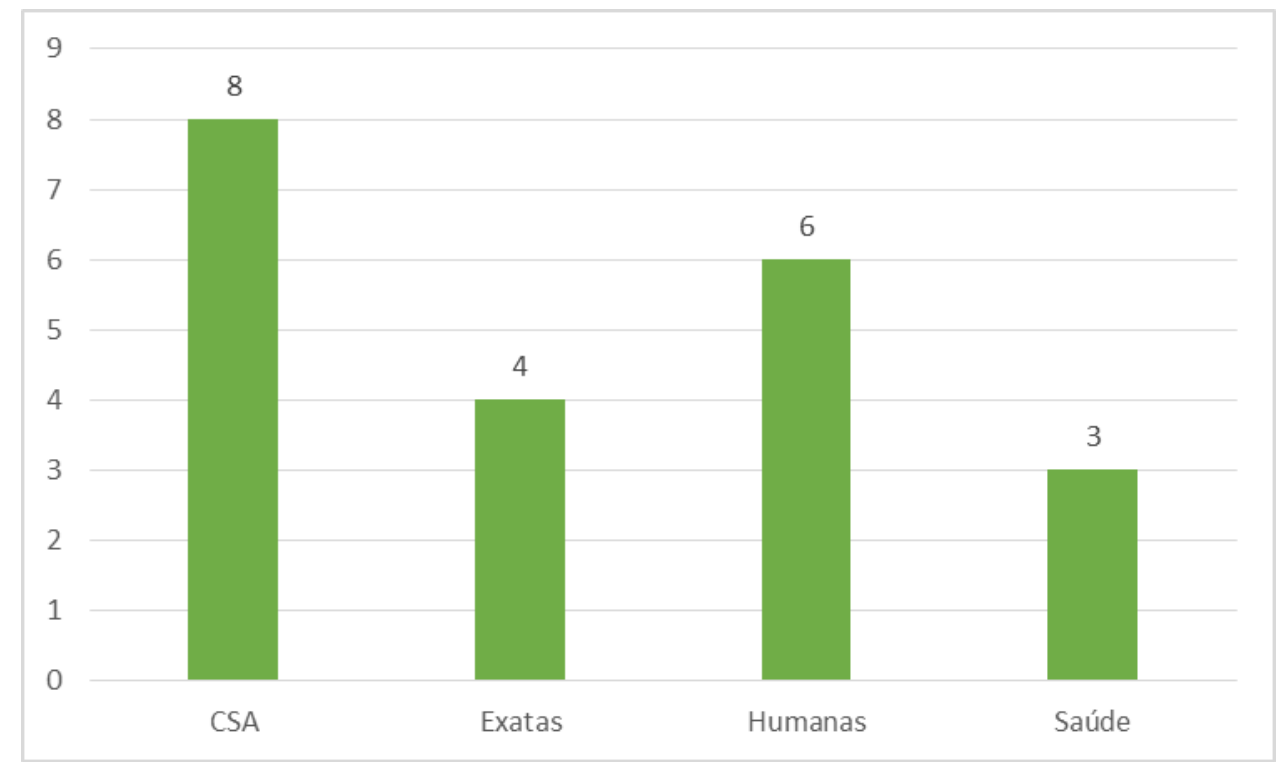

Fonte: ARI-PUC-GO, 2010.

Gráfico 6 - Área do Conhecimento dos cursos frequentados pelos/as entrevistados/as

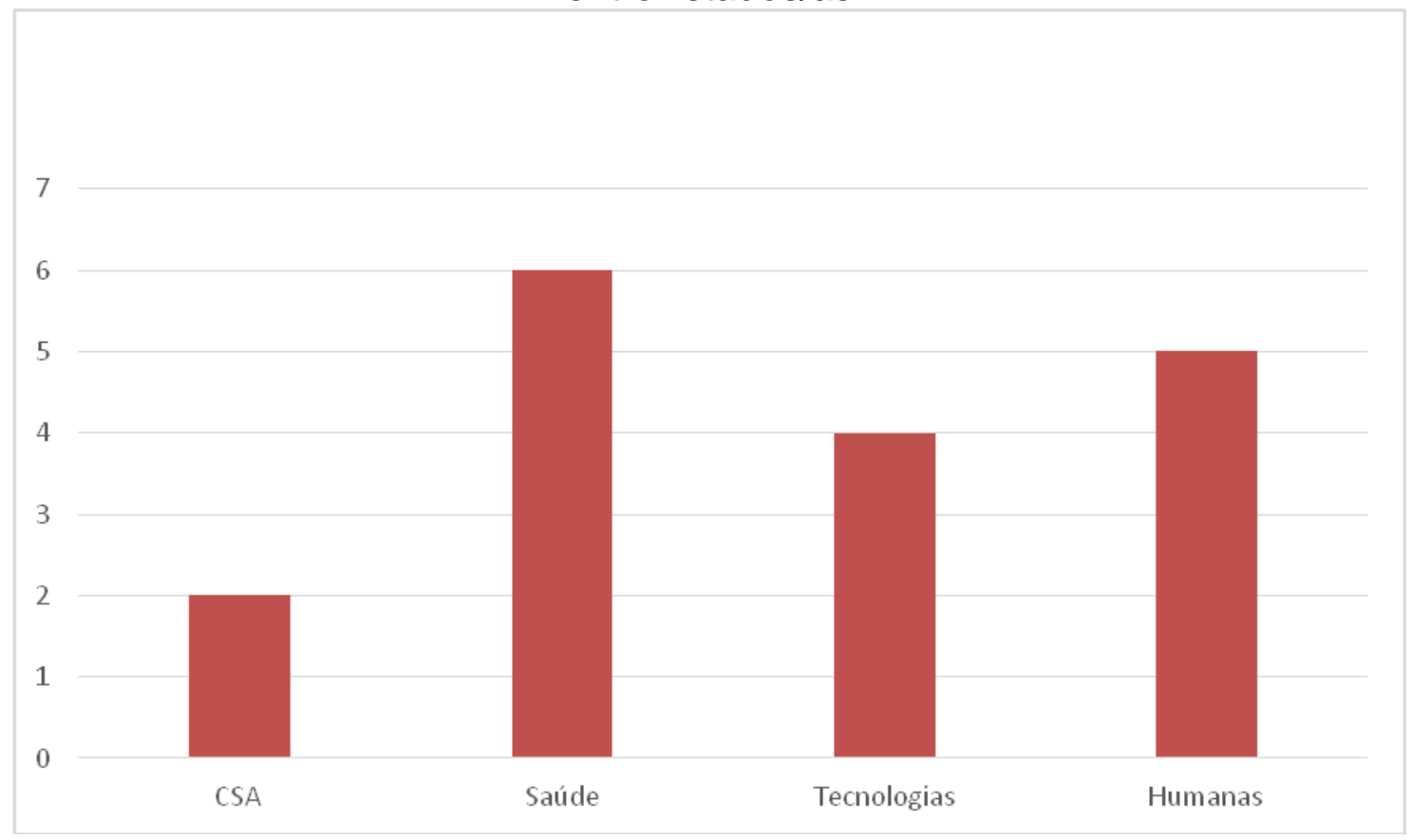

Fonte: entrevista realizada com os/as estudantes africanos/as da UFG, PUC-GO e UEG, 2011.

A partir dos gráficos que representam a escolha por alguns cursos, verifica-se que o ensino superior obedece, assim, à sobrevalorização do pragmatismo, da eficiência meramente técnica e do conformismo. Na visão de Andrioli (2013), 
(...) a idéia é a de que, com uma melhor qualificação técnica, se tenha maiores possibilidades de conseguir um emprego num mercado de trabalho em declínio e é essa a motivação da maioria dos estudantes ao ingressarem na universidade. Em conseqüência a isso, a reflexão sobre os problemas da sociedade assume cada vez menos importância; e valores como engajamento, mobilização social, solidariedade e comunidade perdem seus significados. Importante é o luxo, o lucro, o egocentrismo, a "liberdade do indivíduo" e um lugar no "bem-estar dos poucos" (ANDRIOLI, 2013, p.03).

A possibilidade de conseguir um bom emprego é, indubitavelmente, o grande objetivo destes/as estudantes e não é nossa intenção aqui questionar o entendimento que eles tem a respeito da função utilitarista de sua formação no ensino superior, mas buscar compreender que os/as estudantes universitarios, enquanto um grupo social, têm expectativas e visões de mundo acerca da construção de uma carreira. Como salienta Machado et. al. (2003), os estudantes universitários constituem, atualmente, um segmento da população

particularmente decisivo pelo seu protagonismo social - quer enquanto jovens estudantes, quer nos seus destinos sociais potenciais - e pelo facto de neles se revelarem muitas das dinâmicas de mudança social e cultural mais importantes da actualidade (MACHADO et.al., 2003, p.47).

O ensino universitário torna-se uma expectativa importante em diversas escalas, seja familiar ou profissional, e atinge os segmentos mais estruturais da realidade vivenciada por muitos países a que pertencem os estudantes africanos em questão, pois é esta realidade que os direciona para determinados cursos em detrimento de outros, são as relações interpessoais, a carreira (já existente ou não) são o que determina, em parte, a escolha por um curso, além dos direcionamentos do próprio PEC-G em que muitos acabam cursando de acordo com a disponibilidade de vagas oferecidas pela instituição da cidade ou região.

\subsection{O Programa de Estudantes - Convênio Graduação e Pós Graduação (PEC- G/PEC-PG): cooperação educacional e a meta dos acordos e programas}

Destacamos o fortalecimento de projetos de cooperação que visem a formação profissional de jovens africanos, já estabelecidos desde a década de 1970, 
como o PEC-G (Programa de Estudantes - Convênio de Graduação) e o PEC-PG (Programa de Estudantes - Convênio de Pós-Graduação) nas universidades brasileiras que garantem a formação superior de africanos/as no Brasil. No mapa 2 abaixo, segue a relação dos países africanos que participam do PEC-G.

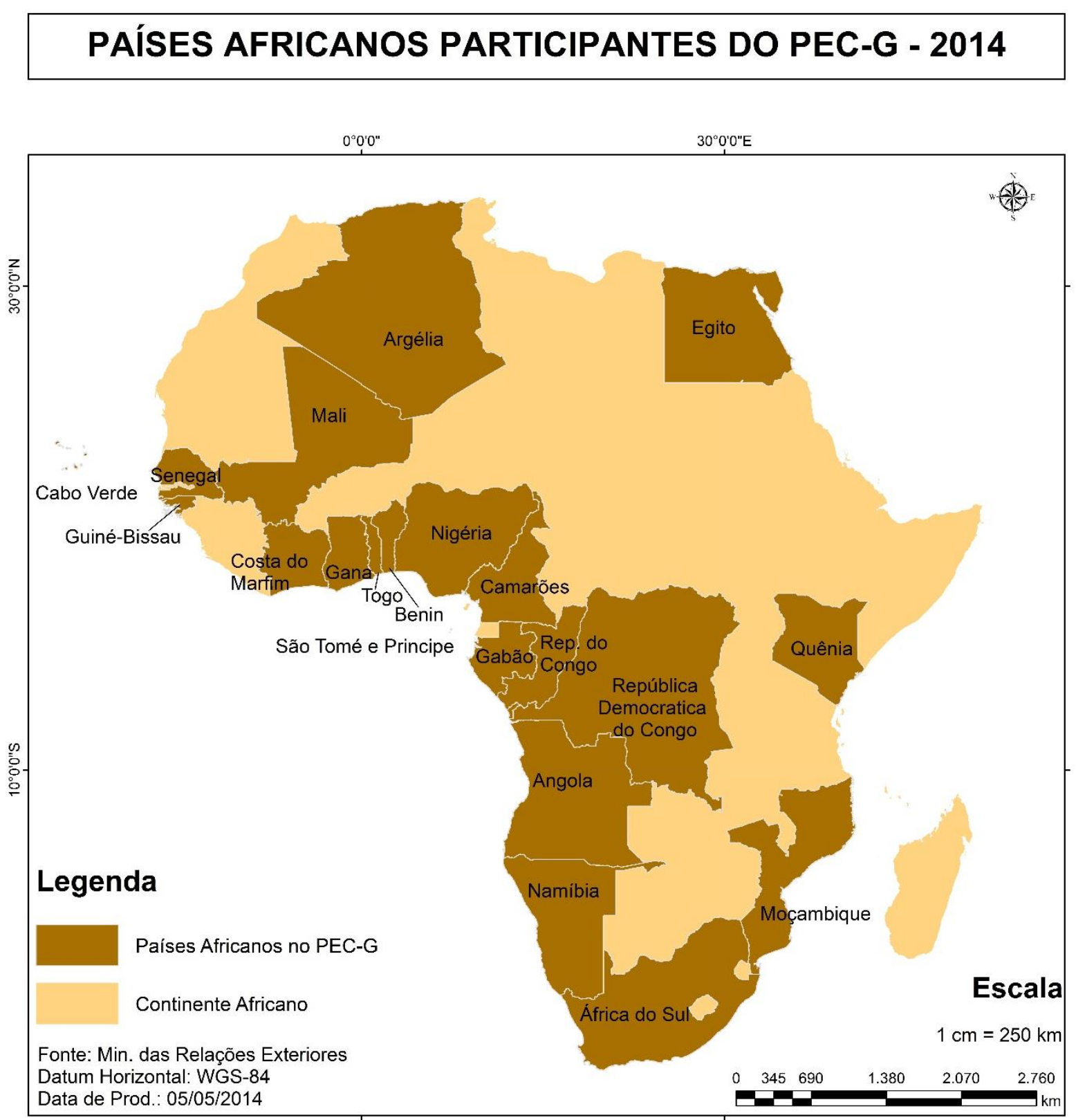

O continente africano é um dos maiores beneficiados com o Programa, em destaque para países como Cabo Verde e Guiné-Bissau que lideram o ranking do índice de estudantes, conforme observado no quadro abaixo. 
Quadro 1- Ranking do índice de estudantes africanos no Brasil (2000-2013)

\begin{tabular}{|c|c|c|c|c|c|c|c|c|c|c|c|c|c|c|c|}
\hline PAIS & 2000 & 2001 & 2002 & 2003 & 2004 & 2005 & 2005 & 2007 & 2008 & 2009 & 2010 & 2011 & 2012 & 2013 & TOTAL \\
\hline Africa do Sul & & & & & & & & & & & & & & & 0 \\
\hline Angola & 3 & 21 & 29 & 23 & 33 & 11 & 31 & 28 & 91 & 68 & 48 & 83 & 61 & 53 & 583 \\
\hline Benin & & & & & & & & & 11 & 5 & 7 & 19 & 40 & 37 & 119 \\
\hline Cabo Verde & 117 & 65 & 227 & 263 & 192 & 230 & 314 & 265 & 381 & 206 & 133 & 76 & 100 & 88 & 2657 \\
\hline Camarões & & & 1 & & & & & 2 & 1 & & 3 & 6 & 4 & 9 & 26 \\
\hline $\begin{array}{l}\text { Costa do } \\
\text { Marfim }\end{array}$ & & & & 1 & 1 & & & 3 & 1 & & & & 1 & 4 & 11 \\
\hline Gabão & & 11 & & 2 & 1 & 1 & 3 & 4 & & & & & & & 22 \\
\hline Gana & 2 & 3 & 7 & 9 & 11 & 6 & 3 & 3 & 6 & & 1 & 1 & & 7 & 59 \\
\hline Guiné-Bissau & 36 & 88 & 111 & 97 & 58 & 186 & 159 & 19 & 133 & 181 & 95 & 55 & 118 & & 1336 \\
\hline Mali & & & & & & & 2 & & & & & & & & 2 \\
\hline Marrocos & & & & & & & & & & & & & & & 0 \\
\hline Moçambique & 12 & 13 & 27 & 21 & 26 & 27 & 13 & 9 & 4 & 4 & 9 & 7 & 6 & 13 & 191 \\
\hline Ilamíbia & 1 & 1 & & & & & & & & & & & & & 2 \\
\hline Iligéria & 9 & 6 & 7 & 11 & 14 & 27 & 19 & 22 & 32 & & & 12 & 1 & 2 & 162 \\
\hline Quênia & & 4 & 14 & 14 & 11 & 12 & 5 & & 6 & 3 & 3 & 3 & & 2 & 77 \\
\hline R. D. Congo & & & & & & & & 9 & 106 & 46 & 78 & 92 & 26 & 19 & 376 \\
\hline Rep. Congo & & & & & & & & & & & & & 4 & 6 & 10 \\
\hline $\begin{array}{l}\text { S. Tomé \& } \\
\text { Príncipe }\end{array}$ & & & 24 & & 47 & 147 & 35 & 13 & 12 & 4 & 6 & 19 & 5 & 3 & 315 \\
\hline Senegal & 7 & 2 & 4 & 1 & 1 & 3 & 5 & 1 & & & & 1 & 1 & 4 & 30 \\
\hline Togo & & & & & & & & & & & & 4 & 11 & 8 & 23 \\
\hline TOTAL & 187 & 214 & 451 & 442 & 395 & 650 & 589 & 378 & 784 & 517 & 383 & 378 & 378 & 255 & 6001 \\
\hline
\end{tabular}

Fonte: www.dce.mre.gov.br. Acesso: em março de 2010.

Pelo que podemos observar no quadro, os maiores contingentes de estudantes africanos/as para IES brasileiras são provenientes de Cabo Verde e Guiné-Bissau. Em seguida, destaca-se Angola, Congo, São Tomé e Príncipe, Moçambique e Benin. Esta constatação reforça o que Hirsch (2007) e Mourão (2006) consideram a respeito da "disposição" caboverdiana para a migração no sentido de que a mobilidade é vista por eles como intrínseca à vida, revelando a construção de um mito de identidade internacionalizada.

Em termos de ingressantes do PEC-G provenientes de países lusoafricanos, tem se destacado o número de caboverdianos conforme apresenta o mapa 3 a seguir, evidenciando o que Hirsch (2007) aponta para a cultura migratória dos mesmos e a forte relação que estabelecem com o Brasil a partir do programa e das redes sociais de familiares e amigos que já experienciaram a migração estudantil. 
Número de Ingressantes por Países nas IES do Estado de Goiás-BRA - 2002/2011

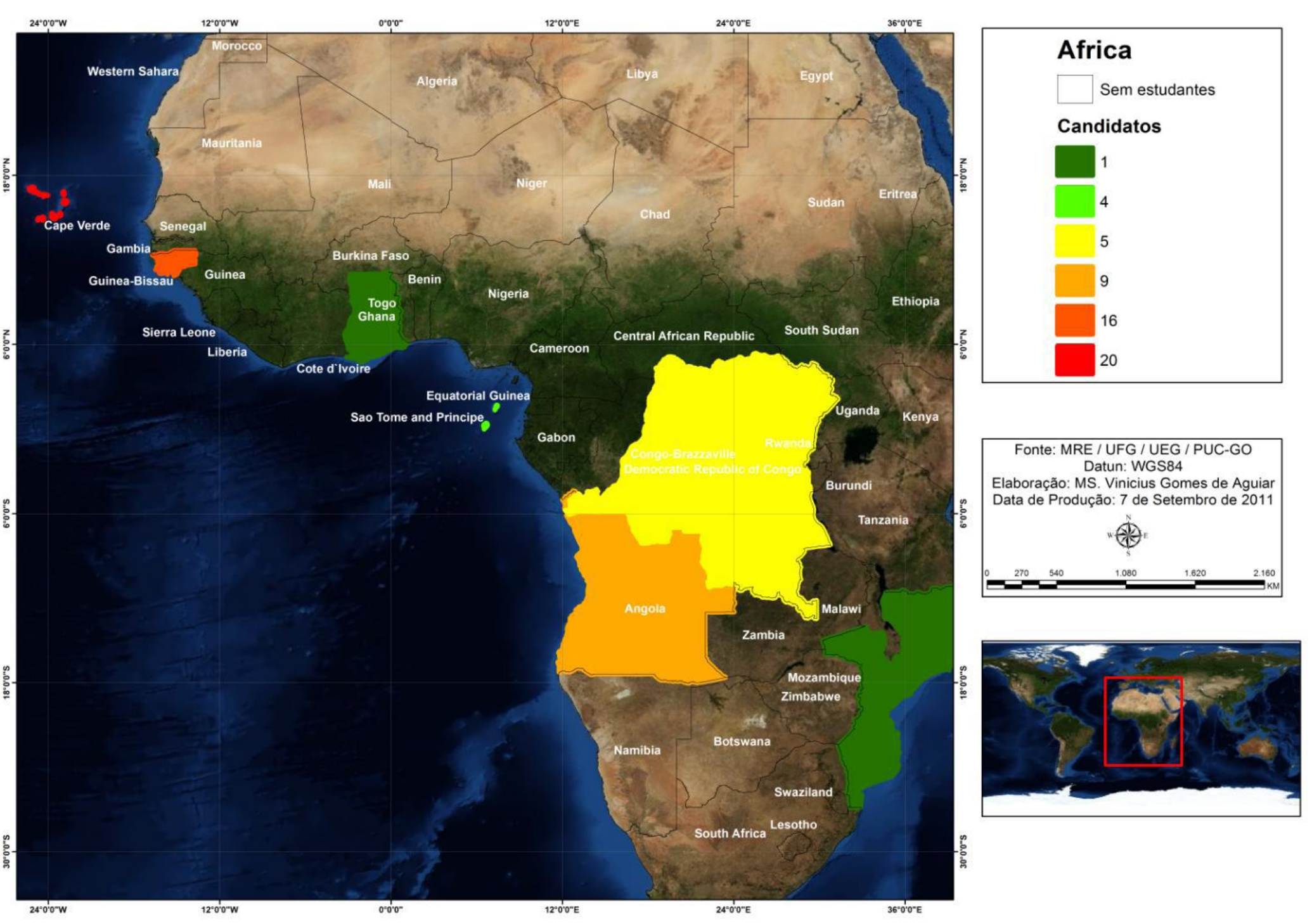


Em matéria do New York Times, Departe (2007), afere-se que cerca de 200 milhões de pessoas vivem fora de Cabo Verde e ajudam a sustentar um número tão grande ou maior nos países em desenvolvimento. Os migrantes enviaram para casa cerca de US\$ 300 bilhões no ano de 2006 - quase três vezes os orçamentos de ajuda internacional mundiais somados. De acordo com a materia, são essas somas que têm ajudado à população construir casas, pagar escolas às crianças e promover pequenas empresas, tornando a migração um ponto central na realidade de Cabo Verde. A migração estudantil caboverdiana também é um fenômeno recorrente e tem sido respaldo para transformações sociopolíticas importantes desde o processo de independência do país.

Além do continente africano, são contemplados alunos da América Latina, que corresponde à maioria, e da Ásia, como mostra o (gráfico 7) a seguir:

Gráfico 7 - Número de países por continente participantes do PEC-G e PG

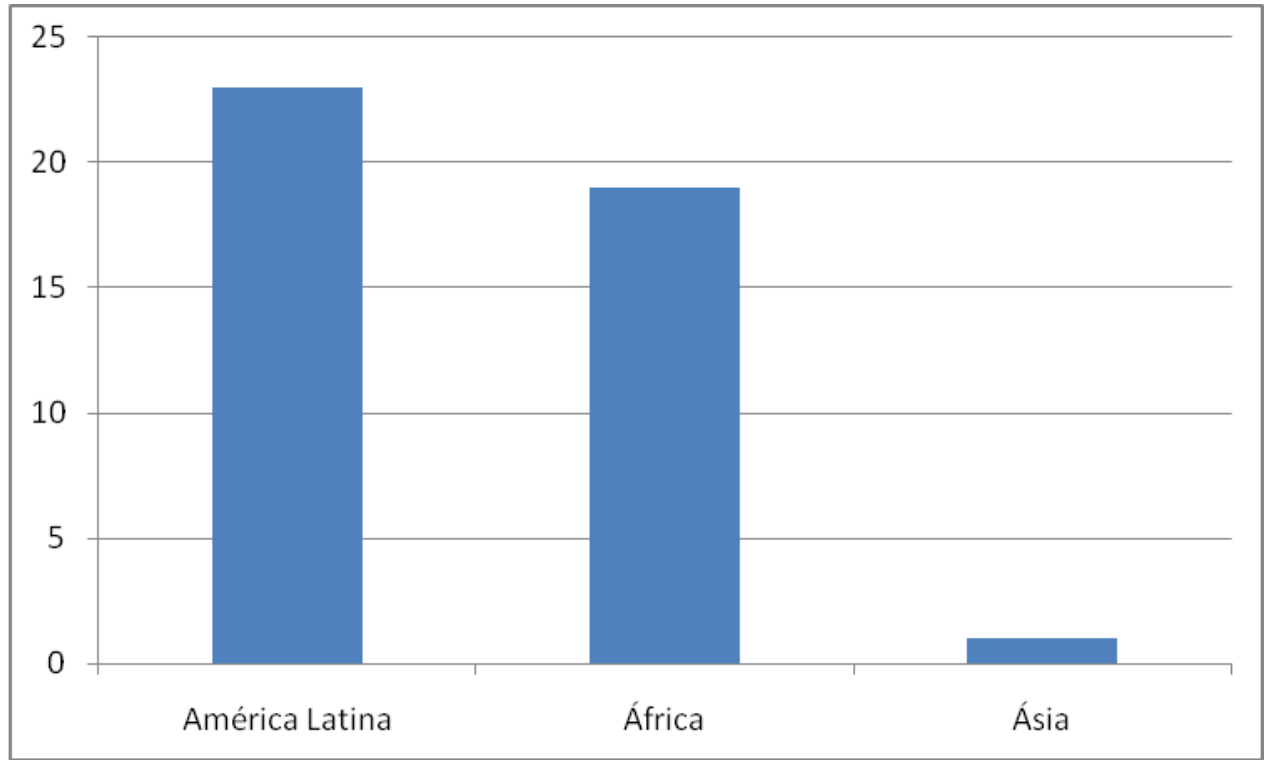

Fonte: Ministério das Relações Exteriores do Brasil, 2012

Os dois convênios supracitados representam a principal porta de entrada de estudantes africanos no Brasil, portanto, de suma importância para nossas investigações, também porque todos/as os/as estudantes contactados/as nesta pesquisa são provenientes do PEC-G e PG.

O Programa de Estudantes-Convênio de Graduação (PEC-G) foi criado para servir de amparo aos estudantes estrangeiros junto às universidades brasileiras, bem como para regulamentar a permanência dos mesmos no Brasil. De acordo com 
o Ministério das Relações Exteriores (2010), o primeiro protocolo do PEC-G foi lançado em 1965 para oferecer vagas em IES brasileiras para candidatos de países em desenvolvimento com os quais o Brasil mantém acordos bilaterais de cooperação educacional e/ou cultural. Atualmente o programa é regido pelo Decreto Presidencial n. 7948, publicado em 2013, que versa sobre o oferecimento de vagas em diversas instituições de ensino superior, conforme mapa 4:

\section{IES Brasileiras Participantes do PEC-G (2014)}

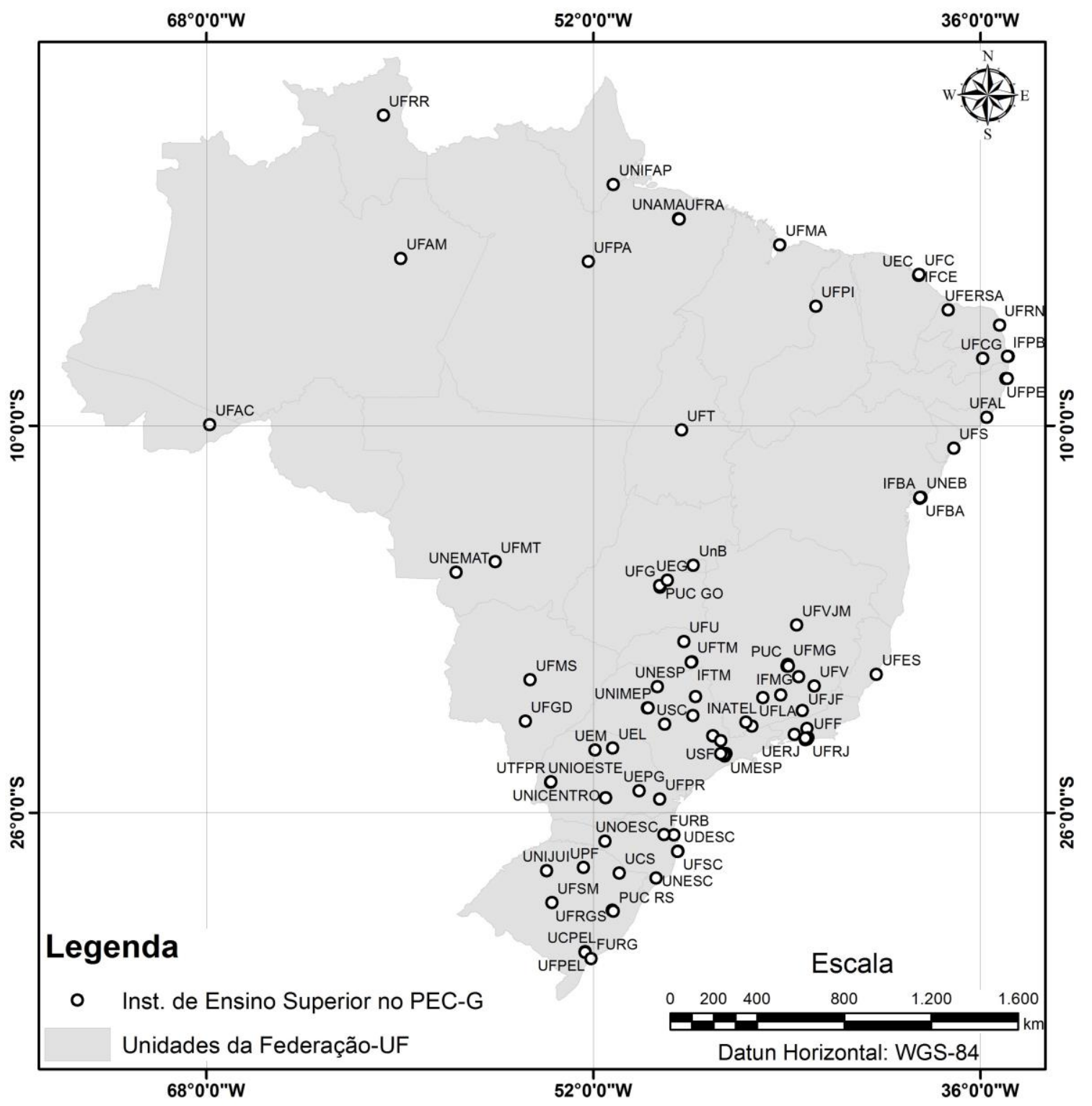

Fonte: www.dce.mre.gov.br, 2014

São oferecidas vagas nas IES brasileiras sem custo de matrícula e sem necessidade de prestar o vestibular. O/a estudante deve estar ciente das normas e 
regulamentos do programa, assumindo ser conivente com as exigências e condições impostas pelo mesmo. O governo brasileiro disponibiliza no sítio do Ministério das Relações Exteriores um manual de orientações ao ingressante no programa em que são evidenciadas questões fundamentais para sua estadia e permanência, seja com relação a documentos a serem providenciados, informações sobre o Brasil e cada uma das regiões brasileiras e principais cidades, informações gerais sobre adaptação no país, dentre outros aspectos. Este manual constitui-se como o principal documento, além do decreto que rege o programa, de apoio ao estudante convênio, visto que ao chegar nas universidades de destino pouco ou nada é feito para assegurar a estadia e adaptação dos mesmos. Como lembra Mungoi (2007) na maioria das vezes, ninguém os recebe no aeroporto ou rodoviária e muitos chegam a viajar sem nenhuma indicação prévia a respeito de hospedagem e pouca quantia em dinheiro para esse fim. Muitos não sabem para onde ir, com quem falar e nem como tratar da documentação necessária, o que nos leva a crer que as instituições não apresentam políticas "eficazes" ou efetivas de orientação e apoio aos estudantes do PEC-G/PG, enquanto as coordenadorias de relações internacionais destas instituições em questão - UFG, UEG e PUC-GO - estão voltadas aos alunos intercambistas e à promoção/divulgação de programas de intercâmbio para a Europa, Canadá e EUA, principalmente.

Alguns depoimentos de G.A, 25 anos, angolano e J.D.A., 21 anos, guineense, pressupõem uma diferenciação de tratamento com relação a estudantes de outros países fora do continente africano, o que será melhor evidenciado no capítulo posterior acerca das considerações a respeito do sentir-se estrangeiro/a e negro/a relatado pelos/as estudantes.

Ao evidenciar o relato/queixa destes estudantes, poderíamos pensar ou nos inquietarmos com a diferença de tratamento dado ao que é chamado "gringo". Os garotos relembram que eles não possuem as "vantagens" de serem "gringos", seja nos círculos de convívio (rua e lazer) ou na universidade. Na rua, todos os meninos africanos já foram abordados por policiais de maneira violenta e só reconhecidos como estrangeiros e estudantes depois que "abriram a boca" e, nas universidades, não são sequer apresentados como alunos de "intercâmbio" ou orientados pela instituição. O que as instituições alegam, ao serem questionadas acerca do acolhimento ao estudante estrangeiro, se contradiz com os relatos dos mesmos, e, muitas vezes, se concretiza apenas nos manuais de orientação já distribuídos pelo 
próprio Ministério das Relações Exteriores ao Estudante convênio PEC-G/PG. Ao relembrarem que, certa feita, até mesmo um veículo institucional já foi deslocado para receber um estudante da América do Sul no aeroporto, G.A. e J.D.A. estão denunciando a negligência institucional e, em palavras mais severas, o racismo institucional.

O racismo institucional, de acordo com Rex (apud SANTOS, I., 2012) revelase através de mecanismos e estratégias que dificultam a presença ou permanência dos negros numa determinada instituição. Ele se manifesta quando uma instituição cria um fator de discriminação, mas não o reconhece formalmente. Assim,

(...) o problema não é demonstrar a existência de ideologia e doutrinas que as pessoas utilizam para justificar suas ações. É no funcionamento da sociedade na qual o racismo constitui uma propriedade estrutural inscrita nos mecanismos rotineiros, assegurando a dominação e a inferiorização dos negros, sem que haja necessidade de teorizar ou de tentar justifica-los pela ciência (SANTOS, I., 2012, p. 20).

Torna-se uma questão delicada e complexa a afirmação da existência do racismo institucional nas universidades receptoras, mas como uma instituição social, a universidade representa o modus operandi social que é marcado pelo racismo e por demais discriminações. Nos baseamos nos relatos dos/as estudantes que, mais do que denúncia, demonstram uma percepção própria a respeito do tratamento e das relações que engendram o meio acadêmico. O racismo institucional, por certo, é um mecanismo de geração de hierarquias por meio de práticas consideradas neutras ou universalistas que controlam os espaços e os serviços oferecidos.

As universidades em questão, ao negligenciarem, seja com a falta de informação e orientação, seja na diferença de tratamento se comparado a outros/as alunos/as estrangeiros/as, dão margem a um entendimento sobre a perpetuação do racismo institucional. Claro que estamos nos referindo a um mecanismo de discriminação profundamente eficaz que tem dificultado a acesso a bens e serviços à população negra, tem tratado-a de maneira desigual nos âmbitos também do gênero e da geração e não é nosso intuito tratar desses referenciais para a compreensão do nosso estudo.

O racismo institucional ainda é uma discussão pouco estudada no próprio debate sobre as relações raciais e a afirmação de sua manifestação ou presença ainda é um terreno duvidoso e escorregadio. Estamos pontuando uma problemática que envolve a percepção dos/as estudantes africanos/as frente às universidades de 
acolhida, embora seja visível algumas promoções de interação com o estudante via instituição, realização de workshops para "ambientar" os/as estudantes e promover trocas de experiências e convívio "cultural".

O trabalho das universidades em questão frente à recepção dos/as estrangeiros/as, em alguns momentos, parece existir de maneira mais contundente ao visualizarmos o Manual do Estudante Estrangeiro disponível no próprio sítio. Nesse caso, a UFG apresenta informações importantes no que tange à chegada e estadia do estudante, como demonstram os quadros a seguir:

Quadro 2 - Hotéis em Goiânia de acordo com o Manual do Estudante Estrangeiro

\begin{tabular}{|l|l|}
\hline \multicolumn{2}{|c|}{ Hotéis* - Preço Estimado da Diária } \\
\hline$\star$ & $\mathrm{R} \$ 95,00$ \\
\hline$\star \star$ & $\mathrm{R} \$ 106,00$ \\
\hline$\star \star \star$ & $\mathrm{R} \$ 112,00$ \\
\hline$\star \star \star \star$ & $\mathrm{R} \$ 146,00$ \\
\hline$\star \star \star \star \star$ & $\mathrm{R} \$ 272,00$ \\
\hline$*$ Para lista de hotéis: \\
www.a-brasil.com/hotelesgoiania/ \\
www.hospedevip.com.br/goiania/hoteis-em-goiania.html \\
\hline
\end{tabular}

Dados consultados entre os dias 9 e 12 de maio de 2011.

Fonte: www.cai.ufg.br, 2012.

Quadro 3 - Aluguel em Goiânia conforme o Manual do Estudante Estrangeiro

\begin{tabular}{|l|l|l|}
\hline \multicolumn{2}{|c|}{ Aluguel - Preço estimado por mês } \\
\hline Localização & Preço \\
\hline $\begin{array}{l}\text { Praça Universitária - } \\
\text { Próximo ao Câmpus } \\
\text { Colemar Natal e } \\
\text { Silva. }\end{array}$ & Apartamento & R\$ 600,00 \\
\cline { 2 - 3 } & Casa (2 quartos) & R\$ 1300,00 \\
\cline { 2 - 3 } & $\begin{array}{l}\text { Quitinete (Apartamento } \\
\text { Costudantil) }\end{array}$ & R\$ 500,00 \\
\hline $\begin{array}{l}\text { Próximo ao Câmpus Itatiaia - } \\
\text { Samambaia }\end{array}$ & Apartamento & R\$ 500,00 \\
\cline { 2 - 3 } & Casa & R\$ 550,00 \\
\cline { 2 - 3 } & $\begin{array}{l}\text { Quitinete (Apartamento } \\
\text { estudantil) }\end{array}$ & RS 50,00 \\
\hline Setor Central & Apartamento & R\$ 400,00,00 \\
\cline { 2 - 3 } & Casa & \\
\cline { 2 - 3 } & $\begin{array}{l}\text { Quitinete (Apartamento } \\
\text { estudantil) }\end{array}$ \\
\hline
\end{tabular}

Dados consultados entre os dias 9 e 12 de maio de 2011.

Fonte: www.cai.ufg.br, 2012. 
Quadro 4 - Transporte em Goiânia, segundo o Manual do Estudante Estrangeiro

\begin{tabular}{|l|l|}
\hline \multicolumn{2}{|c|}{ Transporte } \\
\hline Para se locomover é necessário comprar o bilhete (Sitpass) \\
em um ponto de venda antecipadamente. No Câmpus \\
Samambaia pode-se comprar no DCE. \\
\hline Passagem de ônibus & $\mathrm{R} \$ 2,50$ Inteira \\
\cline { 2 - 2 } & $\mathrm{R} \$ 1,25$ Passe estudantil* \\
\cline { 2 - 2 } & $\mathrm{R} \$ 1,15$ Eixo Anhanguera \\
\cline { 2 - 2 } & $\begin{array}{l}\mathrm{R} \$ 6,00 \text { Rede Citybus } \\
\text { www.citybus.com.br }\end{array}$ \\
\hline * É necessário fazer o cadastro no Setransp. www.sitpass.com.br \\
\hline
\end{tabular}

Dados consultados entre os dias 15 e 20 de maio de 2011.

Fonte: www.cai.ufg.br, 2012.

Quadro 5 - Custo de vida em Goiânia conforme o Manual do Estudante Estrangeiro

\begin{tabular}{|c|c|c|c|c|c|c|}
\hline \multicolumn{7}{|c|}{ Custo de Vida em Goiânia } \\
\hline \multirow[t]{2}{*}{ Produtos } & \multirow[t]{2}{*}{ Quantidades } & \multicolumn{2}{|l|}{ Gasto Mensal } & \multirow{2}{*}{$\begin{array}{l}\text { Variação Anual } \\
\%\end{array}$} & \multicolumn{2}{|c|}{ Tempo de Trabalho (1) } \\
\hline & & $\begin{array}{l}\text { Dezembro de } 2009 \\
\text { RS }\end{array}$ & $\begin{array}{l}\text { Dezembro de } 2010 \\
\text { R\$ }\end{array}$ & & Dezembro de 2009 & \begin{tabular}{|l} 
Dezembro de \\
2010
\end{tabular} \\
\hline Carne & $6 \mathrm{~kg}$ & 83,64 & 72,66 & $-13,13$ & $39 \mathrm{~h} 34$ & $31 \mathrm{~h} 21 \mathrm{~m}$ \\
\hline Leite & 7,51 & 11,03 & 11,10 & 0,63 & $5 \mathrm{~h} 13 \mathrm{~m}$ & $4 \mathrm{~h} 47 \mathrm{~m}$ \\
\hline Feijão & $4,5 \mathrm{~kg}$ & 20,88 & 13,37 & $-35,97$ & $9 \mathrm{~h} 53 \mathrm{~m}$ & $5 \mathrm{~h} 46 \mathrm{~m}$ \\
\hline Arroz & $3 \mathrm{~kg}$ & 6,18 & 5,88 & $-4,85$ & $2 \mathrm{~h} 55 \mathrm{~m}$ & $2 \mathrm{~h} 32 \mathrm{~m}$ \\
\hline Farinha & $1,5 \mathrm{~kg}$ & 3,33 & 3,26 & $-2,10$ & $1 \mathrm{~h} 35 \mathrm{~m}$ & $1 \mathrm{~h} 24 \mathrm{~m}$ \\
\hline Batata & $6 \mathrm{~kg}$ & 9,78 & 12,54 & 28,22 & $4 \mathrm{~h} 38 \mathrm{~m}$ & $5 \mathrm{~h} 25 \mathrm{~m}$ \\
\hline Tomate & $9 \mathrm{~kg}$ & 23,13 & 21,51 & $-7,00$ & $10 \mathrm{~h} 57 \mathrm{~m}$ & $9 \mathrm{~h} 17 \mathrm{~m}$ \\
\hline Pão & $6 \mathrm{~kg}$ & 36,12 & 35,28 & $-2,33$ & $17 \mathrm{~h} 05 \mathrm{~m}$ & $15 \mathrm{~h} 13 \mathrm{~m}$ \\
\hline Café & $600 \mathrm{~g}$ & 6,52 & 6,53 & 0,15 & $3 \mathrm{~h} 05 \mathrm{~m}$ & $2 \mathrm{~h} 49 \mathrm{~m}$ \\
\hline Banana & $7,5 \mathrm{dz}$ & 11,33 & 13,50 & 19,15 & $5 \mathrm{~h} 22 \mathrm{~m}$ & $5 \mathrm{~h} 49 \mathrm{~m}$ \\
\hline Açúcar & $3 \mathrm{~kg}$ & 4,92 & 6,93 & 40,85 & $2 \mathrm{~h} 20 \mathrm{~m}$ & $2 \mathrm{~h} 59 \mathrm{~m}$ \\
\hline Óleo & $900 \mathrm{ml}$ & 2,55 & 2,47 & $-3,14$ & $1 \mathrm{~h} 12 \mathrm{~m}$ & $1 \mathrm{~h} 04 \mathrm{~m}$ \\
\hline Manteiga & $750 \mathrm{~g}$ & 11,72 & 11,86 & 1,19 & $5 \mathrm{~h} 33 \mathrm{~m}$ & $5 \mathrm{~h} 07 \mathrm{~m}$ \\
\hline Total da Cesta & & 231,13 & 216,89 & $-6,16$ & $109 \mathrm{~h} 21 \mathrm{~m}$ & $93 \mathrm{~h} 34 \mathrm{~m}$ \\
\hline
\end{tabular}

Dados consultados entre os dias 9 e 12 de maio de 2011.

Fonte: www.cai.ufg.br, 2012.

Tais informações são importantes para um primeiro contato com a realidade local. O preço dos hotéis e do aluguel próximo aos campi universitários indica que é preciso estar munido de uma considerável soma em dinheiro na chegada, indicando um caminho para que possam planejar sua estadia com calma num segundo momento. $\mathrm{O}$ intrigante é que a disponibilidade deste guia é restrita ao site e é 
preciso procurar muito nos links disponíveis dentro do sítio da Coordenadoria de Assuntos Internacionais para encontra-lo. Vê-se que o guia, apesar de sua utilidade a qualquer estudante estrangeiro ingressante na UFG, é direcionado implicitamente ao estudante intercambistas que não participam do PEC-G e disponibilizado apenas no sítio.

A UEG apresenta uma chamada no sítio disponível ao estudante estrangeiro apenas para informações mais gerais a respeito da própria universidade, ao salientar que está aberta a alunos do mundo todo através de convênios de intercâmbio, que existe o compromisso com acordos de cooperação internacional a fim de ampliar horizontes e buscar parcerias, além de afirmar que:

Auxiliamos os alunos e professores de outros países na sua
chegada à universidade e em todo o período de sua estadia no
Brasil. Damos orientações sobre os órgãos públicos a serem
procurados para a regularização de documentos e demais
procedimentos burocráticos. Da mesma maneira, buscamos
dar todo o apoio durante a vida acadêmica do estrangeiro,
estando sempre à disposição para eventuais dúvidas ou
dificuldades durante o período de intercâmbio. Temos
informações sobre aspectos como: alimentação, hospedagem,
locais para lazer, hospitais e demais serviços disponíveis na
cidade onde o intercambista vai morar (disponível em:
www.cgri.ueg.br, 2011).

Ao que tudo indica as informações detalhadas a respeito da chegada ao Brasil e à UEG só devem/podem ser conseguidas mediante consulta pela internet ou apresentação presencial do/a estudante à Coordenadoria de Relações Internacionais da mesma, o que dificulta o acesso rápido à informação, principalmente, porque se trata de um órgão que funciona nas mediações da reitoria, o acesso à mesma só pode ser feito com automóvel ou coletivo urbano da cidade de Anápolis, sendo que alguns estudantes estrangeiros estão destinados a outros pólos situados longe de Anápolis, cidade-sede da UEG, alguns moram em Goiânia, localizada a $60 \mathrm{~km}$ de Anápolis.

Quem não mora próximo ao prédio da reitoria fica impossibilitado de receber tais informações de maneira mais rápida. No sitio ainda podemos ver uma série de informativos a respeito da qualidade e bom funcionamento da universidade como uma "chamada" aos/às estudantes estrangeiros/as:

A UEG possui infraestrutura completa, com laboratórios, salas de aula, grupos de pesquisa, auditórios, praça de alimentação, 
serviços bancários, centro esportivos e bibliotecas. Além disso, contamos com professores altamente capacitados nas diversas áreas de ensino, fornecendo condições para que os professores e alunos estrangeiros tenham acesso a um ensino e uma prática universitária de qualidade (disponível em: www.cgri.ueg.br, 2011)

O fato de a universidade apresentar tais dizeres nos sítios de divulgação não é suficiente para ambientar os/as estudantes, aproximá-los da realidade de cada pólo e o mascaramento das reais condições, da precariedade e não prioridade à recepção de estrangeiros/as não é evidenciada nos meios de comunicação. No entanto, ao aproximarmos de alguns funcionários e dos estudantes, vê-se que a negligência fere de maneira considerável a permanência dos/as estudantes africanos/as.

A PUC não apresenta sequer informações gerais via internet para o estudante convênio PEC-G/PG a respeito da cidade, moradia ou alimentação. A Coordenadoria de Assuntos Estudantis é encarregada de prestar assistência a todos/as os/as estudantes, mas no sítio não há qualquer referência ao estudanteconvênio ingressante, nem sobre o PEC-G.

Uma questão que também se apresenta como um impasse aos ingressantes do programa é a dificuldade em conseguir bolsas de estudos, seja do governo de seus países, seja do governo brasileiro. Com o passar dos anos em graduação, o/a estudante pode receber bolsa de estudo do governo brasileiro, mas são casos específicos e, muitas vezes, o beneficio é concedido já na metade ou final da graduação.

Segundo o Departamento de Temas Educacionais do Ministério das Relações Exteriores, há 03 (três) tipos de bolsa concedidas pelo período de um semestre passível de renovação:

- Bolsa Mérito: concedida a estudantes-convênio que apresentem notável rendimento acadêmico. Além de bolsa mensal, o bolsista Mérito recebe passagem aérea de retorno ao seu país, após o término da graduação.

- Bolsa MRE: dada a estudantes-convênio de instituições não federais que apresentem debilitada situação financeira após um ano de permanência no Brasil.

- Bolsa Emergencial: concedida em caráter extraordinário, nos casos em que o estudante se veja em situação de extrema dificuldade financeira de ordem imprevista (MRE, 2010) 
Como se vê, o programa de bolsas do governo brasileiro ainda não corresponde às demandas do número de estudantes ingressantes, sendo, na verdade, um mecanismo burocrático de um marketing político que visa apresentar o espetáculo das relações internacionais, em destaque os acordos bilaterais BrasilÁfrica. No entendimento de Ribeiro (2007) a política externa brasileira não é somente reativa aos impulsos externos oriundos dos grandes centros hegemônicos, mas também resultado de esforços políticos domésticos, "hábeis em absorver e adaptar-se a esses impulsos, transformando-os em objetivos ou situações a resistir, combater ou negociar" (RIBEIRO, 2007, p.285).

Há desse modo, interesses domésticos e externos na busca da redefinição da inserção do Estado brasileiro no sistema internacional em que o continente africano se apresenta como "peça-chave" para essa estratégia do governo brasileiro. Portanto, as apresentações referentes ao avanço no oferecimento de vagas na educação superior para estudantes de países em desenvolvimento é um "prato cheio" para uma política externa brasileira de sucesso.

De acordo com Mungoi (2007) até a década de 1990 o governo brasileiro ainda concedia bolsas de estudo de um salário mínimo aos estudantes do PEC-G, no entanto, elas seriam um auxílio complementar ao dinheiro enviado pelas famílias. Porém com o passar do tempo, o governo decidiu cortar o beneficio. Segue-se agora uma política de competitividade entre os próprios estudantes do convênio em que aquele que obtém melhores notas ou melhor desempenho segue à frente na solicitação de bolsas.

Como lembra o estudante G.A., angolano, às vezes o estudante precisa de livros, vai à biblioteca e não tem o livro lá, então tem que comprar, né? Eu tenho uma bolsa, mas falha demais... quando paga, se você fizer uma economia, é bem rentável. Mas tem as coisas de uso pessoal, tem o lazer... Assim, até mesmo os estudantes que contam com uma bolsa de estudos, muitas vezes, passam por dificuldades financeiras que, consequentemente, comprometem outras necessidades financeiras, como aluguel, roupas, alimentação e lazer.

Observa-se que o PEC-G/PG busca cooperar com a continuidade dos estudos destes/as estudantes, sendo, portanto, um benefício coletivo e individual (DESIDÉRIO, 2005) de consolidação de vínculos sociais, acadêmicos e intercâmbio. Porém, é "também um programa que se limita a um determinado público seletivo que comprove solvência econômica para estudar no país e se manter sem custos 
adicionais para o Estado que o recebe e/ou que o envia". (DESIDÉRIO, 2005, p.124). Assim, é nítida a afirmação de que o Ministério da Educação, representado pelas Instituições de Ensino Superior, não tem qualquer responsabilidade financeira perante estes/as estudantes, portanto, o estudante assina um termo de compromisso e responsabilidade (anexo 2) afirmando ter recursos próprios para sua permanência com os respectivos comprovantes de renda.

Os responsáveis financeiros se comprometem a custear a permanência do estudante e as passagens de ida e volta. Como alerta Mungoi (2006) a coparticipação da família no PEC-G leva-nos a repensar/questionar a relação entre Estado e família, no sentido de que, "ao criar mecanismos para a participação da família no programa, definindo a obrigatoriedade do financiamento dos estudos pelos seus parentes, o Estado acaba intervindo no percurso, nos projetos e na esfera privada de milhares de africanos" (MUNGOI, 2006, p.34).

Entretanto, o fato de os/as estudantes assumirem a responsabilidade financeira diante do governo brasileiro nem sempre é algo concreto e viável. Assim como a autora, identificamos estudantes com difíceis condições de manutenção das despesas estudantis, de moradia e alimentação em universidades que não dispõem de bolsa para os/as mesmos/as, muito menos de estabelecimentos de apoio, como a Casa do Estudante e o Restaurante Universitário, ficando a cargo de funcionários, colegas e pessoas sensibilizadas com a dificuldade deles para arrecadarem alimentos, assegurarem a moradia e permitirem que estes/as estudantes continuem o curso.

Como já salientado, há casos extraordinários como a bolsa do MRE ou a chamada bolsa emergencial, além daquelas oferecidas pelas próprias instituições de ensino a partir de suas deliberações internas ou referentes àquelas ligadas a projetos de pesquisa como PIBIC (Programa Institucional de Bolsas de Iniciação Científica), PIBID (Programa Institucional de Bolsas de Iniciação à Docência), PIVIC (Programa Institucional de Voluntários de Iniciação Científica), PROLICEN (Programa Bolsas de Licenciatura), CAPES (Coordenação de Aperfeiçoamento de Pessoal de Nível Superior), CNPq (Conselho Nacional de Desenvolvimento Científico e Tecnológico), dentre outras. A assistência acadêmica culmina, assim, do cumprimento de horas-atividade em projetos de pesquisa, presença em laboratórios, bibliotecas etc., recebem moradia estudantil nas Casas do Estudante, mas isso não é uma regra, muito menos um acordo prévio, visto que, ao chegarem, ainda 
dependem da solidariedade de colegas estrangeiros para ocuparem quartos já ocupados, muitas vezes, lotados ou, posteriormente, dividirem apartamentos, kitinetes, de acordo com a condição financeira de cada um/a. Há também, pelo menos no programa das universidades, a assistência médica, psicológica e odontológica à disposição desses/as estudantes, desde que eles/as disponham de tempo e disposição para "buscarem" uma vaga.

Um importante marco para a permanência dos estudantes do convênio PEC trata-se do Projeto Milton Santos de Acesso ao Ensino Superior (PROMISAES) instituído em 2005, que tem beneficiado, principalmente, os/as estudantes de países africanos, oferecendo apoio financeiro referente a um salário mínimo mensal durante o curso, desde que demonstrem bom desempenho acadêmico, com tempo de duração de 01 (um) ano passível de renovação. São exigidas as seguintes condições para a participação no processo seletivo, segundo a Universidade Federal de Goiás, por exemplo:

a) estar inserido no Programa Estudante-Convênio de Graduação - PEC-G;

b) estar regularmente matriculado em curso de graduação da UFG;

c) já ter concluído o primeiro semestre de estudos;

d) não ter reprovação por falta no semestre anterior à seleção;

e) declaração socioeconômica expedida pelo Serviço Social da PROCOM/UFG atestando a condição de baixa renda. (www.prograd.ufg.br, 2013)

O benefício será suspenso se houver:

1. Conclusão do curso na IFES;

2. Desligamento do PEC-G;

3. Evasão da IFES por parte do beneficiário;

4. Reprovação por falta no semestre anterior à seleção e durante a vigência do auxílio;

5. Trancamento geral de matrícula, com exceção de casos de doença grave do beneficiário ou de familiares;

6. Falsidade de documento e/ou informação prestada pelo beneficiário, constatada em qualquer momento pelos coordenadores do Projeto e (ou) pelos órgãos de controle;

7. Substancial mudança de condição socioeconômica do beneficiário, que comprometa a observância das prioridades do PROMISAES e seus documentos de referência;

8. Pedido de desligamento do PROMISAES por parte do beneficiário;

9. Decisão judicial;

10. Falecimento do beneficiário; 
11. Se o estudante exercer qualquer atividade remunerada com recursos públicos (exceto as voltadas para fins curriculares e de iniciação científica) ou passar a receber outro auxílio financeiro do governo brasileiro;

12. Transferência para IES não atendida pelo PROMISAES;

13. Não atualização de prorrogação de visto anual junto a Polícia Federal. (www.prograd.ufg.br, 2013).

Assim, o programa apresenta exigências comuns ao pleiteamento de bolsas em geral, o que o diferencia é a exigência que comunga com o PEC-G e a particularidade do benefício a um estudante estrangeiro. Mesmo que seja um processo extremamente seletivo, consideramos que o PROMISAES é um incentivo importante aos ingressantes do PEC-G e os coloca numa maior possibilidade de aquisição de bolsas pelo fato de não corresponder a uma seleção de caráter universalista, ou seja, o PROMISAES é uma espécie de ação afirmativa a estes/as estudantes, apresentando-se como um diferencial positivo ao estudante-convênio, já que nos deparamos mais com a falta de divulgação do PEC-G nas universidades, com a negligência no atendimento aos/às ingressantes, na falta de orientação/recepção aos/às mesmos/as que culmina numa separação entre o estudante-convênio e o estudante intercambista.

Assim como o PEC-G, o Programa de Estudantes-Convênio de PósGraduação (PEC-PG) foi criado oficialmente em 1981 para oferecer formação em cursos de pós-graduação strictu sensu (mestrado e doutorado) em Instituições de Ensino Superior (IES) brasileiras por candidatos de países em desenvolvimento. Para estes estudantes são oferecidas vagas em cursos recomendados pela Capes sem custos de matrícula, bolsa mensal oferecida pela Capes ou CNPq e passagem aérea de retorno ao país. O Ministério das Relações Exteriores divulga o programa no exterior e se encarrega de pagar as passagens de retorno, enquanto o Ministério da Educação é responsável pela seleção e pagamento de bolsas.

De acordo com informações do Ministério das Relações Exteriores (2010) ao longo da última década, mais de 1.600 estudantes de pós-graduação foram selecionados pelo programa, sendo $75 \%$ destes provenientes da América do Sul, principalmente da Colômbia, Peru e Argentina. Os estudantes pós-graduandos de países africanos correspondem a aproximadamente $20 \%$, sendo, principalmente, de Moçambique, Cabo Verde e Angola, conforme quadro abaixo. 
Quadro 6 - Candidatos Africanos Selecionados de 2000 a 2012

\begin{tabular}{|l|c|c|c|c|c|c|c|c|c|c|c|c|c|c|}
\hline PAis/ANO & $\mathbf{2 0 0 0}$ & $\mathbf{2 0 0 1}$ & $\mathbf{2 0 0 2}$ & $\mathbf{2 0 0 3}$ & $\mathbf{2 0 0 4}$ & $\mathbf{2 0 0 5}$ & $\mathbf{2 0 0 6}$ & $\mathbf{2 0 0 7}$ & $\mathbf{2 0 0 8}$ & $\mathbf{2 0 0 9}$ & $\mathbf{2 0 1 0}$ & $\mathbf{2 0 1 1}$ & $\mathbf{2 0 1 2}$ & Total por pais \\
\hline Angola & 1 & 1 & 6 & 3 & 1 & 2 & 3 & 7 & 5 & 2 & 8 & 10 & 8 & 57 \\
\hline Benin & & & & & & & & & & 1 & & 1 & 2 & 4 \\
\hline Cabo Verde & 4 & 4 & 5 & 5 & 6 & 12 & 22 & 6 & 8 & 7 & 15 & 4 & 14 & 112 \\
\hline Cameroun & & & & & & & & & 2 & & & & 1 & 3 \\
\hline Costa do Marfim & & & 2 & 1 & 1 & 3 & 1 & 3 & & & & & 1 & 12 \\
\hline Egito & & & & & & & & & 1 & & & & & 1 \\
\hline Gana & & & & 1 & & & & & & & & & & 1 \\
\hline Guiné-Bissau & 1 & 1 & 3 & 1 & 1 & 6 & 5 & 2 & 3 & 2 & 6 & 2 & 5 & 38 \\
\hline Moçambique & 5 & 5 & 9 & 5 & 8 & 12 & 16 & 12 & 9 & 3 & 8 & 21 & 24 & 137 \\
\hline Namíbia & 1 & 1 & & & & & & & & & & & & 2 \\
\hline Nigéria & & & & 1 & & 1 & & & & & 1 & & 2 & 5 \\
\hline Rep. Dem. Congo & & & & & & & & 1 & & & & & & 1 \\
\hline S. Tomé e Príncipe & & 1 & & & & 4 & & & & 1 & 1 & 1 & 2 & 10 \\
\hline Senegal & 2 & 2 & & & & & 1 & 1 & & & & & & 6 \\
\hline Total por ano & $\mathbf{1 4}$ & $\mathbf{1 5}$ & $\mathbf{2 5}$ & $\mathbf{1 7}$ & $\mathbf{1 7}$ & $\mathbf{4 0}$ & $\mathbf{4 8}$ & $\mathbf{3 2}$ & $\mathbf{2 8}$ & $\mathbf{1 6}$ & 39 & 39 & $\mathbf{5 9}$ & 389 \\
\hline
\end{tabular}

Fonte: www.dce.mre.gov.br. Acessado em março de 2010.

Ainda se comparado ao número de estudantes de graduação, a pósgraduação corresponde a um desafio enfrentado por poucos. Pela exigência do retorno ao fim da graduação e a obrigatoriedade em possuir vínculo empregatício no país de origem, muitos estudantes desistem de continuar os estudos strictu sensu ou adiam para outra oportunidade. Apesar de reduzido o número de estudantes pósgraduandos/as africanos/as, o governo brasileiro incorporou inúmeros incentivos com o oferecimento de bolsas por meio da CAPES e CNPq iguais àquelas oferecidas para os/as estudantes brasileiros/as, o que facilita o custeio com moradia, alimentação, transporte etc., recebem a passagem de retorno ao país de origem. $O$ mapa 5 abaixo refere-se aos países africanos que oferecem o PEC-PG. 


\section{PAÍSES AFRICANOS PARTICIPANTES DO PEC-PG}

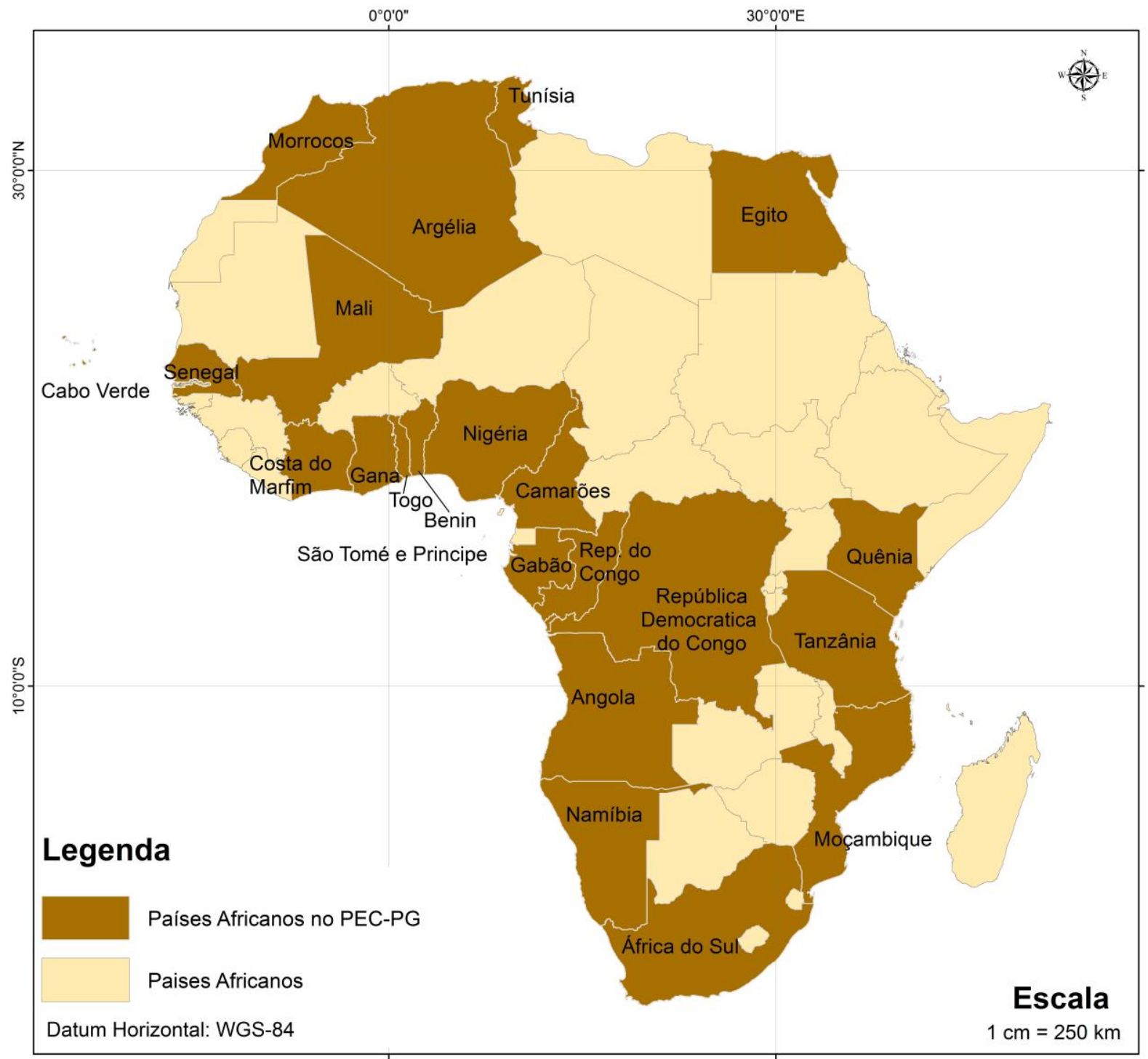

Fonte: Ministério das Relações Exteriores (2014).

Dos membros do PALOP, apenas Guiné Bissau não apresenta estudantes de pós-graduação, entretanto, o continente africano ainda apresenta um índice pequeno de pós-graduandos/as ao compararmos com países da América Latina. $\mathrm{Na}$ seleção para o mestrado ocorrida em 2012, constata-se a presença maciça de estudantes oriundos de países da América do Sul encaminhados para grandes universidades como a USP, enquanto que para a região Centro-Oeste houve apenas 02 (dois) estudantes. Na seleção para o doutorado ocorrida no mesmo ano, apenas 08 (oito) candidatos foram selecionados para a região Centro-Oeste, com destaque para a Universidade de Brasilia (UnB). 
Os critérios para seleção ao PEC-PG são:

Ser cidadão de país em desenvolvimento com o qual o Brasil mantenha Acordo ou Memorando de Entendimento na área de Cooperação Cultural, Educacional ou de Ciência e Tecnologia.

Não ser cidadão brasileiro, ainda que binacional, nem possuir genitor ou genitora brasileiro;

Não possuir visto permanente, visto diplomático, visto MERCOSUL ou visto que autorize o exercício de atividade remunerada no Brasil;

Ter curso de graduação ou mestrado completo em uma das áreas do conhecimento científico;

Ser aceito por Instituição de Ensino Superior brasileira (IES), pública ou privada, em curso de mestrado ou doutorado avaliado pela CAPES com conceito igual ou superior a 03 (três).

Ter Curriculum Vitae cadastrado e/ou atualizado na Plataforma Lattes do CNPq, em Língua Portuguesa.

Ser financeiramente responsável pela passagem de vinda para o Brasil, por sua manutenção até o recebimento da primeira mensalidade da bolsa PEC-PG e pela manutenção de qualquer membro da família que o acompanhe durante toda a estada no Brasil;

Ser portador do Certificado de Proficiência em Língua Portuguesa (CELPE-Bras), se oriundo de país não lusófono, ou ser aprovado em exame de proficiência em língua portuguesa da CAPES, se oriundo de país não lusófono onde não se aplica o CELPE-Bras.

Ter permanecido em seu país por, pelo menos, dois anos após ter obtido o diploma brasileiro, no caso de ex-estudante graduado pelo Programa de Estudantes-Convênio de Graduação - PEC-G. (Disponível em: www.dce.mre.gov.br, 2010)

Desse modo, muitos são os requisitos para o ingresso do pós-graduandoconvênio e, por já estar no mercado de trabalho no país de origem, o compromisso com o retorno é concreto, ele/a está convicto de seu "papel", da importância da complementação de sua formação, principalmente, porque ela demanda aumento de salário. Embora não seja parte do requisito de seleção ter vínculo empregatício no país de origem, é comum os pós-graduandos já serem professores de ensino básico 
ou superior e a pós-graduação representa a complementação salarial e de qualificação. Com relação ao financiamento oferecido pelo governo brasileiro, H.A.M., moçambicano, 27 anos, relata que

a grande desvantagem é que a bolsa não cobre os custos das pesquisas, pois sendo uma bolsa de intercâmbio, para mim, 0 lógico seria que o estudante pudesse realizar uma pesquisa em seu país de modo a contribuir com a compreensão ou resolução de algum aspecto específico. Tenho que recorrer a valores pessoas para que isso aconteça. E a vantagem é que posso estudar e manter o meu trabalho e ascender de categoria na minha carreira de docente. (H.A.M. estudante moçambicano de pós-graduação).

Esta preocupação de H.A.M. em pontuar as vantagens que a pós-graduação pode trazer para sua carreira profissional é recorrente a muitos estudantes pósgraduandos, senão o grande objetivo que impera as ações acadêmicas. Muito mais do que produzir conhecimento, o ensino superior, e com mais afinco a pósgraduação hodiernamente, representa a corrida para a qualificação baseada em padrões de excelência, de produtividade, de progresso científico e produção de conhecimento, quando, na verdade, acirra-se a busca por um padrão de qualidade baseado em critérios quantitativos e aplicáveis na competição da concorrência no emergente mercado de serviços universitários, como lembra Santos e Filho (2008).

\subsection{O Centro-Oeste e a corrida pela qualificação: o caso de três universidades goianas}

Nos últimos 20 anos, o Centro-Oeste constituiu-se como referência nacional de potencialidade agrícola, com crescimento notável. Sendo assim, a região constitui um dos macroespaços de maior potencial de desenvolvimento para a economia nacional, a segunda região em extensão territorial do Brasil. Essas assertivas nos apontam para um entendimento da estratégia de expansão do ensino superior em território nacional em que as diferenciações regionais e interesses socioeconômicos e políticos fundam instituições e as estabelecem como elemento de poder.

Como salienta Amorim (2010) o território nacional, ao aderir ao processo de modernização em que os ideais liberais atrelados à concepção de educação, culminou também com a expansão do ensino superior. O aumento dessa expansão se deu, em larga escala, com a fundação de instituições privadas de ensino. Tal expansão se orientou conforme a necessidade de locais previamente selecionados 
para receberem investimentos e infraestruturas para possibilitar o funcionamento destas instituições alocadas.

De acordo com Oliveira et. al. (2013) o cenário do ensino superior em Goiás mudou com a reforma educacional ocorrida no período de governo de Fernando Henrique Cardoso, entre 1995 e 2002. Dentre outros aspectos, essa reforma promoveu a flexibilização e diversificação de cursos, aumento no numero de instituições de ensino superior, principalmente com a expansão do setor privado. Varias instituições privadas foram criadas e em 1998 a faculdade isolada UNIANA mantida pelo poder publico estadual transforma-se na Universidade Estadual de Goiás no ano de 1999, assumindo uma disposição multicampi, com elevado número de alunos na graduação e oferta de cursos.

Até a primeira metade da década de 1990, o Estado de Goiás possuía três universidades: a Universidade Católica de Goiás (UCG), criada em 1959, hoje Pontifícia Universidade Católica (PUCGO), a Universidade Federal de Goiás (UFG), criada em 1960; e a Faculdade de Ciências Econômicas de Anápolis (FACEA), criada em 1961. Outras instituições atuavam basicamente na formação de técnicos e se resumiam ao ensino dos currículos de formação específica de cada área, alem de não incluir a pesquisa como parte do currículo.

O ensino superior em Goiás atualmente responde a um boom de universidades privadas, instituições de ensino superior que procuram manter critérios de excelência e qualidade do ensino numa tentativa de equiparação à Universidade Federal, mais visada pelos vestibulandos em geral.

Nos anos 1980 foram criadas autarquias estaduais, fundações municipais e instituições de ensino isoladas de cunho privado que caracterizaram os chamados "anos de euforia" (OLIVEIRA e LEMOS, 2009) no âmbito do ensino superior em Goiás, como um reflexo do processo de modernização e "desenvolvimento" regional. Numa perspectiva desenvolvimentista, a idéia é que IES instaladas tornam os municípios atrativos aos investimentos, amplia a oferta de serviços e de empregos e melhora as condições de vida da população local. "Trata-se, pois, da crença de que o ensino superior colabora diretamente com o desenvolvimento do município e da região do seu entorno" (OLIVEIRA e LEMOS, 2009, p.29).

Como salienta Catani e Oliveira (2002) o processo de expansão de vagas nas instituições federais de ensino superior obedece, de certo modo, o reconhecimento do Estado sobre a necessidade de manutenção de instituições públicas 
consideradas de alta qualidade, de âmbito nacional, que sirvam de referência às demais. Assim, algumas IFES são mantidas, consideravelmente, com recursos do poder público, tem o apoio das fundações de amparo à pesquisa que visam a investigação científica e o incentivo à pós-graduação. São estas universidades delegadas à produção do conhecimento científico em que o tripé ensino, pesquisa e extensão aparecem como um elo indissociável, pelo menos no projeto político pedagógico. Lembra Castro (2004) que a reforma do ensino superior atingiu as universidades federais de pequeno e médio portes, ainda jovens, nesse aspecto, em que a competitividade acadêmica, a busca por altos índices de produtividade e notas de excelência imposta pelos órgãos avaliadores do ensino superior são ainda metas a serem, constantemente, conquistadas.

A Universidade Federal de Goiás, a Pontifícia Universidade Católica e a Universidade Estadual de Goiás são instituições jovens, com aspectos organizacionais distintos e realidades opostas, mas todas elas procuram responder às exigências dos órgãos avaliadores da maneira que lhes é possível e têm se destacado como as principais universidades goianas.

Ao analisar dados do Instituto Nacional de Estudos e Pesquisas Educacionais (INEP), Castro (2004) afirma que apesar da maior concentração de matrículas no Sudeste, o crescimento mais expressivo de número de matriculas ocorreu nas regiões Norte e Centro-Oeste, com 21,9\% e 20,31\%, respectivamente, em decorrência do aumento do numero de cursos e vagas.

No que tange ao estabelecimento de instituições de ensino superior na cidade de Goiânia, capital do Estado de Goiás, a primeira universidade, Universidade Católica de Goiás - atual PUC-GO - foi fundada em 1959. Conta-se, em fontes históricas sobre o ensino superior em Goiás que houve intensas articulações políticas da Igreja Católica para o aceleramento da aprovação da fundação da universidade (OLIVEIRA et.al, 2013).

No ano de 1960 foi fundada a Universidade Federal de Goiás e em 1962 a Escola Superior de Educação Física e Fisioterapia do Estado de Goiás (ESEFFEGO), hoje um pólo da Universidade Estadual de Goiás. Na década de 1980, Goiás entrou num processo de expansão do ensino superior, mas isto ocorreu principalmente nas cidades do interior seguido da privatização de instituições de ensino superior públicas já existentes. De acordo com Dourado (2001) 
(...) o processo de redefinição política em Goiás, na década de 80 , acena com indicações de políticas educacionais que apontam para a expansão do ensino superior. Destaca-se, nesse período, a ênfase nos discursos de defesa do desenvolvimento regional e da necessidade de expansão, entendida, nesse contexto, através do estabelecimento da política de interiorização do ensino (Dourado, 2001, p. 64).

A política de interiorização do ensino superior consolidou-se com a criação de faculdades estaduais e de fundações municipais em cidades consideradas pólos econômicos. Com instituições moldadas como organizações empresariais, houve o aumento de investimentos lançados por empresários locais e de outros estados com a vinda de instituições privadas já consolidadas, como a Universidade Paulista (UNIP) e Universidade Salgado de Oliveira (UNIVERSO).

A expansão do ensino superior privado em Goiânia estabeleceu-se, segundo Oliveira e Lemos (2009) em três vertentes, sendo pela criação de novas IES no município, pela instalação de IES que já possuíam campi em outras cidades e pela criação de novos cursos e aumento de vagas nas IES privadas já existentes e nas IES criadas durante a década de 1990. Assim, numa visão "positiva" diante do aumento de IES no Estado de Goiás, o Estado tem sido considerado um pólo universitário da região Centro-Oeste e Goiânia, enquanto capital, tem atraído estudantes de várias partes do país e do mundo. Esse argumento tem servido de marketing político para as universidades goianas atraírem estudantes e se consolidarem como centros de excelência ou mostrarem que estão atentas ao processo de modernização do ensino e da produtividade acadêmica e científica.

A Universidade Federal de Goiás foi criada no dia 14 de dezembro de 1960 pela Lei oㅡ 3.834 C e reestruturada pelo Decreto o 63.817, de 16 de dezembro de 1968, com a reunião de cinco escolas superiores existentes em Goiânia: a Faculdade de Direito, a Faculdade de Farmácia e Odontologia, a Escola de Engenharia, o Conservatório de Música e a Faculdade de Medicina. A partir de então, como expressa um documento institucional dessa universidade (2010),

Goiás passou a formar seus próprios quadros profissionais e a não depender de mão-de-obra qualificada vinda de outras regiões do país. Para os estudantes goianos isso significou a oportunidade de formar-se profissional e intelectualmente em uma instituição pública, gratuita e de qualidade, e para o 
estado representou um marco na sua história (UFG, 2010, p.17).

Este discurso representa bem a necessidade de afirmar os interesses das elites locais desde a década de 1960, o fortalecimento da cidade de Goiânia enquanto uma jovem capital e os interesses do capital na implementação da qualificação da força-de-trabalho. Como salienta Amorim (2010) há um movimento conjunto da modernização do território com as novas formas de organização da produção, o que intensifica a demanda por maior escolarização dos brasileiros. Esse fator insiste na abertura de novas instituições educacionais no território, que visam o "esperado" desenvolvimento cientifico e tecnológico.

Para este fim, numa escala do poder estatal em Goiás e a nível de Brasil, políticas públicas foram elaboradas para o alargamento da interiorização do ensino superior e criou-se o financiamento de bolsas de estudo em instituições privadas. Estes dois modelos de política pública foram primordiais na construção de uma "cultura" acadêmica no Estado, no incentivo e aumento de cursos de graduação, possibilitando uma diversificação de estabelecimentos de ensino superior no Estado de Goiás.

No mapa 6 a seguir, tem-se o exemplo da consolidação e expansão da Universidade Estadual de Goiás, considerada um dos carros-chefes eleitorais da política e campanha do governador Marconi Perillo, já eleito em três mandatos (de 1999 a 2002, 2003 a 2006 e 2011 até os dias de hoje). 


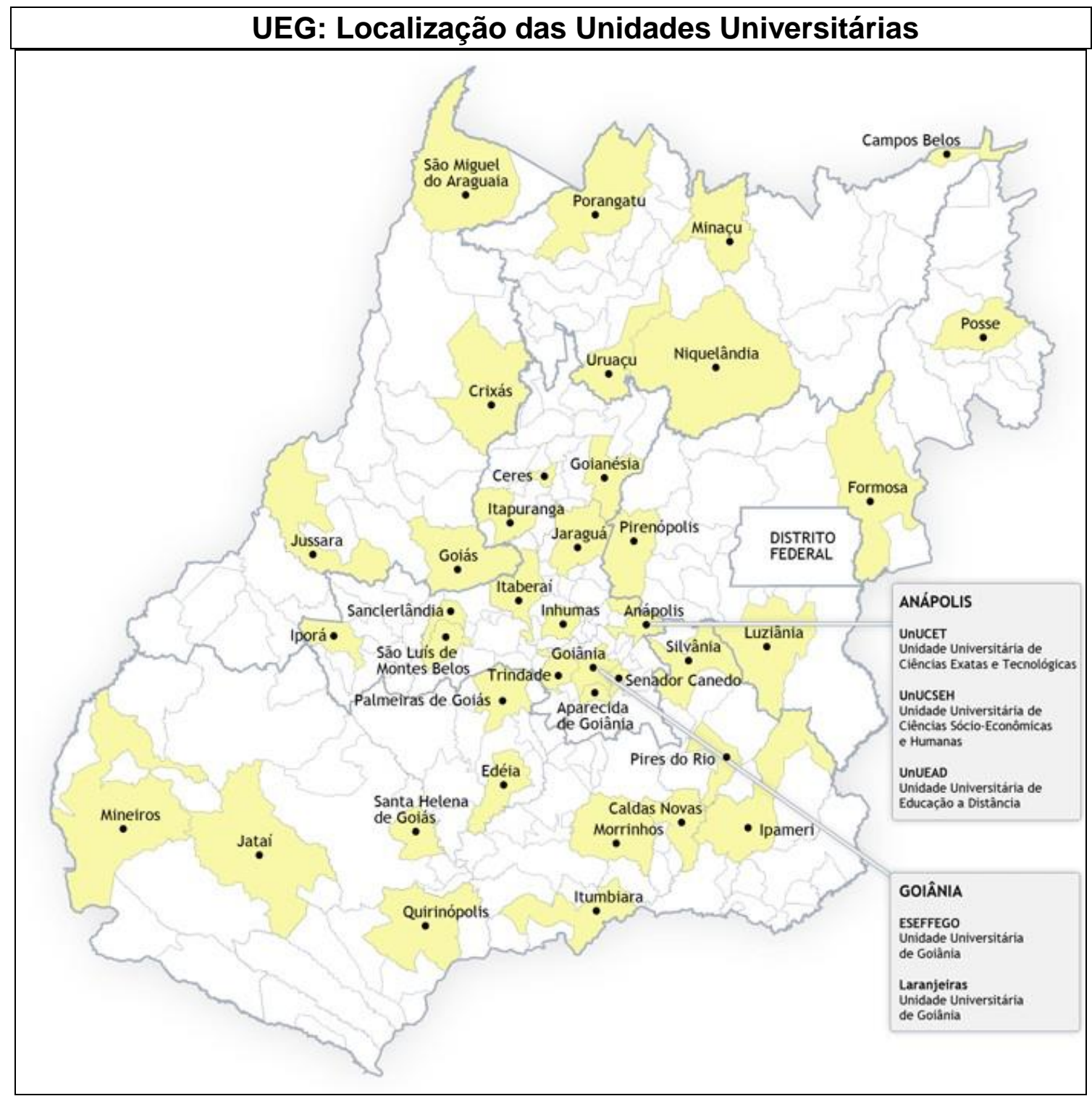

Fonte: UEG, Gerência do Núcleo de Inovação Tecnológica, 2013. Disponível Em http://www.cdn.ueg.br/arquivos/avaliacao_institucional2/conteudoN/1181/ueg_localizacao_das_unida des_universitarias.pdf

A consolidação da UEG tornou o poder estadual um significativo provedor de ensino superior no Estado de Goiás, confirmando a esta universidade uma dependência histórica ao governo do Estado. A expansão do ensino superior em Goiás ocorreu, segundo dados do INEP de 2006 (SILVA, I., 2008), acima da média nacional, sendo que o numero de matriculas em instituições públicas foi de $31,2 \%$ e a média nacional de 25,9\%. Este aumento deveu-se, principalmente, à política de interiorização do ensino superior através da UEG e a transformação das licenciaturas parceladas já existentes em licenciaturas plenas presenciais para atender à demanda dos corpos docentes dos municípios e do próprio Estado para permanecerem no mercado de trabalho ou ingressarem nele. 
Contraditoriamente a este discurso de benefício da criação da UEG para a sociedade goiana, vê-se os problemas enfrentados por uma universidade multicampi recente adequada a interesses políticos de campanhas governamentais. Segundo Silva e Reis (2011), os baixos salários dos docentes, a ausência de vínculo efetivo com a instituição, obriga-os a buscarem outros empregos, impedindo a permanência do docente na unidade universitária para oferecer ensino, pesquisa e extensão, limitando-se ao regime "aulista". O número de docentes graduados, segundo dados do INEP de 2012 (UEG, 2012) é de 13,7\%, de especialistas é de 47\%, mestres representam $29 \%$ e doutores apenas 10,7\%.

Além destes impasses, talvez um dos mais significativos na fragilidade da UEG enquanto universidade, a corrida pela internacionalização da mesma, o aumento de especializações, mestrados interinstitucionais, editais de fomento à pesquisa, são indícios de que há uma necessidade de adequação ao que se considera instituição de excelência e de qualidade. $O$ incentivo pelos programas de intercâmbio, a participação como receptora de estudantes do PEC-G são importantes elementos que fazem parte do chamado padrão de qualidade do ensino, no entanto, questões estruturais fundamentais para a recepção destes estudantes, como moradia, alimentação e demais condições de permanência não são problematizadas e providenciadas. A situação precária em que estudantes africanos/as têm vivido enquanto estudantes da UEG reforça o despreparo da instituição como possível mantenedora de programas de intercâmbio em termos administrativos a urgência em rever administrativamente seus reais interesses e sua realidade. 


\section{CAPÍTULO III}

\section{O SUJEITO SUJEITADO DA MIGRAÇÃO ESTUDANTIL NA MOBILIZAÇÃO PARA A QUALIFICAÇÃO DA FORÇA DE TRABALHO: O/A ESTUDANTE AFRICANO/A, PERCEPÇÕES DE IDENTIDADE, RAÇA E (COM)VIVÊNCIA COM O RACISMO OU COMPREENSÕ̃ES DA CONDIÇÃO DE ESTRANGEIROS/AS E NEGROS/AS}

\subsection{Migrante e identidade: a provisoriedade e o pertencimento na mobilidade}

Não é uma tarefa fácil ter de compreender o outro a partir de nosso olhar. Por vezes é um terreno teórico pantanoso e improvável. No entanto, esse é o caminhar da investigação que nos acomete de dúvidas permanentes e questões mais agigantadas que as respostas.

Desde que adentramos o pensar a migração sob o viés da temporariedade, unindo espaço e tempo como matrizes do pensamento geográfico, temos pensado na necessidade de justificar um objeto que é o/a migrante estudante. A pesquisa anda ou pára dependendo do movimento desses migrantes, ela só existe por e a partir deles e esta constatação, por vezes, nos aflige, pois percebemos quão frágil se torna uma investigação que propõe-se a analisar, em certa medida, a vida deles.

Com as reflexões da crítica do valor-dissociação, da qualificação da força de trabalho, da identidade negra, migrante e estudante, temos compreendido que estes sujeitos sujeitados estão inseridos num cotidiano em que não se percebem ou se sentem como objetos ou fantoches nas mãos das exigências de qualificação e do desenvolvimento, seja eles de onde vierem, mas que se posicionam como sujeitos com suas individualidades, suas coletividades, no esconde-esconde da vida urbana e universitária. E assim a pesquisa depende do tempo e do espaço do/a migrante em questão, pois é isso. Por certo, não se pode deixar de mencionar o que Sayad (1998) já demonstrava na sua inquietude teórica e empírica diante do/a migrante no sentido de inferir que

não se pode escrever inocentemente sobre a imigração e sobre os imigrantes; não se pode escrever sem se perguntar o que significa escrever sobre esse objeto, ou, o que é o mesmo, sem interrogar-se acerca do estatuto social e científico desse mesmo objeto (SAYAD, 1998, p. 21).

Assim, escrever sobre o/a migrante estudante exige também desvendar sua não existência no olhar teórico, na sua particularidade temporária e na constatação 
do caráter da temporariedade como um elemento que constitui tal particularidade. Ou seja, o/a estudante é migrante à medida em que desloca-se no espaço e traz consigo sua individualidade, sua identidade, as lembranças e planos traçados, ao mesmo tempo em que interpreta o estudo como um ato presente para a viabilização de sua qualificação educacional/acadêmica. Ele/a não está em seu país de origem e representa, muitas vezes, a promessa de uma carreira promissora que visa garantir o bem-estar e sua ascensão social e familiar.

Se seguirmos o raciocínio de Sayad (1998), entenderemos que o estudo do/a migrante deve levar em consideração a sua provisoriedade. Portanto, ele/a só é migrante por ter a provisoriedade como um elemento intrínseco à sua condição. Desse modo, precisam se convencer de que vivem a partir dela. Não importa quanto tempo fiquem no país receptor, serão sempre "convidados/as" ao retorno por suas famílias, futuros trabalhos e oportunidades. Nesse sentido, compreender que o/a estudante faz parte da engrenagem que movimenta a sociedade moderna é entende-lo/a também a partir da migração. É possível considerar o/a migrante a partir de dois olhares, assim como salienta Silva, M., (2005),

(...) inicialmente, trata-se de um(a) trabalhador(a) produzido(a) no bojo de determinadas relações sociais, as quais muitas vezes, resultam de processos de violência e expropriação(...) Em seguida, o migrante insere-se em uma realidade social, definida por laços sociais (familiares, grupos de vizinhança, valores, ideologias etc), que o caracterizam como pertencente a um determinado espaço social e cultural (SILVA, M., 2005, p.54).

A partir do entendimento da dissociação-valor, compreendemos o/a migrante como integrante de um processo social que incute diferentes variáveis que fazem parte do universo do/ migrante, seja como individuo ou como grupo social em que se apresenta como sujeito sujeitado às consequências do sistema moderno produtor de mercadorias.

Migrar para qualificar a sua força de trabalho é a perspectiva fundante ou mais evidente do/a estudante migrante, evidenciando os fatores econômicos na analise da migração e dos/as migrantes. Pensamos que o/a estudante é, futura e atualmente, um/a trabalhador/a em potencial, a migração pelo viés do trabalho é um aspecto constitutivo para poder compreender a sua realidade social e seus laços sociais. 
As referências sobre o/a estudante migrante pouco são evidenciadas como uma problemática teórica e até um questionamento ao nomearmos como migrante o/a estudante que possui visto temporário. Gomes (2002) utiliza o termo migração estudantil e preocupa-se com o relato da trajetória escolar do/a estudante angolano/a no Brasil. Evidencia que a proposta de análise é compreender e relatar as experiências vividas pelos/as estudantes, na maneira como lidam com a condição de estrangeiros/as, podendo assim trazer à tona as condições de vida na universidade, no local em que residem, as redes estabelecidas com outros/as e com brasileiros/as. Ainda como preocupação, o autor espera que seu trabalho sirva de um alerta ou denúncia sobre a maneira como as universidades têm acompanhado ou não - esses/as estudantes.

Nesse sentido, embora seja uma preocupação de Gomes (2002) ressaltar os motivos dos fluxos desses migrantes, percebe-se que ele ainda se pauta, de maneira que os nomeia como "reais atores de suas ações", numa abordagem nãohistórico-estrutural da migração. Na mesma linha de interpretação sobre a migração estudantil, observamos os trabalhos de Ngoumane (2010), Alves (2008), Fonseca D. (2009), Magalhães (2008) entre outros, que buscam reconstituir a identidade e os conflitos do migrante temporário na condição de estudante.

Ngoumane (2010) recorre aos conceitos de etnia, raça, nacionalidade, rede de sociabilidade e parentesco para uma melhor compreensão da presença de estudantes moçambicanos no Brasil. Alves M. (2008) enfatiza os acordos bilaterais e as relações políticas como portas de entrada para o fluxo de estudantes africanos no país e, assim, analisar e compreender a reconstrução identitária da comunidade cabo-verdiana no Rio de Janeiro. Fonseca D. (2009) reforça o entendimento do imaginário do jovem estudante migrante, o qual ele denomina estudante intercambista angolano, calcado em conflitos diante do estigma do migrante temporário e o estereótipo do refugiado de guerra, o sonho de voltar para o país de origem e as atratividades encontradas no Brasil. Magalhães (2008) retrata as narrativas de estudantes angolanos percorrendo o caminho da memória e da oralidade. Faria (2009) propõe discutir a importância da mobilidade para os estudos superiores, em termos das expectativas à partida, das possibilidades de escolha, assim como do modo como esta situação contribui para a reconfiguração da posição social, sobretudo para aqueles que têm como expectativa o regresso ao país de origem. 
Todos estes trabalhos referem-se a pontos ricos de compreensão da migração do estudante na atualidade, inserindo-se em diversas perspectivas para a investigação e, em nenhum momento, questiona-se a inserção da categoria migrante para o grupo social em questão. O estudante vive uma particularidade do processo migratório no sentido de que sua vinda está condicionada a programas de cooperação cultural e educacional bilateral firmados entre os governos brasileiro e de seus respectivos países (MUNGOI, 2007), no entanto, insere-se em suas relações sociais nas leituras de mundo que o/a migrante faz, lendo fatos vividos sob o olhar do estranhamento, da comunidade, da amizade, reservando momentos de descontração e conversa com os/as conterrâneos/as e demais estudantes africanos/as advindos/as de outros países.

O visto temporário em que se insere a categoria de estudante impede qualquer possibilidade de trabalho remunerado durante a estadia no país receptor, o que pode ser um entrave para a inserção mais evidente do/a estudante na sociedade brasileira economicamente ativa. Do ponto de vista da intenção dos acordos, trata-se de esperar que este/a estudante, munido/a do diploma de Ensino Superior, possa exercer a profissão escolhida em seu país de origem ou continuando, muitas vezes, um cargo que já ocupava posteriormente.

Muitas situações foram apresentadas pelos/as estudantes entrevistados/as acerca de algumas barreiras com que se deparam ao longo dos anos de estudo, no entanto, o que se pôde perceber é que o fato de não poderem trabalhar constitui-se como um percalço de grande dimensão, visto que uma atividade remunerada, para eles, poderia complementar a renda enviada pelos pais ou proveniente de alguma bolsa de estudos.

Pensamos que a questão do trabalho é de suma importância para contribuir com a reflexão acerca da migração temporária e culmina em outras investigações e olhares quando se refere a estudantes. Como já vimos, a perspectiva históricoestrutural de compreensão da migração foca o trabalho como elemento principal, em detrimento das vontades pessoais e projetos individuais. Trata-se de compreender, mais uma vez, que a migração estudantil não pressupõe a priori decisões individuais e familiares se é perceptível os acordos, os projetos políticos de desenvolvimento que movem esses/as jovens e alimenta um ciclo de gerações de imigrantes e "retornados". 
No pêndulo entre temporariedade e permanência para discutir a migração estudantil, lembramos no questionamento feito por Goettert (2009) quando apresenta a dúvida se uma semana é o suficiente para definir uma migração, ou quando se inicia ou termina uma migração. É justamente para suplantar ou driblar essa discussão que este autor trabalha com 0 conceito de transitoriedade/transitividade migratória, abarcando desde a decisão de migrar até a convicção de não se pertencer ao lugar em que chegou. É fato que a visão teórica do autor nos remete a um entendimento puramente subjetivo do/a migrante em que a própria percepção deste sujeito anteriormente ao próprio deslocamento, interfere na sua condição de ser/estar em trânsito ou de finalizar este trânsito. É como se compreendêssemos que se ver enquanto migrante ou sentir-se como tal é um processo social lento, que obedece gradações, fases, impressões e ações que, aos poucos, tornam-se concretas.

As expectativas dos migrantes permeiam 0 universo da transitoriedade. Todos/as os/as estudantes entrevistados/as demonstraram o abismo existente entre a representação e imaginário acerca do "local de acolhida", as expectativas ao desembarcarem em outro país e a concretização de uma outra realidade enquanto morador/a estrangeiro/a. O processo de transitoriedade não é algo dado a priori por elementos como a distância espacial ou tempo cronológico entre partida e chegada,

(...) pelo contrário, a dimensão subjetiva - sim, de cada migrante - assume a centralidade sem, evidentemente, deixar de "dialogar" com outras dimensões da vida, como a material e a política. Des-acostumado, des-ajeitado e des-locado (no extremo, "trans-lo(u)cado") são características dessa condição trans-migratória. E relativamente comum ouvir de migrantes que "ainda não me acostumei aqui" ou "já estou acostumado neste lugar", ou "prefiro lá" ou "não gosto daqui". Semelhantemente, quem migra transita por jeitos diferentes de serlestar, que podem ser verificação mais atenta de "transitório" (GOETTERT, 2009, p.58).

O que se procura constatar aqui é o jogo semântico entre o conceito de transitório e transitivo, no sentido de evidenciar que aquilo que é passageiro, efêmero comunga com aquilo que se transforma, que transita. Portanto,

a condição de transitividade migratória é de ligação e não de separação, por mais paradoxal que possa parecer: 0 
"transitório" parece não pressupor a passagem de um estado a outro ou de uma condição a outra (na migração, de um lugar para outro) porque "passa", é "passageiro" e "efêmero"; na perspectiva da transitividade migratória, o que se pressupõe não é apenas a passagem de um estado a outro ou de uma condição à outra (ou, na migração, de um lugar para outro), mas no amálgama entre dois ou mais estados ou entre duas ou mais condições, no (des)encontro entre dois ou mais lugares: 0 migrante é e não é, está e não está, é presente e ausente, é ausente e presente, simultaneamente (GOETTERT, 2009, p.58).

Também, a partir da ótica da transitoriedade migratória, é possível lembrar que a ideia de retorno também presente muitas vezes na expectativa do migrante, corresponde a uma linha tênue, pois, embora não seja aqui a intenção de pensar as concepções acerca do retorno, ele apresenta-se como um mito, visto que a própria condição social do/a migrante vincula-se à memória de suas vivências no país de origem e ao retorno.

A migração não é uma escolha do migrante, mas uma necessidade arquitetada, imposta pelas relações sociais, como já frisaram Sayad (2000) e Gaudemar (1977) e o retorno também acaba por se constituir como mito, no sentido de que nada, nem lugares, nem hábitos, nem vivências são estáticas e permanecem como um quadro à espera da volta daquele que se foi. Assim, Ocada (2003, p.24) diz que "não se pode encontrar na mesma situação, as pessoas e os lugares que foram deixados pra trás". O deslocamento decorrente da migração representa, por certo, uma ruptura com o passado.

O retorno propriamente dito merece uma atenção aprofundada, pois constitui um elemento intrínseco ao estudo da migração, no entanto, nossa investigação não galga horizontes tão amplos a ponto de trazer a questão do retorno dos/as estudantes aos seus países, nem a inserção dos/as mesmos/as no mercado de trabalho, visto que demandaria um acompanhamento com riqueza de detalhes e acompanhamento da rotina profissional e familiar no país de origem.

Para Sayad (2000) o retorno representa uma das dimensões essenciais da antropologia das migrações na medida em que pressupõe relações com o tempo, o tempo de ontem e o tempo do futuro, a representação de um e a projeção do outro, sendo dependentes do tempo presente e uma relação com a terra na sua dimensão física e social. Essas dimensões pressupõem uma necessária compreensão das relações sociais do migrante em retorno numa sociedade regida pelo valor e a cisão. 
$\mathrm{Na}$ condição de estudantes, o retorno é um elemento inquestionável, pois de antemão existe este pressuposto como parte das normas que regem o visto temporário de estudante. Estudar e retornar são, portanto, parte do acordo estabelecido no convênio, há uma preocupação com o retorno como se fosse uma dívida estabelecida com o Programa Convênio de Estudantes (PEC).

Outro fator percebido nas entrevistas, é que há, por parte de alguns/mas, uma lamentação pelo que ficou pra trás no sentido de deixar emprego e perspectivas de melhoria da qualidade de vida e ter que recomeçar, como representa o comentário de E.S., 22 anos, angolana: "eu tenho de traçar o futuro de acordo com a realidade agora. Cheguei aqui e tudo mudou, está tudo parado em Angola [para a situação dela], eu tinha emprego e agora não sei como vai ser quando eu voltar". A incerteza do que os espera na volta assola o pensamento de muitos/as estudantes, no entanto, a realização de uma graduação em outro país se configura como um importante elemento favorável na (re)inserção na economia de mercado.

O retorno é também parte do projeto familiar dos/as mesmos/as, uma vez que o fato de muitos pais financiarem os estudos em termos de possibilitar a permanência - moradia e alimentação - e o acesso a livros, equipamentos e viagens evidencia a necessidade de fortalecerem a ideologia do discurso do retorno, afirmando que o projeto de vida é a formação e o retorno, como evidencia A., 23 anos, caboverdiana, "estudar para ajudar o país".

A relação de provisoriedade e retorno traçam o perfil do/a estudante migrante no sentido de que ela é reconhecida e percebida por aqueles que o/a vêem na universidade, nas ruas ou nas casas de estudantes. A presença estrangeira como pontuou Sayad (2000) é pensada necessariamente como provisória mesmo quando há uma indefinição quanto ao tempo, o que nos leva a entender que a presença estrangeira pode ser durável, mas de qualquer forma, provisória.

Ao mesmo tempo em que se pode falar da efemeridade no que Goettert (2000) chama de transitividade migratória, também remete-se a uma condição permanente de ver/sentir-se como migrante, mesmo que este estado se finde, mesmo que o retorno aconteça, já que esse sentimento e condição depende do/a migrante e suas formas de lidar com a mudança, com o provisório e com o permanente, com as distâncias têmporo-espaciais em que elementos estruturais como o político, o econômico e o social se interpenetram diante da condição de sujeito sujeitado. 
A migração de estudantes tem caráter temporário, na medida em que existe um cronograma de permanência e retorno que, teoricamente, deve ser cumprido. No entanto, ao longo do tempo de estadia, não é incomum ouvir histórias de alguns/mas estudantes que resolveram permanecer, seja por meio da união civil com brasileiras, no caso de homens, ou exercendo algum trabalho. Podemos alegar as considerações de Martins (1988) ao tratar da condição do migrante temporário também na análise dos/as migrantes estudantes quando salienta que a migração temporária é um modo de desatar os laços de família, ao mesmo tempo em que se configura como um modo de atar o desenvolvimento do capital. Ser migrante temporário é, assim,

(...)ser duas pessoas ao mesmo tempo, cada uma constituída por específicas relações sociais, historicamente definidas; é viver como presente e sonhar como ausente. É ser e não ser ao mesmo tempo; sair quando está chegando, voltar quando está indo. É necessitar quando está saciado. É estar em dois lugares diferentes ao mesmo tempo e não estar em nenhum. É, até mesmo, partir sempre e não chegar nunca (MARTINS, 1988, p.45).

Desse modo, não podemos considerar a migração apenas do ponto de vista do deslocamento espacial, visto que o sentido e a condição de transitoriedade do migrante de uma sociedade a outra é um elemento forte na sua relação com um "novo" mundo. O/a migrante desloca-se entre particularidades espaciais de uma sociedade do valor-cisão. Complementa Fonseca (2010) que o/ migrante participa de uma cultura que fornece como referência normas de comportamento apoiadas num sistema de valores culturais que, aos poucos, fazem parte de sua identidade.

Ainda fortalecendo as reflexões de Martins (1988) sobre o/a migrante temporário/a, é inegável que, nas andanças, nos encontros com nossos migrantes em questão, a dubiedade do ir e voltar, o sair e o retornar é bastante presente nas histórias de vida de cada um. O que cabe lembrarmos é a viagem sem volta que o/a migrante faz, no sentido de que se há um retorno,

(...) já não é o mesmo; e, por ter que sair, nas condições em que sai, modifica as relações sociais do seu grupo de origem, altera a organização da família, a divisão do trabalho familiar, o lugar de cada um. O que encontra, quando retorna, já não é aquilo que deixou. Ele nem mesmo se reencontra porque já é outro, procurando ser o mesmo. (MARTINS, 1988, p.45). 
Esta passagem é tocante à medida que o cenário da vida do/a migrante temporário/a vai se construindo, seja no campo do simbólico ou da materialidade, em incertezas. Em nenhum momento, os/as estudantes que entrevistamos mencionaram a temporariedade como um fator marcante, no entanto, nas entrelinhas do encontro, no relato sobre a cambaleante situação de estrangeiro/a demonstravam a inconformação, talvez a indignação diante da condição de "outro", ao mesmo tempo em que muitos se esforçavam para participarem de atividades cotidianas a estudantes brasileiros e vivenciar/consumir a cidade de Goiânia como um/a goianiense. O discurso positivo acerca do retorno é forte e contundente, assim, parece-nos que a dor do distanciamento físico não é o foco, não é o problema, é apenas uma parte de um processo muito maior e mais importante.

Outro aspecto relevante para este estudo atém-se à discussão referente à identidade e pertencimento racial. Os grupos sociais em movimento/deslocamento vivenciam o território a partir das redes de "solidamizade" (um misto de solidariedade e amizade), dos locais em que se estabelecem, na convivência com o "outro", nas ações cotidianas como o ir e vir à universidade, o encontro com os/as colegas nas casas de estudantes, nas festas organizadas por e para eles/as, nos passeios a parques e shoppings, fóruns virtuais, comunidades e curtidas no facebook e nos jogos de futebol.

É perceptível que existe o que Safran (apud CLEMENTE, 2005) chama de forte solidariedade interna, produtora de identidade e de vida social, portanto, enquanto não retornam, desenvolvem comunidades que se apresentam na forma de guetos fechados ou de redes abertas a pessoas "de fora" do grupo. Daí que, muitas vezes, ouvimos os/as brasileiros/as se referirem aos/às estudantes africanos/as como fechados/as, pouco sociáveis e/ou comunicativos. Mas comungamos da afirmação de Clemente (2005) ao dizer que aqueles/as em situação de mobilidade fazem alianças de rede e, podemos afirmar que não se trata de manter relações apenas com os/as conterrâneos/as ou africanos/as na condição de estudante, pois há sim amizade com brasileiros/as, seja em relacionamentos afetivos, em grupos de estudos ou convivência diária nas universidades ou casas de estudantes.

Nossa intenção permeia os caminhos do (re)conhecimento racial como um elemento que constitui-se como uma particularidade do/a estudante africano/a e temos acompanhado pelas bibliografias existentes a importância da raça, da identidade e sua relação com a migração. Mesmo que possa parecer pertinente 
esse aspecto apenas do ponto de vista antropológico e/ou sociológico, o olhar geográfico busca compreender a raça como resultado eficaz da dominação colonial moderna capitalista, podendo ser vista em sua relação com território e pertencimento, em estudos sobre segregação urbana, territorialidades, em suma, na sua relação com o espaço.

\subsection{Identidade étnico-racial e migração: vivências do/a migrante estudante nas universidades goianas}

A raça enquanto um elemento social artificial e crucial na estruturação de sistemas de hierarquia e exploração (QUIJANO, 2007) foi capaz de estabelecer, ao longo do sistema moderno do mundo ocidental, a dominação de territórios, acordos políticos, o fortalecimento de potências econômicas e, o que abarca o campo simbólico, a supervalorização de matrizes culturais e étnicorraciais em detrimento de outras. Assim, o racismo, como um desdobramento comportamental da crença nas diferenças raciais, também se constituiu como um mecanismo ideológico de dominação econômica fetichizada.

Moore (2007) nos chama a atenção pelo fato de a sociedade ocidental trivializar e subestimar a ideologia do racismo. Ele apregoa a causa à necessidade da classe dominante de manter o status quo e consolidar sua posição como segmento racial dominante. Assim, a banalização do racismo visa

(...) criar a impressão de que "tudo anda bem" na sociedade, imprimindo um caráter banal às distorções socioeconômicas entre as populações de diferentes "raças". Os que acreditam no contrário podem ser julgados "revoltosos", "inconformados" e, até mesmo, "racistas às avessas". [Portanto], a expansão e aceitação do racismo conduzem, inexoravelmente, à sua banalização (MOORE, 2007, p.29).

Podemos afirmar que a banalização do racismo refere-se a uma construção histórica e processual, portanto, conivente, muitas vezes, com posicionamentos críticos acerca das relações sociais, econômicas e culturais que regem o sistema moderno. Da mesma forma, a existência e impregnação do racismo nas relações cotidianas atesta a gravidade de uma história baseada na opressão e dominação. $O$ que é crucial é entendermos que a dimensão racial tem seu peso no processo 
histórico de dominação capitalista e nas mediações sociais que regem o sistema moderno produtor de mercadorias.

$\mathrm{Na}$ medida em que apresenta-se uma ligação e discussão acerca dos aspectos da migração internacional e suas nuances, o debate étnico-racial ganha força e consistência, visto que os conflitos étnico-raciais se fazem presentes na questão migratória, embora muitas vezes não sejam considerados temas fundamentais ou pertinentes da/para a pauta.

Para discutirmos o racismo e sua ligação com a migração, faz-se mister falarmos sobre a construção da identidade, como este conceito permeia o discurso nos estudos sobre estrangeiros, migrantes e, em nosso caso, negros/as estrangeiros/as. A identidade racial é um fator de conflito/aproximação com o "outro" e, no caso dos/as estudantes africanos/as, acaba aparecendo como um importante mecanismo de diferenciação e reconhecimento enquanto grupo social.

A identidade, se tomarmos como referência os estudos de Hall (2011), ao longo do tempo pressupôs o indivíduo numa concepção iluminista e numa ideia de sujeito/subjetividade, o sujeito sociológico numa concepção interativa do eu com a sociedade ou, ainda o sujeito pós-moderno baseado na fragmentação e na variabilidade. Este, nos tempos atuais, estaria submetido ao constante deslocamento, mutabilidade histórica e cultural, portanto, portador de múltiplas identidades e não de uma "plenamente unificada, completa, segura e coerente" (HALL, 2011, p.13). Nesse sentido, a identidade pode ser um elemento mutável e, muitas vezes, politizado, já que institui marcadores da diferença como cruciais na construção de um pertencimento identitário.

Hall (2011) procura atentar-se para as transições entre as diferentes concepções de sujeito no que ele chama de modernidade e modernidade tardia (segunda metade do século XX). Ele visa problematizar as inferências de que, a partir de então, as identidades encontram-se fragmentadas para pontuar que, na verdade, elas se deslocam. Esse processo ocorre a partir da descentralização ou descentração do sujeito no modelo iluminista de sociedade, primeiramente, com o pensamento marxista - em que as relações sociais deslocaram a noção abstrata de "homem" individual - depois com o pensamento freudiano - em que desloca o sujeito racional de identidade fixa e única para um sujeito que é produto do inconsciente -, com o pensamento saussuriano - que afirmava que o indivíduo não é autor dos significados expressos na língua, pois ela é um sistema social - e, por fim, pelo 
pensamento foucaultiano - quando faz uma genealogia do sujeito moderno a partir do poder disciplinar que, de certa forma, individualiza mais o sujeito através das instituições de controle do corpo. Por outro lado, a pluralidade de identidades encontra sua chave na identidade da da forma social e da totalidade concreta (SCHOLZ, 2009).

Dessa forma, aparece a necessidade de uma crítica do modelo iluminista de sujeito moderno no momento da crise fundamental do processo de modernização. Segundo Hall (2011) constrói-se identidades abertas, flexíveis, contraditórias, inacabadas, características próprias ao período chamado de pós-moderno. Assim, há um entendimento de que

(...) quanto mais a vida social se torna mediada pelo mercado global de estilos, lugares e imagens pelas viagens internacionais, pelas imagens da mídia e pelos sistemas de comunicação globalmente interligados, mais as identidades se tornam desvinculadas - desalojadas- de tempos, lugares, histórias e tradições específicos e parecem "flutuar livremente" (HALL, 2011, p.75).

Essa concepção de fluidez da identidade está bastante presente nas leituras contemporâneas de cunho pós-colonialistas e ajudam a entender de que maneira o falar sobre identidade requer uma abordagem plural e complexa, pois um indivíduo ou um grupo social se constrói a partir de vínculos variados, alguns mais intensos que outros, aprendidos e apreendidos. Como lembra Appiah (1997) as identidades são complexas e múltiplas e surgem a partir de respostas às forças econômicas, políticas e culturais, quase sempre em oposição a outras identidades e não há muita razão na construção das mesmas.

Essa multiplicidade das identidades deve ser entendida como particularidade e coloca-se a tarefa de entender a totalidade concreta nessas particularidades enquanto essência. Para Castells (2008) toda e qualquer identidade é construída socialmente e marcada por relações de poder. Considerando a identidade destinada à resistência percebemos que o grupo social formado pelos/as estudantes africanos/as assim se (re)faz no que se refere ao estabelecimento de vínculos capazes de reforçar o coletivo. Não é incomum depararmos com estes/as estudantes no dia-dia, fazendo outras atividades além da ida para a universidade em grupo, principalmente, quando se trata de pessoas do mesmo país. 
A identidade étnico-racial é uma problemática que se apresenta de maneira explícita quando abordamos estudantes estrangeiros/as na universidade apresentando-se como um dos principais locus de vivência dos/as mesmos/as. Claro que vivenciar a cidade, participar de outros espaços além do universitário é algo presente em seus cotidianos, mas diríamos que a universidade representa o mais importante espaço de reconhecimento como/do "outro", representa os momentos mais concisos de enfrentamento da diferença, da percepção de si mesmo/a enquanto "outro".

As conversas informais, as entrevistas foram significativamente feitas na universidade e na casa do estudante onde muitos/as residem ou se encontram diariamente que acaba se configurando como uma extensão da universidade, pois todos ali obedecem à rotina dos estudos, da frequência nos restaurantes universitários, na convivência com colegas do mesmo curso ou de cursos diferentes, utilizam o mesmo transporte coletivo e usufruem até mesmo de momentos de lazer na própria universidade.

Um importante exemplo disso é a organização anual de um evento organizado por estes estudantes intitulado Semana da África, realizada no mês de maio, em que os/as estudantes se encontram, debatem, pensam em temáticas relacionadas ao continente africano a serem apresentadas por palestrantes diversos, dentre professores, pesquisadores, embaixadores etc, apresentação dos próprios alunos sobre seus países e questionamentos que envolvem principalmente problemas e preocupações com seus países ou com a visão homogeneizada e homogeneizante sobre o continente africano. Todos os anos em que participamos deste evento, a observação mais contundente que fica é o expressivo esvaziamento e a não presença do público estudantil brasileiro nos debates, no entanto, durante as oficinas de tranças - momento em que as estudantes africanas confeccionam tranças nas pessoas presentes composto por mulheres - a presença de estudantes brasileiras é significativa.

O que se percebe então é que torna-se muito mais atrativo participar de algo que remete à África com sua criatividade estética e técnicas de "embelezamento" do que discussões acerca das questões que envolvem as relações econômicas e políticas com o Brasil. Em alguns momentos específicos a Universidade Federal, por iniciativa da reitoria e do próprio PEC (Programa de Convênio de Estudantes), realizaram mesas redondas e encontros na tentativa de situar o estudante 
estrangeiro no que tange ao papel da universidade, aos programas, cursos e projetos que ela oferece a todos os estudantes, mas não foi possível encontrar material de divulgação sobre estes momentos, mesmo entrando em contato com a Coordenadoria de Assuntos Internacionais. Posteriormente, foi-nos informado que tudo o que se refere ao PEC fica a cargo da Pró-Reitoria de Graduação, havendo, desse modo, pouca ligação e cooperação entre os dois departamentos da universidade.

O único material encontrado que remete ao estudante estrangeiro e sua experiência segundo a Coordenadoria de Assuntos Internacionais da UFG são relatos de alguns estudantes, visando divulgar a importância desta universidade na sua realização profissional e no contato com a diversidade cultural, expressão bastante valorizada no discurso da mesma, enfatizando o "contato humano" munido de solidariedade que supera qualquer dificuldade ou estranhamento, como a seguir:

“Em princípio a minha motivação para estudar no Brasil foi estudar num país em via de desenvolvimento, onde a formação profissional vai além do seu caráter técnico, mas científico, ético e humano, e a sua diversidade cultural, que motiva qualquer acadêmico no mundo. A UFG foi onde obtive os melhores docentes e melhor assistência estudantil que me possibilitou concluir a graduação. Os docentes dessa instituição são espelhos de sucesso dos seus graduados que estão atuando em diferentes cantos do país e outros países (África). O que chamou atenção na UFG, em resumo, foi a solidariedade dos colegas, docentes e servidores técnicos dessa universidade e a vontade do povo brasileiro para atingir suas metas. Com essa cultura aprendi ser mais objetivo e criativo para alcançar o desejado. Ao chegar aqui tive algumas dificuldades, mas acredito [que] qualquer pessoa no mundo ao chegar numa cultura diferente passa dificuldade de adaptação. A dificuldade foi um pouco da língua, apesar de ser de origem de um país de língua portuguesa passei bastante tempo para me situar dentro da universidade e também dificuldade de adaptar com a comida. A outros estudantes que desejam estudar nesta Universidade, eu diria que venham, porque a UFG possui estrutura física adequada e ótimos docentes que the possibilitam atingir seu objetivo. Goiânia também é uma das cidades menos violentas, baixo custo de vida e possui assistência estudantil necessária”.(C.A.T., de Guiné-Bissau, estudante de Medicina da UFG) Fonte: www.cai.ufg.br, 2013.

Em geral, tem-se na fala acima uma representação contundente da intenção em destacar a universidade como centro de excelência de ensino e qualidade nos 
mais variados aspectos. Em primeiro plano vem o reforço da parceria Brasil e outros países, neste caso, africanos, que tem visado formar quadros profissionais competitivos, mas com o diferencial de preocupar-se com a formação humana baseada em princípios éticos.

Em segundo plano vem a constatação de que a universidade em questão é solidária, oferece boa assistência ao estudante estrangeiro, têm qualidade em termos de corpo docente e infraestrutura, sem contar que, no entendimento do estudante, com o povo brasileiro se aprende a ser pragmático e a adaptar-se com criatividade aos percalços encontrados em país estrangeiro.

Em último plano vem o relato sobre as principais dificuldades encontradas, principalmente, no que se refere à língua, o que significa que, mesmo para um estudante de um país de língua portuguesa, ainda aparecem os problemas de compreensão e interpretação na convivência diária em sala de aula. Para terminar, o estudante faz um chamado aos demais, lembrando o sucesso de sua estadia e experiência vivida no Brasil e na UFG ao escolher Goiânia para morar e estudar. Lembramos que a escolha pela cidade de acolhida não se faz automaticamente de acordo com o interesse de cada estudante, mas sim a partir de um critério de oferta e demanda feito pelo PEC-G.

O que se vê, a partir da fala de muitos dos/as entrevistados/as, é que a vinda para Goiânia coincide com as boas expectativas dos/as estudantes, já que se vende nos meios de comunicação uma concepção de cidade planejada, ambientalmente correta, sem altos índices de violência e que guarda um ar interiorano e bucólico nas propagandas, na internet e, passada a decepção por não ser destinado à cidade que gostariam, muitos acabam reforçando essa concepção de "Goiânia como paraíso para se viver".

Uma estudante de Cabo Verde conta a experiência como intercambista na UFG:

Conheci a UFG através de uma seleção de alunos, que meus professores fizeram na minha universidade em Cabo Verde. Gostei muito do fato de ter vivido na universidade. Ter morado no campus - eu não fazia ideia do que era, ter morado numa casa só com estudantes, dividir quarto com estranhos, ter que conviver com mais de 100 pessoas diferentes, cada um com seus defeitos e qualidades para mim foi tudo muito novo, mas muito bom para meu enriquecimento intelectual e cultural. Eu incentivo os que querem vir estudar aqui. Encorajo os que querem vir, sabendo que a UFG dispõe de todas as 
condições para uma boa formação dos seus estudantes. Saio daqui com uma boa impressão da instituição e vou transmití-la para os meus colegas. (R.L.N., estudante de Cabo Verde na UFG) Fonte: www.cai.ufg.br, 2013)

A intenção maior do relato, assim como no anterior, é reforçar a importância da UFG no cenário acadêmico goiano, demonstrar que trata-se de uma universidade de destaque regional e que necessariamente outras pessoas serão indicadas para estudarem lá, no entanto, foi inevitável relatar o estranhamento da convivência na Casa do Estudante. Esta, por sua vez, muitas vezes é a única opção de estudantes de baixa renda ou vindos de cidades do interior e de outros estados. Foi estruturada para receber estudantes de baixa renda e soma hoje 464 vagas num total de 4 casas. Apenas uma está vinculada à Pontifícia Universidade Católica de Goiás.

De acordo com a Pró-Reitoria de Assuntos da Comunidade Universitária da UFG os requisitos básicos para o/a estudante pleitear uma vaga nas casas é ser de baixa renda, regularmente matriculado/a nos cursos de graduação e/ou pósgraduação strictu sensu, embora a prioridade seja para graduandos/as, ser procedente de cidades do interior de Goiás e/ou de outros Estados sem condições de arcar com as despesas de moradia.

Automaticamente, ao chegarem em Goiânia, os/as estudantes africanos/as são encaminhados para as casas do estudante, ficando próximos a outros africanos/as veteranos e, ali, vão construindo amizade e proximidade até se familiarizarem e, em alguns casos, formarem uma comunidade/grupo em casas ou apartamentos de aluguel. Em alguns casos, as redes estabelecidas no próprio país permite uma aproximação prévia com outros/as estudantes, muitas vezes já eram conhecidos em seus países e acabam por retomar a amizade, trocando informações sobre os estudos, a cidade, a moradia etc. Em Goiás, isso não é muito comum, pois ainda é incipiente o número de estudantes africanos/as nas universidades se comparado ao eixo Rio de Janeiro-São Paulo-Minas Gerais.

Segundo informações da PUC- Goiás, os estudantes do programa PEC-G ao chegarem em Goiânia devem buscar um local para residir, mas, primeiramente, são enviados para a Casa de Estudantes provisoriamente. Alguns optam por participar da seleção realizada pela Coordenação de Assuntos Estudantis que seleciona os mais "necessitados" para morar na Casa de Estudantes. 
Já a UEG, nos campi de Anápolis e Caldas Novas onde há estudantes africanos/as, não possui nenhuma casa estudantil e não oferece abrigo provisório aos que chegam, desse modo, os/as estudantes se valem de contatos com outros/as estudantes estrangeiros e/ou brasileiros para encontrarem um local para moradia de aluguel.

Consequentemente, a situação financeira deles deve assegurar a permanência na universidade, o que nem sempre acontece e alguns passam/aram por dificuldades financeiras, sem renda para moradia, alimentação e transporte. A universidade não se pronunciou sobre 0 caso, mas, segundo funcionários administrativos, já foram feitas até mesmo arrecadações por eles a fim de ajudar e assistir estes/as alunos/as.

Muitas vezes a alternativa dada a esses estudantes é a convivência conjunta e diária, principalmente para facilitar a administração dos gastos com moradia e alimentação. Se as casas estudantis estão cheias e não asseguram o direito de eles usufruírem desse benefício, cabe então enfrentar o aluguel, o que verifica-se outro empecilho, pois numa cidade como Goiânia e Anápolis, a capital e um dos principais pólos industriais do estado de Goiás, a especulação imobiliária e o custo de vida torna-se oneroso.

Para providenciar casas e apartamentos de aluguel, o inquilino deve apresentar um avalista residente na cidade há alguns anos, além de ter um imóvel em seu nome e renda compatível com o preço estipulado para o aluguel. Se esse critério é o recorrente nas empresas imobiliárias nestas cidades, é praticamente impossível um/a estudante africano/a, sem renda fixa, sem conhecidos/as na cidade, alugar algum imóvel por esta via. Restam outros caminhos baseados no interesse de alguns donos habituados a alugar imóveis para estudantes sem tais exigências.

Mesmo que falemos desses estudantes no sentido de comunidade e grupo social, que tornam-se amigos/as, alugam casas juntos/as para dividirem despesas, vão às mesmas festas ou organizem suas próprias festas, se ajudam na faculdade, estamos falando de um grupo extremamente heterogêneo, de diversos contextos nacionais e étnicos.

De acordo com Baungarten (2004) o grupo conforma uma coletividade que se refere à "organização social em um território sócio-organizacional delimitado sobre a base de laços ou sentimentos individuais e relaciona-se a grupos integrados por 
sentimentos comuns e por normas que regem a conduta dos mesmos" (BAUNGARTEN, 2004, p.04).

Se falamos de imigrantes, temporários ou não, na condição de estudantes não nos referimos a uma comunidade de iguais, mas sim, como afirma Gusmão (2006), coletividades nascidas em África, mas de nacionalidades e etnias diferentes que se interagem e se interrelacionam e, também, geram conflitos. Assim, encontram-se voltados para a construção da vida pessoal e coletiva, "mediante uma complexa rede de operações, decisões e negociações que ordenam representações sociais, alimentadas por um ser de lá (África) estar aqui (Brasil)" (GUSMÃO, 2006, p.51).

As representações sociais são construídas a partir de relações de poder, incluindo assim, informações, experiências, conhecimentos e modelos que permeiam a sociedade. Pavarino (2003), a partir de uma análise de Moscovici, salienta que a representação não se refere a algo estático e os indivíduos não são meros receptores passivos, mas sim participantes da elaboração de um pensamento social. As representações possuem o poder de alimentar as práticas culturais em vigor na sociedade, podendo reproduzi-las ou transformá-las. Embora sociais e historicamente localizáveis, as representações individuais e coletivas podem guardar um sentido geral que ultrapassa a sociedade que as viu nascer (SOUZA, 2008).

A discussão sobre as representações sociais nos ajuda em nosso entendimento sobre o/a migrante, sobre a maneira como a sociedade em geral enxerga-o/a e constrói papéis, fisionomias e comportamentos referentes a ele. De acordo com Gusmão (2006) o/a migrante se enxerga a partir do olhar da sociedade que o acolhe e não há diferenças entre o/a migrante trabalhador/a e o/a migrante estudante no sentido de que ambos são tidos como estrangeiros na terra do outro.

No Brasil ela acredita que há um desconhecimento acerca da identidade do/a estrangeiro/a que chega, pouca informação a respeito de suas pretensões e destinos, tornando-se praticamente invisível e há ainda um agravante quando se trata de estrangeiros pobres e negros.

Segundo dados da Polícia Federal de 2012, obtidos por um site de apoio a imigrantes refugiados e estudantes denominado "O estrangeiro", o Brasil abriga cerca de 940 mil imigrantes permanentes só no estado de São Paulo, como se vê no mapa 7. Os principais países de origem da população imigrante no Brasil são 
Portugal, com um número absoluto de 277.727, seguido do Japão, com 91.042 e Itália, com 73.126.

Ainda constata-se que o país tem sido alvo de migrantes brancos principalmente no que concerne ao número maior de oportunidades no comércio, na qualidade de vida, menores custos com moradia, alimentação e facilidade, em termos financeiros, em administrar estabelecimentos comerciais. Mesmo sendo menor o número de africanos/as no Brasil, quando nos remetemos aos estudantes estrangeiros/as vindos/as pelo PEC-G há uma considerável incidência deles/as nas universidades brasileiras.

\section{NÚMERO DE MIGRANTES ESTRANGEIROS POR ESTADO}

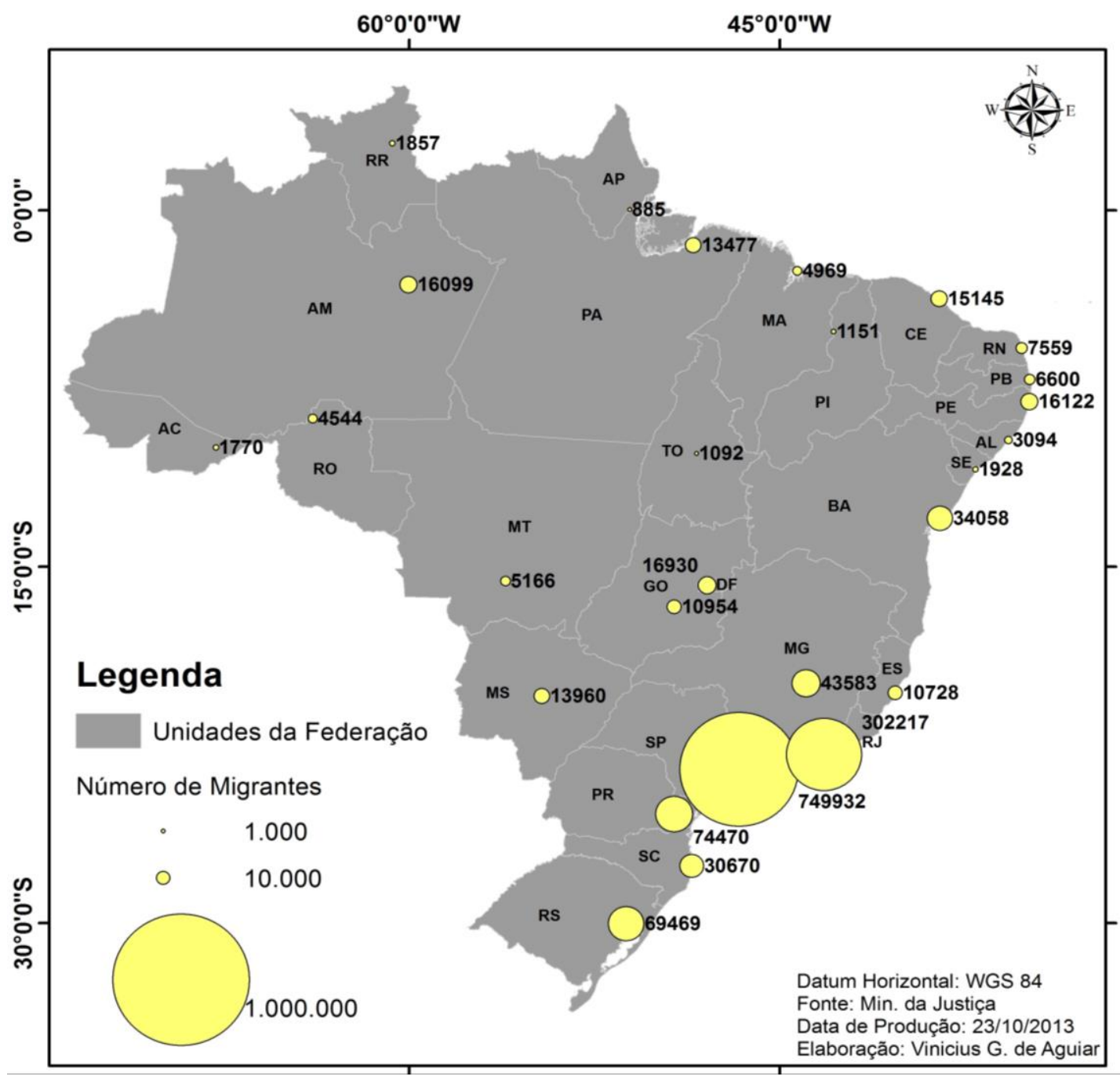

Fonte: Estrangeiros no Brasil. Disponível em: <http://www.oestrangeiro.org.br> em ago./2013 
De acordo com dados do Ministério da Justiça de 2011, o maior número de migrantes africanos/as no Brasil são provenientes de Angola, sendo um total de 4.230, seguido da Nigéria com 1.856 e de Cabo Verde com 1.005 pessoas. A região Sudeste é o destino de grande parte dos/as estrangeiros/as, com 749.932 em São Paulo, 302.217 no Rio de Janeiro, 43.583 em Minas Gerais e 10.728 no Espírito Santo. Em termos de estudantes migrantes, dentre as universidades brasileiras que mais recebem estrangeiros, a Universidade de São Paulo lidera o ranking, com 981 estudantes em 2011, 1.200 em 2012 e no primeiro semestre de 2013 um total de 705.

A título de comparação, a USP segue uma política de "acolhimento" dos/as estudantes estrangeiros através de medidas próprias tomadas por cada departamento, seja com palestras ou reuniões de recepção que visem informações administrativas e acadêmicas. Além disso há o programa chamado USP iFriends, criado em 2011 pela Vice Reitoria Executiva de Relações Internacionais (VRERI) em que os alunos da universidade recepcionam e ajudam os intercambistas, o que não é uma regra para os estudantes provenientes do PEC-G.

É perceptível que há uma diferenciação de tratamento, no que tange à recepção e obtenção de informações, entre os estudantes intercambistas e os provenientes do programa PEC-G. Embora a participação no PEC-G signifique um tipo específico de intercâmbio, observa-se uma separação feita pelas próprias universidades ao tratar de atividades culturais, assistência e informações a ambos os públicos. O intercâmbio apresenta-se como uma oportunidade de crescimento e preparo acadêmico destinado a estudantes brasileiros/as no exterior, bem como no privilégio das universidades goianas em receber alunos/as provenientes da Europa e dos EUA.

$\mathrm{Na}$ UFG são realizadas atividades especificas aos estudantes europeus e estadunidenses, inclusive em incentivar alunos/as brasileiros/as a recepcioná-los, levar para casa, mostrar opções de lazer na cidade etc. Todos os anos são ofertados cursos de língua portuguesa, viagem à cidade de Pirenópolis - cidade turística do centro-goiano-, sessão de filmes internacionais na casa do estudante, monitoria de línguas - quando o/a estrangeiro/a se ocupa em oferecer aulas de seu idioma oficial, jantar internacional e festas temáticas francesa, alemã, espanhola, portuguesa e estadunidense. 
Na PUC-Goiás não foi evidenciada nenhum tipo de atividade "cultural" de recepção a estrangeiros/as. Porém, assim que chegam são recebidos pela Assessoria de Assuntos Internacionais e pelo próprio reitor. Especificamente, com relação ao migrante, a universidade mantém o Grupo de Apoio ao Universitário Migrante (GUM) de responsabilidade da Pró-Reitoria de Extensão, Coordenadoria de Assuntos Estudantis e Paróquia Universitária São João Evangelista em que oferecem apoio aos acadêmicos provenientes de outros municípios, estados e países.

A UEG apresenta em seus objetivos, no que tange às relações internacionais, a disposição em auxiliar o/a estudante estrangeiro/a na busca por informações a respeito de alimentação, hospedagem, lazer, hospitais e na execução dos trâmites burocráticos referentes ao seu curso, ao funcionamento da universidade, sua estadia na cidade, validação de documentos em órgãos públicos.

De acordo com a Coordenadoria Geral das Relações Institucionais e Internacionais, a universidade oferece no site informações para o estudante do PEC$G$ a respeito do programa, de seu funcionamento e edital de seleção do ano correspondente. De antemão, já se apresenta as principais condições impostas ao estudante-convênio como provar que é capaz de custear suas despesas no Brasil, ter certificado de conclusão do ensino médio ou curso equivalente e proficiência em língua portuguesa, no caso dos alunos de nações fora da Comunidade de Países de Língua Portuguesa (CPLP).

O que não parece ser um problema para a amistosidade da UEG na recepção dos/as alunos/as estrangeiros/as é a ausência de uma Casa do Estudante que torna-se um empecilho para muitos/as que, após um certo tempo, não têm condições financeiras suficientes para hospedagem e alimentação.

Vê-se que a UEG ainda está em vias de construção enquanto universidade, por sua administração atrelada aos interesses do governo, ainda não oferece boas condições de trabalho para docentes e técnicos administrativos, a infraestrutura precária, excessiva quantidade de pólos e unidades que descentralizam ações efetivas de melhoria do ensino, pesquisa e extensão e, dentre outros aspectos, incipiente política de assistência estudantil.

Para os/as estudantes africanos do PEC-G a casa do estudante passa a ser a primeira opção de moradia, mesmo ocupando-a sem passar pelos trâmites da Assistência Estudantil, primeiramente vão ocupando quartos com camas vagas, 
depois se aproximando de outros estudantes estrangeiros, africanos mais precisamente, e muitos acabam se unindo para alugarem apartamentos em outros bairros da cidade próximos à universidade. Fica expresso nos informes que as universidades não garantem moradia aos que chegam, chegando a ser o primeiro aviso antes das demais providências e dúvidas sanadas.

Assim, nasceu uma preocupação/questionamento quanto à tarefa, talvez expressa em função ou papel, das assessorias nas universidades em questão, visto que grande parte do material divulgado nos sites oficiais e nas próprias sedes referese a oportunidades de intercâmbio para países europeus e América do Norte, principalmente, palestras de profissionais estrangeiros em visita ao país e à própria universidade, editais de vagas para intercâmbio em universidades conveniadas e informações sobre procedimentos burocráticos e documentais para intercâmbio.

Pouco se fala sobre o estudante-convênio PEC-G ou a importância dos mesmos para as universidades receptoras. Como se vê nos trechos abaixo há um incisivo discurso pautado no maravilhoso mundo do intercâmbio e seus benefícios para as universidades, além de ser um ponto a mais na corrida para o mercado de trabalho:

[...] Estudar fora é uma oportunidade de conhecer novas culturas e entrar em contato com realidades diferentes. É uma experiência única de aprendizado, onde o estudante/professor viaja com o desafio de aprender uma nova língua, encontrar pessoas de diversos países do mundo e aprimorar seus conhecimentos. O conhecimento adquirido em outro país é algo que se leva para toda a vida. As aulas em outra língua, os passeios com os colegas de sala e as amizades são lembranças que marcam o estudante/professor de intercâmbio. O intercâmbio, além do aprendizado, oferece oportunidades para quem aceita o desafio. Ao entrar no mercado de trabalho, falar uma língua a mais e ter uma experiência fora do país pode fazer a diferença. As empresas procuram jovens dinâmicos, com novas idéias e que não tem medo de arriscar (www.ueg.br, 2013).

[...] A política de ações internacionais visa promover o crescimento qualitativo do ensino, propiciar a busca e incorporação de novas tecnologias através da pesquisa, além de possibilitar condições à comunidade universitária de conviver e conhecer a diversidade cultural que propicia ao profissional uma formação cosmopolita consonante com 0 momento atual de evolução global (www.ufg.br, 2013). 
[...] A internacionalização é um caminho necessário para o aprimoramento do Ensino, Pesquisa e Extensão em uma universidade. $O$ intercâmbio cultural e acadêmico é extremamente importante para o fomento de novas idéias e busca de novas tecnologias. Uma universidade que busca se colocar no topo de qualquer ranking educacional ou profissional esbarrará, inevitavelmente, na internacionalização (www.pucgoias.edu.br, 2013).

Podemos observar a força de uma intenção mercantil e competitiva das universidades goianas e a corrida para se destacarem no cenário acadêmico nacional, utilizando, para isso, as possibilidades de intercambio como trunfo e, principalmente, a recepção de estrangeiros/as, europeus e norte-americanos principalmente, como prova de que a universidade tem qualidade em ensino, pesquisa e extensão e é atrativa.

Os/as estudantes africanos/as do PEC-G são vistos/identificados como estrangeiros/as negros/as, portanto, sua condição étnicorracial prevalece como um marcador de diferença. Se considerarmos os apontamentos de Brah (2006) sobre a diferença como uma categoria analítica, veremos que há várias maneiras de conceituá-la se pautarmos em uma escala macro ou micro, nos discursos e práticas imbuídos nas relações sociais.

De acordo com Brah (2006) a diferença pode ser conceituada como experiência, como relação social, como subjetividade e/ou como identidade. Embora ela utilize esses conceitos para discutir particularmente o feminismo, é possível fazer uma analogia com o que chamamos de diferença do/no migrante estudante negro/a quando relata que a experiência é um processo de significação da chamada realidade, é através dela que se forma o sujeito. Portanto, experiência e diferença estão longe de serem termos do senso comum. A experiência pode ser o locus da contestação, em caso das lutas políticas, não é uma categoria unificada fixa e preexistente, mas sim marcada pela multiplicidade das práticas culturais e políticas cotidianas.

A diferença como relação social pressupõe as trajetórias históricas e contemporâneas das práticas culturais que constroem a identidade de grupo. Segundo a autora, "questões de identidade estão intimamente ligadas a questões de experiência, subjetividade e relações sociais" (BRAH, 2006, p.371). As identidades são marcadas pela multiplicidade de posições que constroem o sujeito, portanto, a 
condição de migrante estudante africano repercute como identidade de um grupo, mas este mesmo/a estudante traz em si particularidades que o diferenciam de qualquer consideração homogeneizante.

A diferença enquanto identidade pressupõe que esta se inscreve a partir de experiências culturalmente construídas em relações sociais. É preciso lembrar que "as identidades coletivas não são redutíveis à soma das experiências individuais. Identidade coletiva é o processo de significação pelo qual experiências comuns em torno de eixos específicos de diferenciação são investidas de significados particulares" (BRAH, 2006, p.371).

Quando nos referimos a um grupo munido de um sentido de comunidade, de certa forma, nos remetemos a indivíduos que comungam de percepções, comportamentos, práticas culturais semelhantes e isso é visível ao nos depararmos com o grupo de estudantes africanos/as em questão, mas, ao mesmo tempo, grita a individualidade/particularidade de cada um a partir de sua trajetória.

Duas identidades que rondam o cotidiano dos/as estudantes, seja na universidade, seja em casa ou nas ruas referem-se ao "ser" estrangeiro e ao "ser" negro. Quando questionado sobre o que é ser negro/a estrangeiro/a no Brasil ou se é possível verificar que estes dois aspectos se fundem ou se fragmentam, o estudante J.M.L. de Guiné-Bissau diz "Quero sempre ser visto como negro estrangeiro, mas aqui [no Brasil] eu sou visto primeiro como negro. Isso só muda quando eu abro a boca".

A estudante D.M.M. de Cabo Verde relata que as pessoas a reconhecem enquanto estrangeira apenas quando ela fala, assim como o estudante V. F. L. de Angola que diz "na sala de aula, os meus colegas chamam-me sempre de angolano". Essa questão demonstra a maneira como o estudante africano/a é estigmatizado/a e rotulado/a, há uma série de situações relatadas pelos estudantes no que se refere à maneira como os/as colegas brasileiros/as expressam suas impressões e visões sobre o que é ser estrangeiro/a africano/a negro/a, evidenciando o preconceito e as representações sociais pejorativas sobre os países africanos envolvidos no PEC-G e PG.

(...)Alguns acham que a gente vem pra cá ocupar o lugar do brasileiro que devia estudar. Muitas vezes os brasileiros comentam "nossa, esse estrangeiro, ainda é africano e tem uma qualidade de vida melhor do que eu que sou brasileiro... 
eu entendo, é um pouquinho normal, quando eu estava em meu país, sem ainda pensar na minha condição de estrangeira, eu olhava para os estrangeiros de uma maneira diferente, que eles eram cheios de dinheiro, esse dinheiro vem de Angola, um monte de coisa, mas na verdade não é isso que acontece, eu acredito que as pessoas por desconhecerem, por ignorância acabam nos julgando dessa maneira.(...) (E.S., angolana, 22 anos)

(...)Eu sou muito bem tratada por brasileiros, tenho amigos brasileiros, mas há situações que nos aborrecem, muitas vezes o estrangeiro é visto como infiltrado, como uma pessoa que simplesmente veio e sei lá... como um estranho, nem sempre ele é bem vindo. Ser estrangeiro é difícil, acho que se vc estivesse no meu lugar vc saberia o que estou sentindo nesse momento (E.S., angolana, 22 anos).

(...)Ser vista como estrangeira ou negra depende do local. Na universidade eu sou estrangeira, mas no shopping, por exemplo, primeiramente sou vista como negra (A., caboverdiana, 23 anos).

(...)Não me sinto como negro no Brasil, mas como um estrangeiro diante da burocracia principalmente. Acho que a pele não é um diferencial (J., caboverdiano, 32 anos).

(...)Percebo que sou negro em sala de aula, ate porque sou o único negro (risos) e percebo que sou estrangeiro em instituições públicas até porque sou muito bem tratado. E também em algumas lojas e supermercados, sempre fui super bem tratado, com direito a fotos (risos) (F.M.B, angolano, 23 anos)

(...)Sou negro e estrangeiro na situação racial, lingüística, na alimentação e vestuário (J.D.A., guineense, 21 anos)

(...)As pessoas percebem que somos estrangeiros na forma de vestir e conversar (A.Q.A., guineense, 25 anos)

(...) Acredito que só sinto que sou estrangeiro quando me expresso e quando digo que sou, pois de forma contrária, pensam que sou brasileiro (H.A.M., moçambicano, 27 anos).

O que se nota, a partir dos relatos, é a maneira como o/a estrangeiro/a é representado/a também como ameaça, como um individuo que "tira" a oportunidade de "nativos", no caso dos/as estudantes, ocupam vagas que deveriam ser destinadas a brasileiros/as e daí para a intolerância é um passo. O/a estudante africano/a percebe-se então numa situação em que deve sempre ser cordial, 
amistoso/a com os colegas brasileiros para garantir sua aceitabilidade, enquanto se depara com situações discriminatórias e expressões racistas, seja no âmbito da vida universitária, seja na vida dentro das casas dos estudantes, nas instituições públicas, nos hospitais, nos bancos e nos momentos de lazer.

Contraditoriamente a este fato da percepção do racismo e da intolerância por parte de alguns/mas estudantes, há aqueles que não percebem ou não se sentem atingidos pelo racismo, afirmando até mesmo a existência de uma "vantagem" por serem estrangeiros/as. Como bem expressa F.M.B, estudante angolano, sempre foi muito bem tratado, quase como um artista, uma espécie de encantamento dos/as brasileiros/as pela sua condição de estrangeiro/a dizendo "eu notei que o negro angolano tem mais moral aqui do que o negro brasileiro e outros africanos negros. Eu digo que deve ser pelo português que a gente fala, normalmente as pessoas ficam encantadas. Eu sempre fui super bem tratado não tenho do que reclamar".

Além disso, como expresso na citação acima deste mesmo estudante, afirma que é bem tratado em todos os espaços públicos que frequenta. Este estudante, de certa forma, faz uma consideração bem específica da sua experiência pessoal de uma maneira otimista, mas ao mesmo tempo, não é indiferente às situações que ele observa a respeito da relação de seu grupo social com os/as brasileiros/as e se conforta lembrando que o período no Brasil vai acabar, que voltará para sua terra natal e lá se estabelecerá como um bom profissional.

Ele afirma que "no Brasil os negros são considerados como pobres, gatunos, burros e feios (risos), eu falo para os meus amigos que ainda bem que não sou brasileiro, daqui a pouco formo e volto para o meu país onde a maioria é de lá mesmo". O fato de acreditar no retorno e saber que ele vai acontecer alivia a tensão quando se pensa na situação do negro no Brasil, como se pensar nisso ou no próprio racismo fosse algo temporário assim como sua condição de migrante que, uma vez cessada, volta-se a enxergar a vida como angolano em seu próprio país e com seu objetivo cumprido.

O estudante H.A.M, com seu relato, nos traz uma importante observação a respeito das similaridades do Brasil com Cabo Verde no que tange à composição racial de suas populações. Ao afirmar que no Brasil ele só se sente estrangeiro quando as pessoas perguntam a partir de seu sotaque, pois pelo fato de ter 0 fenótipo negro de pele clara, quase se passa por brasileiro. 
A construção de uma identidade nacional em Cabo Verde culminou com complexas relações entre "africanidades" e "europeidades", no sentido de se oporem, uma vez que, por muito tempo, houve um grupo intelectual disposto a construir a identidade caboverdiana pautada na sua proximidade com Portugal, sua matriz européia, pontuando, dessa maneira, uma suposta superioridade do arquipélago com relação a outras colônias portuguesas no continente africano. A crença na democracia racial é um dos fatores que mais aproximaram Cabo Verde do Brasil ao longo da construção de um ideal de identidade nacional.

Martes (2000), a partir de um estudo sobre imigrantes brasileiros em Massachusetts, busca evidenciar os conflitos relacionados à identidade étnica, problematizando a etnicidade no campo das relações de poder como crucial na construção da identidade. Sendo assim, ela evidencia que a latinidade ou hispanicidade passa a ser um aspecto mais "preocupante" que o da identificação enquanto branco/a ou negro/a.

Por certo, "os brasileiros não afirmam uma identidade étnica propriamente, mas sim sua origem nacional" (MARTES, 2000, p.75). Isso acontece por dois fatores, segundo a autora, seja em relação à variável geracional ou à autoidentificação em que torna-se "vantajoso" autodenominar-se brasileiro ao invés de latino, em determinados momentos, assim como o contrário também pode acontecer.

Essa confusão parece ser bastante aceitável à condição dos brasileiros no exterior, uma vez que há um forte discurso de valorização do povo brasileiro como fruto de uma mistura étnicorracial, fortalecido pelo mito da democracia racial e, assim, demonstram uma dificuldade em se classificar racialmente quando abordados/situados num país - EUA - em que o binômio racial (preto e branco) é o predominante.

Em estudo sobre estudantes caboverdianos, Hirsch (2007) aponta que a inserção social determina a maneira como eles se classificam racialmente e torna-se um aspecto que contribui para a (re)construção de uma identidade negra e africana. Por certo, é perceptível a corporeidade identitária negra africana afirmativa nas/os estudantes, pautada nas vestimentas e penteados, por exemplo.

Não é incomum nas falas de muitos/as estudantes que entrevistamos o apontamento de que o fato de estarem em outro país, longe de suas famílias e costumes, os/as levaram a adotar uma postura mais crítico-reflexiva sobre seu estar 
no mundo, sobre as relações raciais com os/as brasileiros/as e sua identidade negra e africana e isso se apresenta na busca por uma valorização dos aspectos estéticos que remetem ao continente africano (GOMES, N. 2006).

Um fator que se apresenta de maneira recorrente na distinção entre ser estrangeiro além do vestuário, da alimentação em algumas situações, corresponde à fala, talvez o elemento mais evidente nessa diferenciação do "outro estrangeiro". A língua é um importante símbolo de representação da identidade, em foco africana e estrangeira, e é a partir dela que os/as estudantes africanos/as identificam-se entre si e entre pessoas externas por meio do sotaque que pode vir a ser motivo de preconceito e discriminação quando denominadas pela sociedade de acolhida como "enrolada", "estranha", "esquisita". A estudante E.S., angolana, observou que "os guineenses sofrem mais pela língua”, justamente por apresentarem variações fonéticas mais evidentes e distintas do português do que os angolanos, moçambicanos ou caboverdianos.

Para Raffestin (1993) a língua é um dos mais importantes meios de identidade de uma sociedade, sendo, inclusive, capaz de originar conflitos culturais entre sociedades. Ele analisa-a do ponto de vista das relações de poder e convencer-se de que ela não é apenas um instrumento, mas também exerce funções múltiplas de comunicação e transmissão do real. Assim,

Como tal, a língua é um recurso, um trunfo, e por consequência está no centro de relações que são, ipso fato, marcadas pelo poder. Certas línguas, tal como o inglês, por exemplo, ocupam espaços enormes e são de uso corrente, enquanto outras recuam e são de uso restrito, limitado a áreas relativamente pequenas (...). É que não se trata, apesar de tudo, de um problema linguístico, mas sim de uma questão de poder, de relações de poder e de estrutura de poder. (RAFFESTIN, 1993, p. 70).

Essa passagem é importante para lembrarmos o quanto a permanência do crioulo, língua falada em Guiné-Bissau e Cabo Verde, é encarada com estranheza e até inconformidade por muitos/as brasileiros/as. A diferença linguística neste caso é produto da resistência desse grupo social da mesma forma que a religião pode ser outro grupo.

O poder que a língua portuguesa exerce visa unificar, centralizar, homogeneizar grupos que vivenciam processos históricos distintos. Como lembra 
Raffestin (1993) "em toda política de integração e de unificação existe uma vontade de apagar as diferenças porque as resistências se engancham nessas diferenças, que são outros tantos obstáculos ao desenvolvimento de um poder total" (RAFFESTIN, 1993, p.75).

A imposição da língua portuguesa a Guiné-Bissau, Cabo Verde, Angola, Moçambique, por exemplo, é mais um fator que representa as estratégias de integração e dominação de Portugal sobre antigas colônias, mas que as populações resistem com mecanismos de fortalecimento de elementos culturais.

Além do aspecto linguístico, é importante lembrar que a noção de raça, um elemento que também representa o "outro" em sua diferença, tem uma dimensão espacial (RATTS, 2004). Léfèbvre (apud Corrêa, 2005) aponta para o fato de que 0 espaço é o lócus da reprodução das relações sociais de produção ou, em outras palavras, da sociedade. Santos, M. (1982) diz que "uma sociedade só se torna concreta através de seu espaço, do espaço que ela produz e, por outro lado, o espaço só é inteligível através da sociedade" (SANTOS, M., 1982, p. 26). Não é viável falar de sociedade sem falar de espaço e vice-versa, portanto, o espaço é mais que um reflexo social e sim um fator social.

Poderíamos considerar aqui a relação do/a migrante estudante africano/a com o espaço no sentido de atribuir a esse uma espécie de reflexo da maneira como sua corporeidade é lida/atribuída. Mais que considerarmos a categoria espaço no seu sentido absoluto, a intenção, quando referente a uma dada dimensão espacial das relações sociais refere-se à maneira como esta corporeidade assume importância nas marcas espaciais, além das formas arquitetônicas e paisagísticas, visto que o ser humano molda o espaço, imprime sua marca nele e sofre suas influências (RATTS, 2004).

O corpo negro, ao longo da história que conhecemos, em diversas partes do continente africano, também foi um elemento explorado e dominado na sua condição de mão-de-obra escrava, o que configurou uma representação social negativa presente nos dias de hoje ligada a uma noção de inferioridade, subalternização e promiscuidade. Até mesmo a referência aos espaços públicos como a rua esteve relacionada à corporeidade negra, à malandragem e à marginalidade e continuou mantendo uma analogia entre a desordem e a presença negra nos espaços públicos. A condição de migrante estudante africano em uma universidade brasileira traz à tona nossos pensamentos acerca do corpo negro estrangeiro, o "outro" lido a 
partir dos referenciais do "eu", das representações sociais que induzem a uma leitura de subalternidade e animalização, como ocorreu em 2012 na UNESP de Araraquara em São Paulo (figura1), quando alunos picharam muros da universidade com a frase "Sem cotas para os animais da África".

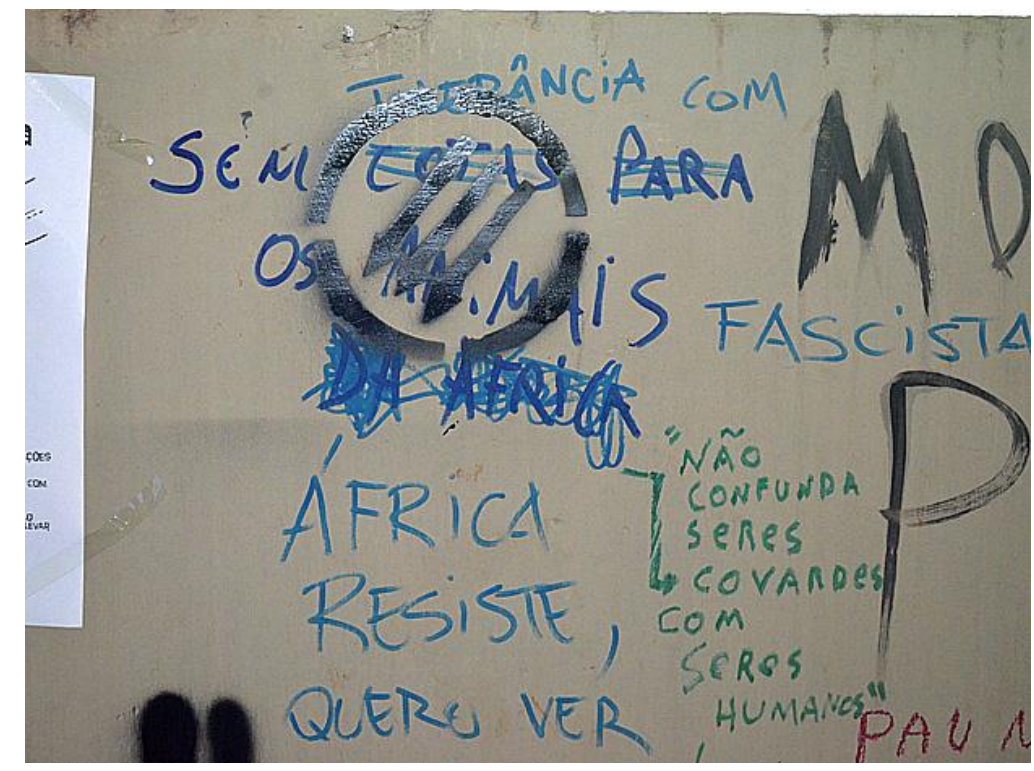

Figura 1: Pichação de cunho racista e xenofóbica encontrada na UNESP de Araraquara em São Paulo. Fonte: <http://www.g1.com.br>.

Acesso em: abr. de 2012.

Ser universitário e estrangeiro negro traz a experiência que representa descobrir-se em desvantagem social pela pigmentação da pele (SUBUHANA, 2005) e, no caso dos/as estudantes africanos/as essa problemática parece agravar-se a partir das associações representativas que o "eu brasileiro" remete ao continente africano como selvagem, miserável, bélico e doente, dentre outros adjetivos. Ocorre também uma espécie de generalização desses sujeitos em que todos/as são considerados africanos sem qualquer distinção de nacionalidade, ou que todos/as são príncipes e princesas munidos de forte posição social em seus países de origem.

O estudante H.A.M., 27 anos, de Moçambique relata que

(...)nunca encontrei um brasileiro, fora aqueles que já moraram por cá que saiba algo sobre Moçambique. Me espanta que até professores, que acredito serem pessoas com uma 'bagagem' intelectual maior, não sabem nem que este é um dos países que pertence à Comunidade dos Países de Língua Portuguesa, da qual o Brasil também faz parte" (H.A.M., 27 anos) 
(...) Colegas perguntam "muita gente da sua família passa fome? Usam roupas? Tem leão em casa? Alguns falam bem, despertam curiosidade em conhecer como é a realidade lá". (A., 23 anos)

(...) Geralmente os colegas não comentam sobre Cabo Verde. Eles pensam em África como um bloco hegemônico. Fazem perguntas generalizadas que nada tem a ver com a história de Cabo Verde. (J., 32 anos).

É inegável que em torno da idéia de raça ou do racialismo cria-se um conjunto de relações de poder cujo papel é hierarquizar lugares e pessoas de acordo com sua "evolução" e "desenvolvimento societário" que coloca em oposição natureza e cultura, como se América e África referissem-se à natureza, ao primitivo, e a Europa, estivesse ligada à noção de cultura próxima ao civilizado, ao racional (PORTOGONÇALVES, 2005).

Nesse sentido há um modelo de civilização construído que se torna parâmetro para classificar as demais formas de organização social existentes e, fatalmente, estas são julgadas a partir dos referenciais estabelecidos por quem os cria. Podemos encaixar nessa análise a respeito da maneira como as pessoas enxergam os/as africanos/as o conceito de colonialidade do poder cunhado por Quijano (2005) que corresponde a uma hierarquização e dominação político-econômica e cultural branco ocidental. Significa que mesmo após o colonialismo permanecem as relações de poder no campo do simbólico e/ou cultural em que o individuo africano apresentase pelo olhar "colonizador/colonizado" como selvagem, pobre ou desconhece o "progresso" da vida urbana.

A estudante M.A.C, 18 anos, de Cabo Verde conta que gosta do Brasil e dos/as colegas brasileiros/as, são gentis com ela, são acolhedores/as, acha que não sofreu nenhum tipo de discriminação, mas perguntam - com ironia- se lá tem msn, facebook, se os grandes animais passeiam pelas cidades etc.

Mesmo que o racismo apresente atualmente formas mais sutis e difusas, a percepção dos negros como uma ameaça social, percepção que pode ser associada ao racismo mais tradicional e flagrante, perdura na sociedade. Machado (1994) traz uma importante contribuição a este aspecto na medida em que apresenta as faces e situações do racismo no quotidiano de imigrantes luso-africanos, pois, assim como observamos as situações vivenciadas e relatadas pelos/as estudantes, há no que 
ele chama de Portugal de hoje dois parâmetros que servem de ponto de partida para um entendimento, embora nebuloso, do racismo que assola populações migrantes, principalmente, no que tange ao recorte racial.

O primeiro parâmetro seria a extensa história da expansão colonial que culminou com uma "descolonização" tardia e turbulenta - ou o que Kurz (1992) vai chamar de modernização retardatária que atingiu as colônias e aqui nos referimos às colônias portuguesas. O segundo parâmetro, no caso especifico de Portugal, foi a entrada excessiva de imigrantes provenientes das ex-colônias a partir dos anos 1980.

O estudo sobre as relações sociais e raciais nas ex-colônias parte a priori dessa experiência colonial portuguesa, como nos referimos aos países africanos de língua portuguesa, em que do ponto de vista de nosso entendimento, reforça o enraizamento de olhares sobre imagens, engessamento de conceitos raciais e propagação de estereótipos construídos sobre os outros e sobre si próprios. Interessante notar que

as representações comuns que vêem a imigração como uma "ameaça", seja econômica, seja à segurança, não se referem, de facto, a toda a imigração, mas apenas àquela que, por várias razões, incluindo os traços fenotípicos dos seus protagonistas, se torna mais visível socialmente. Os migrantes oriundos da União Européia e de outros países ocidentais, apesar de representarem mais de $40 \%$ dos estrangeiros em Portugal, e de ocuparem, regra geral, posições profissionais, empresariais e sociais de destaque, nem por isso têm sido vítimas de preconceito ou discriminação. (MACHADO, 1994, p.03).

Vê-se que existe uma hierarquização da própria condição migrante em que aqueles provenientes de países africanos ou latinos são entendidos como ameaça, como lixo social conforme já pontuamos, passando por situações de preconceito e discriminação nas mais diversas instâncias da vida social. Foi recorrente na conversa e contato com os/as estudantes a assertiva de que o racismo existe, mas não representa um incidente grave ou recorrente em suas vivencias cotidianas, alguns/mas preferem denominar "constrangimento", "situação de discriminação", mas não por causa da cor da pele. De acordo com J., 32 anos "não posso afirmar [que existe racismo no Brasil] por conhecer pouco, mas por aqui nunca senti racismo, mas às vezes por falar diferente há uma situação estigmatizante”. A estudante A. 23 anos, afirma "nunca sofri racismo. Só constrangimento". 
No teor destas afirmações, talvez nos levemos a pensar na maneira como estes/as estudantes passam por situações de "discriminação sofisticada" (SANTOS, H., 2002) sem notá-las. De acordo com Santos, H., (2002) o individuo que passa por esse tipo de discriminação raramente consegue perceber o fato e se assemelha àquela pela qual a chamada classe média negra brasileira enfrenta. Assim, em consonância com Subuhana (2007), o que se nota é o reconhecimento de que "o ser universitário e estrangeiro atenua a experiência negativa que representa descobrirse em desvantagem social pela simples pigmentação da pele" (SUBUHANA, 2007, p.331)

Por conseguinte, outros/as estudantes não hesitaram em afirmar que o Brasil é um país racista ou que já passaram por situações de discriminação racial, direta ou indiretamente e isso torna-se um agravante quando junto à condição de estrangeiro/a.

(...) Somos respeitados pela minoria acadêmica, mas não no ponto de ônibus, nos hospitais... pensam que a gente vem ocupar o lugar do brasileiro. (E.S. )

O Brasil é um país um pouco racista. Ouço muita queixa sobre o preconceito contra os negros. (D.M.M., 19 anos, caboverdiana)

O Brasil é um país racista, tanto no nível social, racial, religioso, geográfico e lingüístico (J.D.A.)

Mesmo que as pessoas neguem não tem como esconder que são racistas. Já presenciei atos de racismo até mesmo na universidade (J.M.L)

Aqui o racismo é muito camuflado (A.P.M.)

Racismo tem em todo o mundo (M.A.C.)

Se eu não conhecesse textos, não tivesse lido, ouvido falar de alguns casos, diria que o Brasil não é racista, porque eu nunca sofri racismo assim entre aspas, né? O que eu sofri tem mais a ver com exclusão por ser estrangeira, mas os meninos [outros colegas africanos homens] já passaram por situações de racismo. (E.S.)

Essa gama de relatos dos estudantes expressa a complexidade das tensões raciais existentes no âmbito da vivência de cada um e no entendimento que eles têm do fenômeno do racismo na sociedade brasileira na condição de "outro" e como isso os afeta. Por sua vez, a percepção sobre ser estrangeiro/a e ser negro/a muitas vezes se entrelaça numa simbiose que parece confundi-los ou representar 
sentimentos e expressões semelhantes. Para a estudante E.S., por exemplo, em seu relato, ser estrangeira - seja pelo problema da língua, da competitividade com brasileiros/as na graduação, da sensação de estar "de fora", ter poucas relações de amizade - parece ser mais oneroso que ser negra, de fato, são dois pesos que, infelizmente, não se pode ignorar ou relevar. Mas tanto o fato de ser estrangeira quanto ser negra representa uma condição de exclusão ou "marginalização" capaz de afetar a maneira como estes/as estudantes lêem suas relações com os/as brasileiros e com a própria universidade.

Outro aspecto que consideramos inadiável na consideração sobre a discriminação racial vivenciada pelos/as estudantes em questão refere-se às relações de gênero. Embora não seja um elemento crucial para a discussão neste trabalho, apesar de já termos buscado focar numa análise que buscou trazer o gênero em sua dimensão espacial (SOUZA, 2007) do ponto de vista da Geografia, a questão de gênero não pode estar ausente nessa discussão, pois ela se fez presente a todo momento, principalmente em relatos ricos de observação a respeito da desigualdade de gênero, na maneira como homens e mulheres são tratados/as e lidos/as nas mais diferentes situações.

De acordo com Hirsch (2009) se a discriminação na sociedade de acolhida era algo que os estudantes cabo-verdianos e estudantes africanos em geral desconheciam, para os rapazes, no entanto, ela foi rapidamente constatada, visto que freqüentemente eles se tornavam alvos de blitz da polícia, eram abordados por policiais armados em ônibus, táxis ou mesmo a pé. No entanto, as caboverdianas entrevistadas pela autora não se viam envolvidas nesse tipo de abordagem. Para elas,

(...) as maiores reclamações vêm das experiências vividas em shoppings e centros comerciais, onde não costumam receber 0 tratamento esperado por parte das atendentes. Em relação a esses ambientes, nos depoimentos dos rapazes há queixas sobre o comportamento de seguranças que costumam seguilos nas lojas, além de constrangimentos no momento de pagar a compra, quando são solicitados documentos adicionais, o que verificam não ocorrer com os demais clientes". (HIRSCH, 2009, p.72).

Como bem lembra a estudante E.S., angolana, é inegável que os jovens africanos passam cotidianamente por situações de estranhamento pela sua 
condição negra e estrangeira e, principalmente, por freqüentarem mais o espaço público do que as jovens africanas. Nas conversas com as meninas, percebeu-se um certo acanhamento ou discrição no jeito de falar, muitas, no início, não se aproximavam muito talvez por, a priori, fazerem uma leitura estereotipada das mulheres brasileiras, o que demonstrava pouco interesse em conversar ou "fazer amizade" fora do círculo das mulheres africanas.

Muitas vezes, as amizades e a convivência ficavam restritas entre as conterrâneas, bem como se observava uma falta de interesse de jovens brasileiras em se aproximarem ou se relacionarem. O momento em que havia maior contato era nas oficinas de trança realizadas durante o evento intitulado "Semana da África" organizada pelos/as estudantes africanos/as em toda ultima semana de maio. Assim, as brasileiras demonstram interesse em terem seus cabelos trançados, mas não se preocupam em estabelecer relações de troca e integração social com as jovens africanas, mesmo que o evento tenha este caráter da troca e participação de estudantes africanos/as e brasileiros/as.

Em todas as semanas que presenciamos, ficou a queixa dos/as estudantes africanos/as por não visualizarem uma participação significativa dos/as colegas brasileiros/as estudantes, dos representantes da própria universidade e dos/as próprios/as colegas africanos/as que, muitas vezes, precisam se desdobrar para conseguirem cumprir o cronograma dos cursos de graduação com aulas distribuídas em vários períodos.

O fato é que uma jovem estudante, migrante, negra, africana carrega em sua corporeidade as impressões de uma sociedade que a lê conforme suas convicções. Ela está exposta ao que chamamos de tripla discriminação, termo já utilizado por Carneiro (2004), por ser negra, por ser mulher e por ser migrante/estrangeira, passa por situações que, obviamente os jovens africanos não passam e vice-versa, como já nos referimos às abordagens policiais. Muitas vezes, essas jovens optam pelo silêncio diante das situações constrangedoras ocorridas dentro ou fora da universidade. Muitas vezes, existe uma intenção de questionar o racismo, verbalizar, refletir sobre isso, mas nem sempre há oportunidades para fazê-lo. Como nos disse E.S., angolana

Nós até poderíamos fazer algo [contra o racismo], mas nem sempre temos aquela força, aquele apoio. Quando aquela estudante angolana foi morta, eu fiz uma matéria, falei com minha professora que iria apresentar isso, houve um debate lá, 
a minha professora nos orientou, mas ai eu comecei a me desmotivar e desisti... é complicado, eu teria que reivindicar alguns direitos nossos, exigir, sendo que eu sou estrangeira e eu não recebi o apoio de todos os angolanos e africanos em geral, eles diziam "não faça isso, estuda, termina, vai pra Angola trabalhar, vc é muito nova e tal". A gente cai nessa, no conformismo...(E.S.)

Nesse sentido, grande parte dos/as estudantes africanos/as acabam se isentando de qualquer discussão que se remeta à questão racial e/ou ao racismo na tentativa de evitarem transtornos e desgastes com a sociedade que "os acolhe". Como lembra E.S.,

(...)É difícil ir pra sua casa e dizer que você é uma péssima pessoa, eu morando na sua casa... Muitas vezes a gente enfrenta dificuldades, mas a gente prima pelo silêncio, tipo eu tô aqui, são apenas 4 anos, eu vou terminar e vou embora... fica sempre nesse pensamento "nossa, eu sei que eu sou estrangeira, mas daqui a pouco eu vou embora"... Falar do racismo brasileiro é complicado...(E.S.)

Nota-se que a temporariedade pode ser um elemento salvador para quem vivencia o racismo à brasileira e se sente mais confortável esperar o tempo passar para o retorno, sempre focando no objetivo maior que é terminar a graduação, se estabelecer profissionalmente em seu país, ou voltar para cursar uma pósgraduação ou, em casos mais esporádicos, ficar definitivamente no Brasil, constituir família e trabalhar. Tivemos contato com alguns estudantes que permaneceram em Goiânia e interior de Goiás casados - mesmo sem a união civil - com mulheres brasileiras, um casal de guineenses que teve uma filha em Goiânia e permaneceu aqui, além dos que começaram a dar aulas em escolas e faculdades após o término da pós-graduação. Mesmo que se trate de um fator incomum, é importante ressaltar que o retorno não é uma máxima inabalável.

Por vezes, tentamos falar com alguns desses estudantes, mas a recusa foi certa e o pouco contato com os/as demais estudantes em suas casas também foi um elemento que dificultou neste sentido. Não se sabe se há de fato uma ilegalidade, mas a condição de migrante estudante com pendências nos pareceu certa em alguns casos e os/as demais colegas se isentam de qualquer comentário a respeito de tais casos.

O PEC-G e PG estabelece uma política de retorno bem evidentes no documento que o rege. De acordo com a Cláusula 23 do protocolo celebrado pelo 
Ministério das Relações Exteriores e o Ministério da Educação e do Desporto de 1998 e vigente até hoje, "Após a colação de grau, o estudante-convênio deverá preparar-se para retornar a seu país de origem em período não superior a três meses". Importante lembrar também que a Secretaria de Ensino Superior juntamente com a Policia Federal devem ser informadas pelas instituições de ensino a respeito da relação dos alunos graduados com suas respectivas datas de colação de grau.

O manual do Programa de Estudante Convênio elaborado durante o governo do presidente brasileiro Fernando Henrique Cardoso ainda rege as normas gerais mantidas atualmente. Com relação ao visto temporário do/a estudante, evidencia-se a responsabilidade total do/a mesmo/a diante de sua (re)validação, todos os requerimentos para sua permanência devem ser providenciados com antecedência de 30 (trinta) dias e, caso não aconteça, fica estabelecida multa diária e condição de ilegalidade.

Ao/à estudante estrangeiro/a não há qualquer possibilidade de participação em manifestações e atividades de cunho político. Versa num dos itens de obrigações a serem cumpridas pelos/as estudantes o "não-envolvimento em questões políticas: como estrangeiro, o estudante-convênio não deverá se envolver em manifestações e/ou atividades de cunho político, sob pena de sofrer todas as sanções previstas na legislação brasileira" (MRE, 2013, p.29).

No entanto, muitos protestos foram organizados nos últimos 03(três) anos com a intenção de denunciar o racismo e a discriminação sofrida por estudantes africanos/as do PEC-G e PG em várias cidades do Brasil, além de chamar a atenção das autoridades, seja no âmbito do Ministério das Relações Exteriores ou das universidades receptoras, para que haja o reconhecimento da situação desfavorável que se encontra estes/as estudantes mesmo que haja acordos que os legalizam, que os legitimam enquanto acadêmicos/as no Brasil. Um exemplo forte disso é a carta-manifesto organizada pelos estudantes do PEC-G da Paraíba em 2012 em que - estudante representante Eduardo Fernandes endereça a indignação da comunidade estudantil africana ao embaixador de Cabo Verde no Brasil Dr. Daniel Pereira: 
"Ao Senhor Embaixador,

A Comunidade acadêmica residente em João Pessoa Paraíba, no âmbito do programa de estudantes de graduação PEC-G (...) reflete a situações recorrentes que implicam o bemestar coletivo dos estudantes, tendo em vista inúmeros casos desconfortantes já observados, conseqüência de atos racistas e/ou discriminatórios, perpetradas no decurso do tempo, que resultam em agressões, racismos, preconceitos, difamação ou ate morte, como se pode lucidar os casos do estudante Nigeriano em Maranhão, dos estudantes Congoleses em Porto Alegre, da estudante Guineense na Paraíba, da ameaça e do ateamento de fogo em residências dos estudantes africanos em Brasília, e a mais recente morte da estudante Angolana em São Paulo (...)

Situações essas, que nos deixam perplexos e induzidos a profunda reflexão, contrária a inércia ou omissão das autoridades competentes no julgamento dos casos. O que reforça, no conseguinte, o nosso "medo" em relação a radicalização de tais cenas, em decorrência da impunidade ou até mesmo da trivialidade da justiça local em relação à situações pró-eminentes.

Diante da tamanha insatisfação quanto aos atos supramencionados, nós estudantes deste programa PEC-G, decidimos convergir as vozes, no sentido de exortar as entidades diplomáticas e/ou representativas, a abraçarem a causa e a se manterem solidários e atentos a essa problemática, no propósito de interceder com recursos necessários, junto as autoridades competentes, com o intuito de salvaguardar vidas e de contribuir de forma inequívoca, para o estabelecimento do clima de paz, harmonia, civilidade e respeito mutuo entre os povos.

Contudo, embora haja certas situações eminentemente deturpadoras do bom convívio, protagonizadas de forma isolada, porém merecedoras da atenção, queremos ressaltar a nossa satisfação e gratidão em relação ao Brasil e povo Brasileiro, salientando a imperiosa necessidade da cooperação multilateral, nos moldes social, cultural, intelectual etc que nos é e sempre será bem-vindo.

A interação Brasil - Africa, sempre teve valores incontestáveis e profícuos de contornos inestimáveis em todas as suas dimensões, sem prejuízo das partes.

Espera-se que esta cooperação e interação seja cada vez mais frutífera em matéria de solidariedade, Direitos Humanos, cumplicidade e respeito mútuo e amor ao próximo. 
Desde já agradecemos a atenção de Vossa Senhoria, no cumprimento de suas atribuições" (AFROPRESS, 2012).

Desse modo, como se pode observar pelo manifesto acima, embora haja prescrito no Decreto em vigor referente aos direitos e deveres dos estudantes do PEC-G e PG a proibição em manifestações e atividades de cunho político, é possível constatar que estes/as estudantes não são/estão omissos à sua condição migrante, estrangeira e negra e, coletivamente, se organizam para que haja denúncia e demonstração da insatisfação diante da precariedade social que sua condição acarreta. No entanto, também buscam reforçar a importância dos acordos de cooperação educacional e dos ganhos que se mantiveram em seus países acerca da qualificação da força de trabalho jovem africana.

Não podemos considerar, como já foi dito anteriormente, os/as estudantes africanos/as como um grupo social homogêneo, embora, por ainda admitirmos que uma pesquisa acadêmica não dá conta da complexidade e riqueza das identidades em seu sentido subjetivo de individualidades e coletividades, seja nossa tarefa aqui nos debruçarmos sobre um grupo social que se apresenta como tal, mas valendo-se que atitudes e comportamentos correspondem a um universo muito particular que respeita as trajetórias sociais, culturais e estudantis de cada um e fazem parte da dissociação-valor que condiciona estes sujeitos à fetichização das relações sociais no sistema moderno produtor de mercadorias.

Seja em Mourão (2009), em Hirsch (2009), Fonseca (2009), Subuhana (2009), Desidério (2006), Mungoi (2006), Gusmão (2009) o que vemos é uma gama de estudantes africanos/as com experiências e vivências diferentes entre si, mas é inegável que possuem objetivos semelhantes quanto à qualificação, visões sobre o Brasil, percepções sobre o mundo acadêmico, sobre a condição de estrangeiro/a dentre outros aspectos. Portanto, quando dizemos da situação enquanto negro/a, estrangeiro/a, migrante e estudante podemos representar vagamente o que isso corresponde no olhar e análise do/a pesquisador/a brasileiro/a e das instituições que os "acolhem", mas há uma resistência oculta exercida por este grupo social, uma busca por reforçar o sentido de coletividade em cada um/a, o sentimento de pertencer a uma nação africana e não a um continente invisível e generalizante apesar de sua dimensão físico-territorial.

O que podemos destacar na complexidade do "viver" estudante migrante é o compromisso com a missão pessoal e institucional de retorno ao país natal para 
afirmar a sua contribuição como cidadão/ã embora não haja uma preocupação em questionar o que vem a ser essa concepção de cidadania. O cidadão do ponto de vista de sua identidade capitalística (FONSECA, D. 2000) está ancorado no consumo, na sua capacidade de corresponder às exigências do sistema mundo moderno colonial (PORTO-GONÇALVES; QUENTAL, 2012), de se qualificar e contribuir com o mercado de trabalho de seu país natal, ou seja, é a ênfase no modelo econômico de cidadania.

Notou-se que a maioria dos/as estudantes faz planos de voltarem ao Brasil após a finalização da graduação com vistas a cursarem a pós-graduação. Ainda é minúsculo o numero de estudantes que se encontram em Goiânia fazendo a pósgraduação, pois requer, além de depender dos trâmites burocráticos envolvendo o Ministério das Relações Exteriores e instituições de ensino superior, força de vontade e disponibilidade financeira para tal. Os/as estudantes de pós-graduação quase sempre já são professores de instituições de ensino em seus países e contam com uma bolsa da CAPES (Coordenação de Aperfeiçoamento de Pessoal de Nível Superior) ou da própria instituição que os liberaram.

O estudante H.A.M. de Moçambique, no momento cursava o doutorado em Goiânia e havia concluído seu mestrado em Brasília. Ao ser perguntado sobre financiamento para seu estudo, diz

(...)sou financiado pelo governo brasileiro através de um acordo que existe com o governo moçambicano. Acredito que é parte de uma compensação que o Brasil dá pelo legado histórico que une os países e recentemente pela exploração de biocombustíveis e recursos minerais que empresas brasileiras desenvolvem cá. A grande desvantagem é que essa bolsa não cobre os custos das pesquisas, pois sendo uma bolsa de intercâmbio, para mim, o lógico é que o estudante pudesse realizar uma pesquisa em seu país de modo a contribuir para a compreensão ou resolução de algum aspecto específico. Tenho que incorrer a valores pessoais para que isso aconteça. Mas a vantagem é que posso estudar e manter o meu trabalho e ascender de categoria na minha carreira de docente quando terminar.

Assim, o retorno é uma cláusula presente, tanto para os graduandos quanto para os pós-graduandos, eles/as estão cientes dessa condição e sabem dos benefícios que poderão ser alcançados com o cumprimento dos deveres impostos pelo programa. Para eles, é inegável que há regras claras a serem obedecidas e 
uma delas é a obrigatoriedade do retorno como uma maneira de ajudar no desenvolvimento do país. Segundo este estudante, no caso de Moçambique, houve uma diminuição na procura por cursos de graduação fora do país.

Subuhana (2009) afirma que o diploma universitário vem se tornando o principal passaporte de construção do futuro das jovens gerações, as famílias se mobilizam para terem um "doutor" em seu seio que trará uma possibilidade de ascensão social. Além desse fator, há os casos de estudantes de famílias abastadas que ocupam cargos de poder em seus países e almejam a continuidade destes ou o auxílio de seus/as filhos/as em outras atividades complementares.

Mas há uma contradição nesse ponto no sentido de que, a partir de alguns relatos, soubemos que muitos/as os/as estudantes filhos/as de classe média alta dos países em questão optam ou procuram por países de primeiro mundo como Austrália, Inglaterra, Estados Unidos e Portugal, mas nem sempre os critérios de seleção são compatíveis com o perfil dos mesmos.

Então o paradoxo entre a exigência pessoal e familiar e a exigência profissional com a qualificação da força de trabalho é um elemento para reflexão, visto que a condição do/a migrante estudante é marcada pelas expectativas traçadas, aos objetivos a serem alcançados após a formação no ensino superior. Após a graduação, fica a dúvida sobre a continuidade dos estudos, sobre o retorno ao país como profissional ou a permanência no Brasil. Alguns/as estudantes relataram que pretendem continuar a pós-graduação no Brasil novamente, onde já estabeleceram vínculos e amizades, outros/as afirmaram que preferem "ganhar dinheiro" primeiro para depois voltarem para a pós-graduação.

A construção da identidade migrante, estudante e negra na corrida pela qualificação da força de trabalho representa os conflitos e contradições do sistema moderno produtor de mercadorias em que o estabelecimento de convênios e acordos entre Estados-nações modernos retardatários representa interesses econômicos e políticos que se travestem nos processos de individualização destes migrantes. A crença na melhoria da qualidade de vida, a busca por bons empregos, a futura contribuição para o desenvolvimento de seus países mesclam-se com as expectativas de morar fora, de conhecer outros horizontes, de se deparararem com as representações sociais sobre o Brasil, com a experiência de ser negro/a estrangeiro/ para só assim criarem outras impressões a partir de suas vivências. 


\section{CONSIDERAÇÕES PARA NÃO FINALIZAR}

O propósito em compreender as migrações estudantis africanas, sobretudo acordadas nas relações comerciais dos PALOP, a partir de considerações sobre a problemática da qualificação da força de trabalho e, principalmente, do valordissociação como possibilidade teórica da crítica radical que imbrica também a noção de raça como elemento de debate, é por vezes, um percurso sinuoso e complexo.

Uma abordagem simplória da identidade racial, dos conflitos raciais que envolvem o migrante num sentido amplo é, por certo, mais comum no debate acadêmico das ciências sociais humanas como um todo e serviu de respaldo para nossa investigação, trazendo contribuições ricas sobre um universo que correspondeu às trajetórias já percorridas em termos de pesquisa. Mas a inquietação acerca da razão fetichizada do sujeito pesquisador que naturaliza o fenômeno migratório ou, por vezes, individualiza os motivos que as leva, trouxe-nos dúvidas por outros ângulos, trouxe-nos a necessidade de refletir sob o ponto de vista da crítica ao trabalho, da separação que se dá o que é valorizado no moderno sistema produtor de mercadorias e aquilo que é o pormenor, o não-convencional, a "filigrana".

Partir do que é considerado, muitas vezes, como filigrana para ajudar no entendimento de uma totalidade social a partir do fenômeno migratório estudantil é que se apresenta como o grande desafio deste trabalho. É o aporte teórico que nos lança num palco de variações categóricas que antes parecem tão destoantes e não comunicáveis, mas que, na verdade, enriquecem a compreensão sobre a migração estudantil africana.

Uma análise do processo histórico, social e concreto, entende que a dependência do desenvolvimento capitalista, o fluxo de dinheiro e mercadorias é uma referência inicial para se compreender o fenômeno migratório estudantil, na medida em que o ensino superior, através dos programas de cooperação educacional, também se configura nesta dependência do sistema moderno produtor de mercadorias, se mercadoriza e precisa atender a essa dinâmica de desenvolvimento.

Assim, cada vez mais veremos acordos de cooperação, disponibilidade do ensino superior a um maior número de pessoas, o aumento do número de 
universidades, o intercâmbio estudantil presente em universidades de diferentes tamanhos e esferas administrativas, mas não por uma constatação ou necessidade da democratização do ensino, mas sim dessa submissão a uma engrenagem maior e mais profunda que movimenta a economia global.

A educação formal exerce também a função de continuidade das relações de produção que atende ao fetiche do valor na forma mercadoria. A formação pode significar, assim, a preparação de indivíduos para o mercado de trabalho e o êxito de um país na concorrência global (CRIONI e DIAS, 2010). Tem-se "uma formação crescentemente fragmentada e utilitarista, que não permite uma visão além da aparência superficial das relações sociais. A formação emancipatória torna-se minimizada. O indivíduo competitivo, empreendedor, ordenado pelo mercado, é conclamado como modelo" (CRIONI e DIAS, 2010, p.04). Ao lançarmos a crítica à educação nos moldes da forma mercadoria, estamos duvidando da missão salvadora da educação, dos objetivos e da positividade proferida pelos acordos de cooperação que colocam Brasil e África num patamar da corrida pelo desenvolvimento e progresso.

A migração por si mesma também obedece à dinâmica deste sistema moderno, a mobilidade do trabalho obriga o/a trabalhador/ à liberdade negativa sob sua força de trabalho. Como pontua Heidemann (2010)

a migração não é um processo passível de ser explicado, a partir de si mesmo, não é um fenômeno de uma mudança meramente cultural, na qual se demonstra um novo caráter "nômade" ou até aquela "essência humana" propriamente nômade, como alguns filósofos pós-modernos afirmam. Portanto, a migração pode ser explicada apenas como fenômeno da história social concreta (2010, p.18).

Foi por este âmbito que buscamos estabelecer conexões entre a subjetividade do/a migrante e sua sujeição às exigências do processo de modernização que fetichiza suas escolhas e os condiciona a uma relação de dependência ao que se considera necessário ao progresso e desenvolvimento, à melhoria da qualidade de vida, bom emprego e contribuição social aos seus países. Nessa condição de sujeito sujeitado consideramos também as experiências individuais e sociais dos/as estudantes africanos/as diante de relações simbólicas carregadas de percepções sobre a discriminação racial vivenciada no Brasil, a 
reflexão diante da condição de estrangeiro/a negro/a que, até então, não parecia uma observação já existente.

A crítica fundamental do valor a partir da dissociação da noção de raça nos possibilitou refletir sobre o/a migrante estudante que se apóia em sua liberdade negativa para acreditar nos benefícios que a formação no ensino superior pode trazer no plano individual e coletivo. A compreensão da sua condição de migrante, estudante, negro/a e estrangeiro/a se apresenta como elementos em que a subjetividade mescla-se à objetividade inconsciente. 


\section{REFERENCIAS}

ADORNO, Theodor; HORKHEIMER, Max. Dialética do Esclarecimento: fragmentos filosóficos. Tradução de Guido Antônio de Almeida. Rio de Janeiro: Jorge Zahar Ed., 1985.

AFROPRESS. Africanos fazem protesto em João Pessoa. 11 jun. 2012. Disponível em: <http://www.afropress.com.>. Acesso em: jun. 2012.

ALENCASTRO, Luiz Felipe. 0 trato dos viventes: Formação do Brasil no Atlântico Sul. São Paulo: Cia. Das Letras, 2000. Pp.11-48.

ALVES, Vicente Eudes Lemos. Mobilização e modernização nos cerrados piauienses: formação territorial no Império do agronegócio. 2006. 320 f. Tese (Doutorado em Geografia Humana). Programa de Pós-Graduação em Geografia Humana-USP. São Paulo, 2006.

. Mobilidade do trabalho e reprodução do capital nos cerrados piauienses, Boletim Goiano de Geografia, Goiânia - Goiás, v. 24, n. 1-2 p. 43-53 jan./dez. 2004.

ALVES, Maria de Fátima Carvalho. Representações sociais e construção da identidade de caboverdianos no Rio de Janeiro: estudantes, imigrantes e descendentes. 2008. 125 f. Dissertação (Mestrado em Psicologia Social). Programa de Pós- Graduação em Psicologia Social da Universidade do Estado do Rio de Janeiro - UERJ. Rio de Janeiro, 2008.

AMORIM, Cassiano C. 0 uso do território brasileiro e as instituições de ensino superior. 2010. 335 f. Tese (Doutorado). Programa de Pós-Graduação em Geografia Humana. Universidade de São Paulo - USP. São Paulo, 2010.

ANDRIOLI, Antonio I. O lugar das ciências humanas na universidade. Revista Iberoamericana de Educación. Disponível em: <http://www.rieoei.org>. Acesso em: ago. de 2013.

ANTUNES, Ricardo. Os Sentidos do Trabalho: Ensaio sobre a Afirmação e a Negação do Trabalho. São Paulo: Ed. Boitempo, 2002.

APPIAH, Kwame A. Na casa de meu pai: a África na filosofia da cultura. Tradução: Vera Ribeiro; Revisão de tradução Fernando Rosa Ribeiro. RJ: Contraponto, 1997.

ARAUJO, Ângela Maria C.; FERREIRA, Verônica C. Relações de gênero e sindicatos no contexto da reestruturação produtiva. In: ROCHA, Maria Isabel B. (org ${ }^{\underline{a}}$.) Trabalho e gênero: mudanças, permanências e desafios. São Paulo: ed.34, 2000.

ARRAIS, Tadeu A. O território goiano: uma abordagem quase contemporânea do desenvolvimento regional. In: Encontros Nacionais da ANPUR- Associação Nacional 
de Pós-Graduação e Pesquisa em Planejamento urbano e regional, v.12, 2007,(S.I.). Anais ... (S.I.). p.01-20.

BAUNGARTEN, M. "Comunidades ou coletividades? O fazer científico na era da informação". Política e Sociedade. Revista de Sociologia Política. Programa de Pós-Graduação em Sociologia Política. Florianópolis: Cidade Futura/UFSC, n.ำ 4, abr. 2004, p. 97-136.

BHABHA, Homi K. O local da cultura. Belo Horizonte: Ed. da UFMG, 1998.

BECKER, Olga Maria S. Mobilidade espacial da população: conceitos, tipologia, contextos. In: CASTRO, Iná E. de.; GOMES, Paulo César da C.; CORREA, Roberto L. (Orgs.). Explorações geográficas. Rio de Janeiro: Bertrand Brasil, 1997.

BÓGUS, L.M.M. e BASSANEZI, M.S.B. - Do Brasil para a Europa - Imigrantes Brasileiros na Península Itálica neste final de Século. In: SPM; CEM; CNBB; USP; CSEM (Orgs.). O Fenômeno Migratório no Limiar do 3ํMilênio, Rio de Janeiro, Vozes, 1998, p. 68-92.

BRAH, Avtar. Diferença, diversidade, diferenciação. Cadernos Pagu, n.26, Campinas-SP, jan-jun. de 2006.

CALDERÓN, Adolfo I. Universidades mercantis. A institucionalização do mercado universitário em questão, São Paulo em perspectiva, vol.14, n.1, 2000, p.61-72.

CARNEIRO, Sueli. A mulher negra na sociedade brasileira: o papel do movimento feminista na luta anti-racista. In: MUNANGA, Kabengele (org.) História do negro no Brasil, vol.1. O negro na sociedade brasileira: resistência, participação, contribuição. Brasilia: Fundação Cultural Palmares/Minc. 2004, p.34.

CASTELLS, Manuel. O poder da identidade. Tradução: Klauss B. Gerhardt. São Paulo: Paz e Terra, 2008.

CASTRO, Regina Maria J. C. Expansão da educação superior privada no Brasil a partir da década de 1990: o caso da Faculdade Cambury de Goiânia-GO. 2004.167 f. Dissertação (Mestrado) Programa de Pós-Graduação em Educação. Pontifícia Universidade Católica de Goiás, 2004.

CATANI, Afrânio Mendes e OLIVEIRA, João Ferreira de. As políticas de diversificação da educação superior no Brasil: alterações no sistema e nas universidades públicas. In: SIGUISSARDI, Valdemar (org.). Educação superior: velhos e novos desafios. São Paulo: Xamã, 2000. p. 65.

CHAUÍ, Marilena. A universidade pública sob nova perspectiva, Revista Brasileira de Educação, n.24, set./out./Nov. 2003.

CLEMENTE, Claudelir C. Analisando territórios e laços sociais de pessoas que vivem em mobilidade internacional. In: IV Encontro Nacional Sobre Migração da ABEP, 2005, RJ. Anais...RJ, 16-18 de nov. 2005. 
CÓ, João Ribeiro B. As associações das comunidades migrantes em Portugal e a sua participação no desenvolvimento do país de origem: o caso guineense, socIUS Working Papers, SOCIUS - Centro de Investigação em Sociologia Económica e das Organizações - Instituto Superior de Economia e Gestão, Universidade Técnica de Lisboa, N.12, Lisboa, 2004. p. 02-21.

COMUNIDADE DE PAÍSES DE LÍNGUA PORTUGUESA - CPLP. Declaração Final. Lisboa, 2009. Disponível em: <http://www2.iict.pt.>. Acesso em: jan. 2010.

CORRÊA, Roberto L. Espaço: Um conceito-chave da Geografia. In: CASTRO, Iná E. de; GOMES, Paulo C. da C; CORRÊA, Roberto L. Geografia: conceitos e temas. RJ: Bertrand Brasil, 2005. p.15-48.

COSTA, Sérgio. Dois Atlânticos: teoria social, anti-racismo, cosmopolitismo. Belo Horizonte: Ed. da UFMG, 2006.

CRIONI, Renato; DIAS, Romualdo. Políticas de subjetivação no capitalismo contemporâneo: um estudo sobre as marcas do colapso e da desolução. Disponível em:<http:// www.poli.usp.br. Acesso em: 08 fev. 2010.

DÉBORD, Guy. A sociedade do espetáculo. Rio de Janeiro: Contraponto, 1997.

DEPARTE, Jason. Em um mundo em movimento, Cabo Verde tenta lidar com a migração global. The New York Times, New York. 01 ago. 2007. Disponível em:<http://www.casadasafricas.org.br>. Acesso em: 24 de maio de 2009

DESIDÉRIO, Edilma de Jesus. Migração internacional com fins de estudo: o caso dos africanos do Programa Convênio de Graduação de três universidades públicas do Rio de Janeiro. 2006. 220 f. Dissertação (Mestrado) Programa de Mestrado em Estudos Populacionais e Pesquisas Sociais- IBGE). Rio de Janeiro, 2006.

Migração e políticas de cooperação: fluxos entre Brasil e África. In: IV Encontro Nacional Sobre Migração da ABEP, 2005, RJ. Anais...RJ, 16-18 de nov. 2005.

DOURADO, Luiz F. A interiorização da educação superior e a privatização do público. Goiânia: Ed. da UFG, 2001.

DUPAS, Gilberto. O mito do progresso. São Paulo: Editora UNESP, 2006.

DUSSEL, Enrique. Europa, modernidade e eurocentrismo. In: LANDER, Edgardo (org) A colonialidade do saber: eurocentrismo e ciências sociais. Perspectivas latino-americanas. CLACSO: Ciudad Autónoma de Buenos Aires, Argentina, setembro 2005. Colección Sur Sur. pp.227-278.

ESTRANGEIROS NO BRASIL. Disponível em:<http://www.oestrangeiro.org.br> Acesso: em ago. 2013. 
FARIA, Margarida Lima de. Cooperação no âmbito do ensino superior: ser estudante angolano em universidades portuguesas, Pro-Posições, Campinas, v. 20, n. 1 (58), p. 45-63, jan./abr. 2009.

FARTES, Vera Lúcia B. O diálogo entre economia e educação como chave para entendimento da aquisição da qualificação, Caderno CRH, Salvador, n. 29, p. 209226, jul./dez. 1998.

FONSECA, Dagoberto José. A tripla perspectiva: a vinda, a permanência e a volta de estudantes angolanos no Brasil. Pro-Posições, Campinas, v. 20, n. 1 (58), p. 2344, jan./abr. 2009.

Corpos negros (i)maculados: Mulher, catolicismo e testemunho. 2000. Tese (Doutorado), Programa de Estudos Pós-graduados em Ciências Sociais. PUC São Paulo, São Paulo, 2000.

FONSECA, Gildette Soares. Espacialização das migrações temporárias de mirabelenses. In: XVII Encontro Nacional de Estudos Populacionais, ABEP, 2010, Caxambú - MG - Brasil. Anais... Caxambú.20-24 set. 2010.

FREYRE, Gilberto. O luso e o trópico (1961). São Paulo: É Realizações, 2010.

FRIGOTTO, Gaudêncio. Trabalho, educação e tecnologia: treinamento polivalente ou formação politécnica? In: SILVA, Tomás Tadeu da (org.). Trabalho, educação e prática social: Por uma teoria da formação humana. Porto Alegre: Artes médicas, 1991. p. 254-274.

GAUDEMAR, Jean Paul de. Mobilidade do trabalho e acumulação do Capital. Lisboa: Estampa, 1977.

GAZZOLA, Ana Lúcia A. Conhecimento e globalização. In: GAZZOLA, Ana Lúcia A.; ALMEIDA, Sandra G. (orgs.) Universidade: cooperação internacional e diversidade. Belo Horizonte: EdUFMG, 2006, pp. 49-54.

GENRO, Tarso. Universidade, cooperação internacional e diversidade. In: GAZZOLA, Ana Lúcia A.; ALMEIDA, Sandra G. (orgs.) Universidade: cooperação internacional e diversidade. Belo Horizonte: EdUFMG, 2006. p.15-20.

GILROY, Paul. O Atlântico Negro. Modernidade e dupla consciência. São Paulo, Rio de Janeiro: Ed. 34/Universidade Cândido Mendes - Centro de Estudos AfroAsiáticos, 2001.

Gomes, José Manuel S. Estudantes na terra dos outros: a experiência dos universitários angolanos da Universidade Federal de Minas Gerais-Brasil.2002. 172 f. Dissertação (Mestrado). Programa de Pós-Graduação em Educação - UFMG. Belo Horizonte, 2002.

GOMES, Nilma L. Sem perder a raiz: corpo e cabelo como símbolos da identidade negra. Belo Horizonte: Autêntica, 2006. 
GORENDER, Jacob. O escravismo colonial. São Paulo: Ática, 1980.

GOETTERT, Jones Dari. Gentes, migração e transitividade migratória. Espaço Plural, Ano X, № 20, 1ํ Semestre 2009, pp. 53-62.

GUIMARÃES, Antonio Sérgio. A modernidade negra. Texto apresentado e discutido na Reunião da ANPOCS, 2002, Caxambu. Anais... Caxambu: GT: Teoria social e Transformações Contemporâneas. 2002.

Raça e racismo no Brasil. In: Racismo e antirracismo no Brasil. São Paulo: Fundação de Apoio à Universidade de São Paulo. ed. 34, 1999. p. 21-70.

GUPTA, Akhil; FERGUSON, James. Mais além da "cultura": espaço, identidade e política da diferença. In: ARANTES, Antonio A. (Org.). O espaço da diferença. Campinas-SP: Papirus, 2000, p.31-49.

GUSMÃO, Neusa Maria. Dossiê Ensino Superior e circulação internacional de estudantes: os Palop no Brasil e em Portugal. Pro-Posições, Campinas, v. 20, n. 1 (58), p. 13-21, jan./abr. 2009.

n.10, 2008.

África e Brasil no mundo acadêmico - diálogos cruzados. Focus, Unicamp,

Trajetos Identitários e Negritude: jovens africanos no Brasil e em Portugal. Impulso. Piracicaba, ano 17, n. 43, p. 45-57, 2006.

HALL, Stuart. A identidade cultural na pós-modernidade. Tradução: Tomaz Tadeu da Silva e Guacira Lopes Louro. 11. ed. Rio de Janeiro: DP\&A, 2011.

HARVEY, David. A mobilidade do capital variável e da força de trabalho. Disponível em: <http://blog.controversia.com.br>. Acesso em: 12 out. 2009.

HAESBAERT, Rogério. O mito da desterritorialização: do "fim dos territórios" à multiterritorialidade. 4 ed. Rio de Janeiro: Bertrand Brasil, 2009.

; LIMONAD, Ester. O território em tempos de globalização, etc, espaço, tempo e crítica: Revista Eletrônica de Ciências Sociais Aplicadas, nº 2 (4), vol. 1, 15 de Agosto de 2007.

; PORTO-GONÇALVES, Carlos Walter. A nova des-ordem mundial. São Paulo: Editora UNESP, 2006.

HEIDEMANN, Heinz Dieter. Deslocamentos populacionais e mobilidade fictícia: a razão fetichizada do migrante e do seu pesquisador. In: SILVA, Sidney A. da (org.) Migrantes em contextos urbanos: uma abordagem interdisciplinar. Manaus: EDUA, 2010. p. 15-34.

Os migrantes e a crise da sociedade do trabalho: humilhação secundária, resistência e emancipação. In: SERVIÇO PASTORAL DOS MIGRANTES. Migrações: discriminação e alternativas. São Paulo: Paulinas, 2004. 
. O migrante da racionalização global. In: SERVIÇO PASTORAL DOS MIGRANTES et al. (Orgs.) O fenômeno migratório no limiar do 3ํo milênio: desafios pastorais. Petropólis-RJ: Vozes, 1998. pp. 15-18.

HERNANDEZ, Leila Leite. A África na sala de aula: visita à história contemporânea. São Paulo: Selo Negro, 2005.

HINTZEN, Percy C. Diáspora, globalização e políticas de identidade. In: SANTOS, Renato E. dos (Org.). Diversidade, espaço e relações raciais: o negro na Geografia do Brasil. Belo Horizonte: Autêntica, 2007. p.53-74.

HIRATA, Helena; HUMPHREY, Jonh. O emprego industrial feminino e a crise econômica brasileira. Revista de Economia Política. N.16, v.4, p.87-107, out./dez. de 1984.

HIRSCH, Olivia Nogueira. "A gente parece um camaleão": (Re)construções identitárias em grupo de estudantes cabo-verdianos no Rio de Janeiro. ProPosições, Campinas, v. 20, n. 1 (58), p. 65-81, jan./abr. 2009.

. "Hoje eu me sinto africana": Processos de (re)construção de identidades em um grupo de estudantes cabo-verdianos no Rio de Janeiro.2007. (Dissertação de mestrado) Programa de Pós-Graduação em Ciencias Sociais- Pontificia Universidade Católica do Rio de Janeiro. Rio de Janeiro, 2007.

HÖNER, Christian. O que é o valor? Da essência do capitalismo - uma introdução. Original em alemão, 2004. Disponível em: <http://obeco.planetaclix.pt.>. Acesso em: mai. 2009.

KI-ZERBO, Joseph. História da África Negra. v. 2. Publicações Europa-America. Mira-Sintra. Mem-Martins, 1999.

KURZ, Robert. A economia política da educação. Original em alemão, 2011. Disponível em: <http://obeco.planetaclix.pt.> Acesso em: mar. 2012.

- Bárbarie, migração e guerras de ordenamento mundial: Para uma caracterização da situação contemporânea da sociedade mundial. In: Serviço Pastoral dos Migrantes. (Org.). Travessias na desordem global - Fórum Social das Migrações. São Paulo: Paulinas, 2005.

Analfabetos secundários. Publicado na Folha de São Paulo, 11 de Abril de 2004, com o título $O$ efeito colateral da educação fantasma. Disponível em: <http://obeco.planetaclix.pt.> Acesso em: set. 2009.

Razão sangrenta: 20 teses contra o assim chamado lluminismo e os "valores ocidentais". Original em alemão, 2002. Disponível em: <http://obeco.planetaclix.pt>. Acesso em: ago. 2009. 
Dominação sem sujeito: sobre a superação de uma crítica social redutora. Original em alemão, 1993. Disponível em: <http://obeco.planetaclix.pt.>. Acesso em: ago. 2009.

- O colapso da modernização: da derrocada do socialismo de caserna à crise da economia mundial. Tradução: Karen Elsabe Barbosa. Rio de Janeiro: Paz e Terra, 1992.

LAMAS, Bruno. Apresentação do ensaio "O Valor é o Homem" de Roswitha Scholz e da teoria da dissociação-valor. Original em alemão, 2011. Disponível em: <http://obeco.planetaclix.pt.>. Acesso em: out. de 2012.

LANDER, Edgardo. Marxismo, eurocentrismo e colonialismo. In: BORON, Atilio; AMADEO, Javier; GONZÁLEZ, Sabrina (Orgs.). A teoria marxista hoje: problemas e perspectivas. Buenos Aires: Consejo Latinoamericano de Ciencias Sociales, 2006.

LIMA, Manoelita C.; CONTEL, Fabio B. Contextualização: aspectos históricos e conceituais. In: Internacionalização da educação superior: Nações ativas, nações passivas e a geopolitica do conhecimento. São Paulo: Alameda, 2011.

LIPOVETSKY, Gilles. A Era do Vazio: Ensaios sobre o individualismo contemporâneo. Tradução de Miguel Serras Pereira e Ana Luísa Faria. Lisboa: Ed: Relógio d'Água, 1989.

MACHADO, Fernando L. et al. Classes sociais e estudantes universitários: origens, oportunidades e orientações. Revista Crítica de Ciências Sociais. (S. I.) n. 66, p. 45-80, out. 2003.

. Luso-africanos em Portugal: Nas margens da etnicidade. Sociologia Problemas e Práticas, Lisboa, n. 16, p. 111-134, 1994. Disponível em: <http://sociologiaapp.iscte.pt>. Aceso em: jul. 2010.

MAGALHÃES, Nancy Alessio. Memórias de estudantes de Angola no brasil. Cadernos CERU, série 2, v. 19, n. 1, jun. 2008.

MARTES, Ana Cristina B. Raça e etnicidade- opções e constrangimentos. In: ; FLEISCHER, Soraya (Orgs.). Fronteiras cruzadas: etnicidade, gênero e redes sociais. São Paulo: Paz e Terra, 2003. p. 73-98.

- Brasileiros nos Estados Unidos: Um estudo sobre imigrantes em Massachusetts. São Paulo: Paz e Terra, 2000.

MARTINE, George. A Globalização inacabada: migrações internacionais e pobreza no século 21, São Paulo em Perspectiva, v. 19, n. 3, p. 3-22, jul./set. 2005.

MARTINS, José de S. O problema das migrações no limiar do terceiro milênio. In: Serviço Pastoral dos Migrantes et al. (Orgs.). O fenômeno migratório no limiar do terceiro milênio: Desafios pastorais. Petrópolis, RJ: Vozes, 1998. 
Não há terra para plantar neste verão. Petrópolis, RJ: Vozes, 1988.

MARX, Karl. A teoria moderna da colonização. In: O Capital: crítica da economia política. Livro Primeiro. O processo de produção do Capital. Vol.II. 17. ed. Rio de Janeiro: Civilização Brasileira, 2001.

O Capital. v.1, Livro I. Tradução de Régis Barbosa e Flávio R. Koth. São Paulo: Abril, 1985.

MOORE, Carlos. A África que incomoda: Sobre a problematização do legado africano no quotidiano brasileiro. Belo Horizonte: Nandyala, 2010.

Racismo e sociedade: Novas bases epistemológicas para entender o racismo. Belo Horizonte: Mazza Edições, 2007.

MOURÃO, Daniele E. Guiné-Bissau e Cabo Verde: Identidades e nacionalidades em construção. Pro-Posições, Campinas, v. 20, n. 1 (58), p. 83-101, jan./abr. 2009.

África "na pasajen": identidades e nacionalidades guineenses e caboverdianas.2006. 163 f. (Dissertação de mestrado). Programa de Pós-Graduação em Sociologia da Universidade Federal do Ceará, Fortaleza, 2006.

MINISTÉRIO DAS RELAÇÕES EXTERIORES. Manual do Programa de Estudante-Convênio de Graduação/Pós-Graduação. Disponível em: <http://www.dce.mre.gov.br>. Acesso em: fev. de 2010.

MUNGOI, Dulce Maria Domingos Chale. Alteridade e fluxos migratórios no "Atlântico negro": estudantes africanos no sul do Brasil. In: JARDIM, Denise F. (org.) Cartografias da imigração: interculturalidade e políticas públicas. Porto Alegre: Editora da UFRGS, 2007.p.189-216.

O "mito atlântico": relatando experiências singulares de mobilidade dos estudantes africanos em Porto Alegre no jogo de construção e (re)construção de suas identidades étnicas.2006. 207 f. (Dissertação de mestrado) Programa de PósGraduação em Antropologia Social, Universidade Federal do Rio Grande do Sul. Porto Alegre, 2006.

NASCIMENTO, Elisa Larkin (Org.). A matriz africana no mundo. São Paulo: Selo Negro, 2008. (Sankofa: matrizes africanas da cultura brasileira;1).

NGOUMANE, Yara Neusa. Estudantes moçambicanos em Belo Horizonte: uma discussão sobre a construção identitária e as redes de sociabilidade. 2010. $100 \mathrm{f}$. Dissertação (Mestrado em Antropologia Social). Programa de Pós-Graduação em Antropologia Social, Universidade Federal de São Carlos - UFSCar, 2010.

OCADA, Fábio Kazuo. Migração e trabalho no mundo contemporâneo: uma experiência acerca da migração dekassegui. Travessia- revista do migrante, São Paulo, ano XVI, n.45, janeiro-abril de 2003. 
OLIVEIRA, Aécio A. de; MOREIRA Carlos A. L.; MARQUES, Marcelo S. Crise estrutural do sistema do capital, dominação sem sujeito e financeirização da economia. In: V Colóquio do Cemarx, 2011, Campinas. Anais... Campinas, 2011. Disponível em: <http://www.unicamp.br/cemarx>. Acesso em: maio 2011.

OLIVEIRA, João F.; DOURADO, Luis F.; AMARAL, Nelson C. Expansão e qualidade da educação superior em Goiás. Disponível em: <http://www.redecaes.com.br>. Acesso em: mar. 2013.

OLIVEIRA, João F.de.; LEMOS, Jandernaide R. Acesso e expansão do ensino superior noturno em Goiás: perspectivas de democratização. Reflexão e Ação Revista do Departamento de Educação e do Programa de Pós-Graduação em Educação, Universidade de Santa Cruz do Sul, v.17, n.2, p. 26-48, 2009.

PAVARINO, Rosana Nantes. Teoria das Representações Sociais: pertinência para as pesquisas em comunicação de massa. In: XXVI Congresso Anual em Ciências da Comunicação, 2003, Belo Horizonte/MG. Anais... Belo Horizonte: 02 a 06 de setembro de 2003.

PENHA, Eli A. Relações Brasil-África e Geopolítica do Atlântico Sul. Salvador: EDUFBA, 2011.

PINTO, José Marcelino de R. O acesso à educação superior no Brasil, Educação e Sociedade, Campinas, vol. 25, n. 88, p. 727-756, Especial - Out. 2004.

PONTIFÍCIA UNIVERSIDADE CATÓLICA DE GOIÁS. Assessoria de Relações Internacionais. Disponível em: <http://www.pucgoias.edu.br. Acesso em: mar. 2010.

PORTO-GONÇALVES, C. Walter;QUENTAL,Pedro de Araújo. Colonialidade do poder e os desafios da integração regional na América Latina, Polis [En línea], 31|2012, Puesto en línea el 12 diciembre 2012. Disponível em: <http://polis.revues.org/3749>. Acesso em: 12 fev. 2013.

Apresentação da edição em português In: LANDER, Edgardo (org) A colonialidade do saber: eurocentrismo e ciências sociais. Perspectivas latinoamericanas. CLACSO: Ciudad Autónoma de Buenos Aires, Argentina, setembro 2005. Colección Sur Sur. p.03-06.

PÓVOA NETO, Helion; FERREIRA, Ademir Pacelli (Org.). Cruzando fronteiras disciplinares: Um panorama dos estudos migratórios. Rio de Janeiro: Revan, 2005.

p. 6-13, 2001.

[Entrevista] com Hélion Póvoa Neto. Formação, Presidente Prudente, n.8, . Migrações internas e mobilidade do trabalho no Brasil atual. Novos desafios para a análise. Experimental, n. 2, p. 11-24, mar., 1997.

QUIJANO, Aníbal. A colonialidade do poder. In: SANTOS, Renato E. dos (Org.). Diversidade, espaço e relações sociais: O negro na Geografia do Brasil. Belo Horizonte: Autêntica, 2007. p. 43-52. 
. Colonialidade do poder, eurocentrismo e América Latina. In: LANDER, Edgardo (Org.). A colonialidade do saber: eurocentrismo e ciências sociais. Perspectivas latino-americanas. CLACSO: Ciudad Autónoma de Buenos Aires, Argentina, setembro 2005. Colección Sur Sur. p.227-278.

RATTS, Alex. Geografia, relações étnico-raciais e educação: a dimensão espacial das políticas de ação afirmativa no ensino. Terra Livre, São Paulo, Ano 26, V.1, n. 34, p. 125-140. jan.-jun. 2010.

A linha do corpo negro desenhando o espaço. Revista Toques de Angola Instituto Nzinga, Brasília, n. 1, p. 26-27, nov. 2004.

RAFFESTIN, Claude. Por uma Geografia do Poder. Tradução: Maria Cecília França. São Paulo: Ática, 1993.

RIBEIRO, Cláudio Oliveira. Brasil-África: notas sobre política externa e comércio exterior (1985-2005), Afro-Ásia, Salvador-BA, n.35, p. 281-314. 2007.

RILKE, Rainer Maria. 1904. In: Cartas a um jovem poeta. Tradução de Pedro Süssekind. - Porto Alegre: L\&PM, 2009. 96 p.; 18 cm. (Coleção L\&PM Pocket Plus)

RODRIGUES, Nina. Os africanos no Brasil. 6. ed. São Paulo: Editora Nacional, 1982.

SAES, Décio. O Estado escravista moderno no Brasil Pós-Colonial (1831-1888). In: A formação do Estado Burguês no Brasil (1888-1891). 2. ed. Rio de Janeiro: Paz e Terra, 1985.

SALIM, Celso A. "Migração: o Fato e a Controvérsia Teórica". In: VIII Encontro Nacional de Estudos Populacionais. 1992, São Paulo. Anais... v. 3, São Paulo: ABEP, 1992. p.119-144.

SANTOS, Boaventura S.; FILHO, Naomar de A. A universidade no século XXI: para uma universidade nova. Coimbra: [s. n.], 2008.

SANTOS, Hélio. Negro não é problema, é solução [Entrevista]. Caros Amigos. São Paulo, ano 6, n. 69, p. 31-37, 2002.

SANTOS, Ivair A. A. dos. O racismo institucional. Brasília: FCP, 2012.

SANTOS, Milton Por uma outra globalização: do pensamento único à consciência universal. Rio de Janeiro: Record, 2000.

Sociedade e espaço: A formação social como teoria e como método. In: Espaço e Sociedade: Ensaios. Petrópolis: Vozes, 1982. p. 09-22. 
SARAIVA, José F. S. A dimensão atlântica da política externa brasileira: Uma história de oportunidades latentes. 1996. Disponível em: <http://www.casadasafricas.org.br>. Acesso em: set. 2011.

. Do silencio à afirmação: As relações do Brasil com a África. In: CERVO, A. L. et al. (Orgs.). O desafio internacional. Brasilia: UnB, 1994.

SAYAD, Abdelmalek. O retorno: Elemento constitutivo da condição do imigrante. Travessia, São Paulo, ano XIII, número especial, p. 7-30, jan. 2000.

A imigração: ou os paradoxos da alteridade. Tradução Cristina Murachco. São Paulo: EdUSP, 1998.

SCHOLZ, Roswitha. O sexo do capitalismo. Teorias Feministas e Metamorfose Pós-Moderna do Patriarcado. Original em alemão, 2011. Disponível em: $<$ http://obeco.planetaclix.pt.>. Acesso em: ago. 2012.

Forma social e totalidade concreta: na urgência de um realismo dialéctico hoje. Original em alemão, 2009. Disponível em: <http://obeco.planetaclix.pt.> Acesso em: ago. 2010.

A nova crítica social e o problema das diferenças: disparidades econômicas, racismo e individualização pós-moderna. Algumas teses sobre o valordissociação na era da globalização. Original em alemão, 2004. Disponível em: <http://obeco.planetaclix.pt.>. Acesso em: ago. 2010.

O valor é o homem. Teses sobre a socialização pelo valor e a relação entre os sexos. Original em alemão, 1992. Disponível em: <http://obeco.planetaclix.pt.>. Acesso em: ago. 2010.

SCHUTZER, Herbert. África subsaariana: a última fronteira do capitalismo. 2009. Disponível em: <http://www.mundorama.net>. Acesso em: mar. 2010.

SCHWARCZ, Lília M. O espetáculo das raças. Cientistas, instituições e questão racial no Brasil, 1870-1930. São Paulo: Companhia das Letras, 1993.

SHIROMA, Eneida O.; CAMPOS, Roselane F. Qualificação e reestruturação produtiva: Um balanço das pesquisas em educação, Educação \& Sociedade, (S. I.), ano XVIII, n. 61, p. 13-35, dez. 1997.

SILVA, Izildo C. A. da. A mobilidade do trabalho sob o impacto da reestruturação produtiva: estudo das tendências migratórias em Santo André. 2008. 163 f. Dissertação (Mestrado) Programa de Pós-Graduação em Geografia Humana), Faculdade de Filosofia, Letras e Ciências Humanas da Universidade de São Paulo. São Paulo, 2008.

SILVA, Maria Aparecida de M. Contribuições metodológicas para a análise das migrações. In: DEMARTINI, Zeila de B. F.; TRUZZI, Oswaldo M. S. (Orgs.). Estudos migratórios: perspectivas metodológicas. São Carlos: EdUFSCar, 2005. p. 53-86. 
SILVA, Tomaz T. A nova direita e as transformações na pedagogia da política e na política da pedagogia. In: GENTILLI, Pablo A.A; SILVA Tomaz Tadeu da. (Orgs.). Neoliberalismo, qualidade total e educação. 7. ed. Petrópolis: Vozes, 1999.

SILVA, Yara F. de O. e; REIS, Marlene B. de F. Educação superior no estado de goiás: desafios e limites. In: Simpósio da ANPAE. 2011(S. I.). Anais eletrônicos... (S. I.), 2011. Disponível em:<http://www.anpae.org.br.> Acesso em: dez. 2011.

SOUZA, Lorena F. de. Relações de Poder, Mídia e Discriminação: Os Espaços Não Ocupados pela Mulher Negra nas Revistas Femininas. In: VII Fazendo Gênero, 2008, Florianópolis. Anais ...Florianópolis-SC, 2008.

Corpos negros femininos em movimento: Trajetórias socioespaciais de professoras negras em escola públicas. 2007. 126 f. Dissertação (Mestrado) Programa de Pós-graduação em Geografia. Instituto de Estudos Socioambientais, Universidade Federal de Goiás, Goiânia, 2007.

SUBUHANA, Carlos. A experiência sociocultural de universitários da África lusófona no Brasil: Entremeando histórias. Pro-Posições, Campinas, v. 20, n. 1 (58), p.103126, jan./abr. 2009.

. Estudantes moçambicanos no Rio de Janeiro, Brasil: Sociabilidade e redes sociais. Imaginário - USP, v. 13, n. 14, p. 321-355. 2007.

Estudar no Brasil: imigração temporária de estudantes moçambicanos no Rio de Janeiro. 2005. 211 f. Tese (Doutorado) em Serviço Social- Programa de PósGraduação em Serviço Social- Universidade Federal do Rio de Janeiro. Rio de Janeiro, 2005.

SUERTEGARAY, Dirce Maria. Geografia contemporânea movimento e crítica. In: MENDONÇA, Francisco de A.; LOWEN-SAHR, Luiza, SILVA, Márcia da (orgs.) Espaço e tempo: complexidade e desafios do pensar e do fazer geográfico. Curitiba: ADEMADAN, 2009. p. 107-120.

TANNURI, Maria Regina P. Refugiados congoleses no Rio de Janeiro e dinâmicas de "integração local": Das ações institucionais e políticas públicas aos recursos relacionais das redes sociais. $2010218 \mathrm{f}$. Tese (doutorado), Instituto de Pesquisa e Planejamento Urbano e Regional, Universidade Federal do Rio de Janeiro, Rio de Janeiro, 2010.

THOMAZ JÚNIOR, Antônio. Por trás dos canaviais os "nós" da cana (A relação capital $\mathrm{X}$ trabalho e o movimento sindical dos trabalhadores na agroindústria canavieira paulista). São Paulo: Annablume/Fapesp, 2002.

TOLEDO, Carlos de Almeida. A região das Lavras baianas. 2008. 248 f. Tese (Doutorado em Geografia Humana), Faculdade de Filosofia, Letras e Ciências Humanas - USP. São Paulo: 2008. 
UNIVERSIDADE ESTADUAL DE GOIÁS. Funções docentes por grau de formação (1999-2012) - Gerencia de Avaliação Institucional. Disponível em: <http://www.cdn.ueg.br.> Acesso em: nov. 2012.

UNIVERSIDADE FEDERAL DE GOIÁS. UFG em números - 2010. Pró-reitoria de Desenvolvimento Institucional e Recursos Humanos. Coordenação e organização Everton Wirbitzki da Silveira. Goiânia: UFG, 2010.

VAINER, Carlos. Reflexões sobre o poder de mobilizar e imobilizar na contemporaneidade. In: PÓVOA NETO, Hélion; FERREIRA, Ademir P. (Orgs.). Cruzando fronteiras disciplinares: Um panorama dos estudos migratórios. Rio de Janeiro: Revan, 2005, p. 231-274.

VARGEM, Alex A. A Política Externa Brasileira para a África no Governo Lula, Ponto-e-vírgula, n.4, p.06-11. 2008. 
APÊNDICE - Roteiro de entrevista

Nome completo

Estado civil:

Idade:

Sexo:

Profissão (ocupações anteriores/ se já tem uma formação):

País de origem (cidade ou campo, região, província):

Formação educacional no país de origem ou em outros países antes de chegar ao

Brasil-

Graduação

Pos-graduação

1- Por que escolheu o Brasil para o estudo?

2- Chegou a escolher outro país, a concorrer a uma bolsa em outro país?

3- Já quis estudar em outro país?

4- Por que ir em um país periférico (Brasil) e não em países centrais?

5- Por que escolheu São Paulo ou Goiás ou Brasília ou Rio de Janeiro?

6- Como imaginava o Brasil antes de sua chegada?

7- Quais os cursos mais procurados?(pelo censo)

8- Financiamento dos pais, de ONGs, do próprio país e de outros países (vantagens, desvantagens e suas diferenças)

9- Financiador da bolsa de estudos (com quais projetos financiadores veio para o Brasil? O que o financiador esperar de vc?)

10-Como tem sido feita a seleção para concorrer a uma bolsa de estudos para o Brasil em seu país? Há uma transparência ou privilégio partidário, lingüístico e/ou regional? 
11-O que pensa sobre (Quais eram/são) as intenções do financiador da bolsa de estudos?

12-Quais eram seus projetos de vida antes de sua vinda ao Brasil?

13-Quais são as afinidades entre o Brasil e o seu país?

14-O que vc ouve os brasileiros comentarem sobre vcs?

15-Quem são os brasileiros para você?

16-O Brasil é um país racista?

17-Vc considera o Brasil uma terra de brancos?

18-Você vê diferença de tratamento entre negros de nacionalidades diferentes? Como é que são vistos e diferenciados no Brasil?

19-Em que situações vc é negro/estrangeiro?

20-Vc acha que escolheria o Brasil para prosseguir seus estudos, após a graduação? 
ANEXO - Termo de responsabilidade financeira para inscrição no PEC

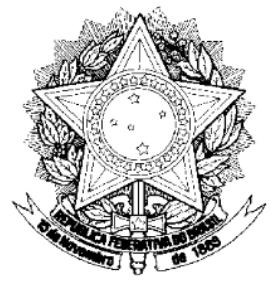

\section{República Federativa do Brasil posto (sobrescrever aqui)}

\section{Termo de Responsabilidade Financeira para Inscrição}

Eu, [nome], [nacionalidade], [estado civil], [profissão], nascido(a) a [dia/mês/ano] em [cidade, estado, país], residente e domiciliado(a) em [endereço], afirmo, para fins de inscrição no processo seletivo do Programa de EstudantesConvênio de Graduação - PEC-G 2013, que assumo inteira responsabilidade pela manutenção de caso venha a ser

selecionado(a) pelo referido processo seletivo, pagando seu bilhete de passagem aérea de ida e volta, instalação inicial, e o equivalente a US\$ ,00 ( dólares norte-americanos)

mensais, durante sua estada no Brasil, pelo período do curso.

Declaro, outrossim, que recebo o equivalente a US\$ , 00 dólares norte-americanos) mensais, de forma que poderei honrar este compromisso.

Telefone(s) para contato: Fax: e-mail: de de 2012.

\section{(Assinatura do responsável financeiro do estudante)}

Anexar quaisquer outros documentos relevantes para comprovar as informações acima, bem como para atender aos requisitos exigidos pela Missão diplomática brasileira. Referências a valores monetários nesses documentos anexados deverão ser convertidas para reais ou para dólares norte-americanos, informando a taxa de conversão. 
